University of Rhode Island

DigitalCommons@URI

Open Access Master's Theses

2017

\title{
Environmental Impacts of Oyster Aquaculture on the Coastal Lagoons of Southern Rhode Island
}

Chelsea Elizabeth Duball

University of Rhode Island, chelsea_duball@my.uri.edu

Follow this and additional works at: https://digitalcommons.uri.edu/theses

\section{Recommended Citation}

Duball, Chelsea Elizabeth, "Environmental Impacts of Oyster Aquaculture on the Coastal Lagoons of Southern Rhode Island" (2017). Open Access Master's Theses. Paper 1031.

https://digitalcommons.uri.edu/theses/1031

This Thesis is brought to you for free and open access by DigitalCommons@URI. It has been accepted for inclusion in Open Access Master's Theses by an authorized administrator of DigitalCommons@URI. For more information, please contact digitalcommons@etal.uri.edu. 
ENVIRONMENTAL IMPACTS OF OYSTER AQUACULTURE ON THE

COASTAL LAGOONS OF SOUTHERN RHODE ISLAND

BY

CHELSEA ELIZABETH DUBALL

A THESIS SUBMITTED IN PARTIAL FULFILLMENT OF THE REQUIREMENTS FOR THE DEGREE OF

MASTER OF SCIENCE

IN

BIOLOGICAL AND ENVIRONMENTAL SCIENCES

UNIVERSITY OF RHODE ISLAND

2017 
MASTER OF SCIENCE THESIS

OF

CHELSEA ELIZABETH DUBALL

APPROVED:

Thesis Committee:

Major Professor

Mark Stolt

Jose Amador

Candace Oviatt

Nasser H. Zawia

DEAN OF THE GRADUATE SCHOOL

UNIVERSITY OF RHODE ISLAND

2017 


\begin{abstract}
Coastal lagoons are shallow estuarine systems which hold significant ecological and economic value to Rhode Island and its coastal communities. As the land around these coastal lagoons has been developed, excess inputs of nitrogen $(\mathrm{N})$ from anthropogenic activity have entered the ecosystems. These inputs have resulted in eutrophication, leading to loss of ecosystem services and poor water quality. Oyster aquaculture has the potential to reduce $\mathrm{N}$ inputs via filter-feeding, helping to maintain water quality and ecosystem services.
\end{abstract}

In this study, I monitored water quality within aquaculture and control sites in three coastal lagoons located in southern Rhode Island, to assess the effectiveness of cultured-oysters to maintain water quality. I measured water temperature, $\mathrm{pH}$, salinity, chlorophyll (chl) $a$, dissolved oxygen, total suspended solids, ammonium, nitrate, and soil pore-water sulfides at both aquaculture and control sites. With the exception of chl $a$ and soil pore-water sulfides, oyster aquaculture had no significant effects on the water quality parameters. Aquaculture areas had significant lower chl $a$ levels, suggesting oysters improve water quality by filtering phytoplankton from the water column. The increase in sulfides in the pore-water suggests that oyster biodeposits also alter the pore-water chemistry in the soil.

To further our understanding on the impacts of biodeposits on the benthic environment, I measured changes to the soils at different magnitudes of oyster biodeposition. Oyster biodeposition rates ranged from 0.10 to $0.64 \mathrm{~g}$ DW oyster ${ }^{-1} \mathrm{day}^{-}$ ${ }^{1}$, or 68.86 to $346.47 \mathrm{~g} \mathrm{DW} \mathrm{m}^{-2} \mathrm{day}^{-1}$, whereby higher densities and larger oysters produced more biodeposits. I applied one week's worth of biodeposits representing a 
control (no oysters), an average stocking density $\left(500\right.$ oysters $\left.\mathrm{m}^{-2}\right)$, and a high stocking density (2000 oysters $\mathrm{m}^{-2}$ ) to the soil surface to monitor changes in soil $\mathrm{N}$ and $\mathrm{C}$ levels from biodeposits over a one-week period. I found that no significant enrichment of either $\mathrm{N}$ or $\mathrm{C}$ occurred within the soils - even at the highest oyster density suggesting that the microbial and benthic community can process considerable amounts of biodeposit-derived $\mathrm{N}\left(5.4 \mathrm{~g} \mathrm{~m}^{-2}\right)$ and $\mathrm{C}\left(44.3 \mathrm{~g} \mathrm{~m}^{-2}\right)$ in a short time.

To assess the long-term impacts of biodeposits and aquaculture practices on the benthic environment, I inventoried resident benthic infauna and measured particle size distribution, electrical conductivity, bulk density, total N, total C, and incubation $\mathrm{pH}$ of soils that supported aquaculture from 0 (control) to 21 years. Significant differences were observed in soil properties among aquaculture sites and control sites, but none of the differences were clearly associated with the number of years the soils supported aquaculture. Total abundance of infauna, deposit feeder populations, interface feeder populations, and parasite populations were significantly different across sites, with the 8-and 12-year aquaculture sites having significantly higher abundance of infauna compared to the control. All aquaculture sites $>5$ years-old had higher abundance of deposit feeders than the control sites. The majority of infauna at aquaculture sites were opportunistic species (Capitella capitata and Corophium volutator), which are indicative of disturbed areas. There was no significant correlation between total abundance of infauna and $\mathrm{N}$ and $\mathrm{C}$ pools, bulk density, or change in incubation $\mathrm{pH}$ (soil sulfides levels). These results suggest the effects of oyster aquaculture on soil properties and infauna are likely driven by site specific impacts of aquaculture, rather than being directly related to time in aquaculture. 
My findings show that oyster aquaculture has a significant impact on both the water column and benthic environments. While oysters help to maintain water quality by controlling phytoplankton levels, this activity increases biodepositional inputs, rich in $\mathrm{N}$ and $\mathrm{C}$, to the benthic environment. Our biodeposit application study suggested that the microbial and benthic communities within the upper $2 \mathrm{~cm}$ of soil could process high amounts of biodeposits over a short time frame. Our long-term study suggested increased levels of $\mathrm{N}$ and $\mathrm{C}$ in the soil were not proportional to the age of aquaculture use, however, a majority of aquaculture sites had higher $\mathrm{N}$ and $\mathrm{C}$ levels between 5-20 cm, compared to the surface soils from 0-5 cm. Additionally, total infauna, deposit feeder, and interface feeder populations (dominated by opportunistic species) increased at aquaculture sites, regardless of age of aquaculture use. Results suggest there are minimal impacts to the soil properties, aside from the presence of hydrogen sulfides and $\mathrm{N}$ and $\mathrm{C}$ sequestration. While soil properties had no statistically significant effect on infauna, it is apparent that disturbances from aquaculture practices may lower the trophic quality of organisms, favoring high abundances of opportunistic species indicative of disturbance. Other ecological interactions that were not apparent in our analysis could help to explain the shift in trophic community structure; these include successional dynamics of specific species, predator-prey interactions, and sulfide tolerance levels. Together, the effects of biodeposition and aquaculture practices, increase total abundance of infauna, especially burrowing infauna, which could help to increase translocation of $\mathrm{N}$ and $\mathrm{C}$ deeper in the soil profile and enhance effects of bioturbation to the soil environment. 


\section{ACKNOWLEDGEMENTS}

This research was funded by research grants from the Rhode Island Sea Grant, and the Nature Conservancy's Global Marine Program. Additionally, this material is based upon work supported in part by the National Science Foundation EPSCoR Cooperative Agreement \#EPS-1004057. I am grateful for this support which has significantly enhanced my research.

I would like to thank my advisors, Dr. Jose Amador and Dr. Mark Stolt, for their guidance and support throughout the duration of this study, and for making my entire career at URI an enjoyable and fulfilling experience. I would also like to thank my additional committee member, Dr. Candace Oviatt, for her insight and cooperation. In addition, I would like to thank all of the aquaculture farmers and specialists who helped me throughout this project, including Dale Leavitt, Matthew Griffin, Perry Raso, Jim Arnoux, Jeffrey Gardner, and their helpful staff, without their knowledge and assistance this project would not be made possible.

I would also like to thank the undergraduate students who put so much hard work into this project: Brad Camiel, Ethan Sneesby, Jared Cianciola, Shannon Cron, Lauren Salisbury, and Annie Ragan- you truly were a pleasure to work with. Great thanks go out to my lab mates and colleagues, Brittany Lancellotti, Bianca Ross, Andy Paolucci, Jennifer Cooper, Alissa Cox, Sara Wigginton, Amber Hardy, Thomas Privott, Brett Still, Emily Patrolia, Joseph Dwyer, and Rob Hollis for lending a helping hand, guiding insight, and great friendship over the years. In addition, I would like to thank Dr. Arthur Gold, Deb Bourassa, and the rest of the Natural Resources 
Science Department for their help, and making my time at URI so rewarding and memory-filled.

The greatest appreciation of all goes to my parents Kathryn Perry and Gregory Duball, and my brother, Joseph Duball. Your constant love, positivity, and unwavering support is what keeps me going and motivates me to be the person I am today. I would also like to thank the rest of my family and friends for supporting me throughout this process, and for making Rhode Island my home away from home. 


\section{PREFACE}

This thesis was prepared in manuscript format as specified by the University of Rhode Island Graduate School guidelines. Manuscript 1 entitled "Impacts of oyster aquaculture on water quality in Rhode Island coastal lagoons" was formatted for publication in the Soil Science Society of America Journal. Manuscript 2 entitled

"Impacts of oyster aquaculture on subaqueous soils and resident benthic infauna in Rhode Island coastal lagoons" is also formatted for publication in the Soil Science Society of America Journal. 


\section{TABLE OF CONTENTS}

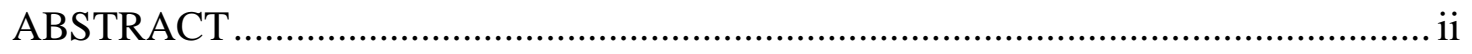

ACKNOWLEDGEMENTS …………………………....................................... v

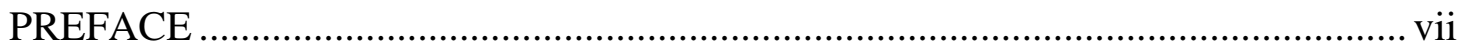

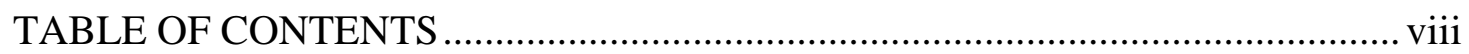

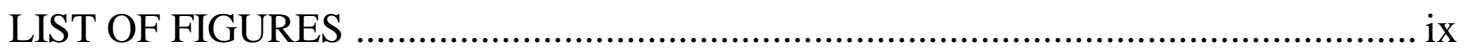

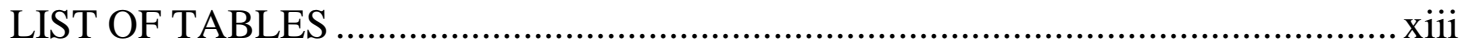

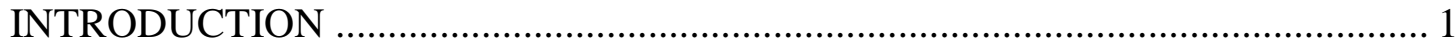

1. MANUSCRIPT I: IMPACTS OF OYSTER AQUACULTURE ON WATER QUALITY IN RHODE ISLAND COASTAL LAGOONS …………..................... 5

2. MANUSCRIPT II: IMPACTS OF OYSTER AQUACULTURE ON SUBAQUEOUS SOILS AND RESIDENT BENTHIC INFAUNA IN RHODE

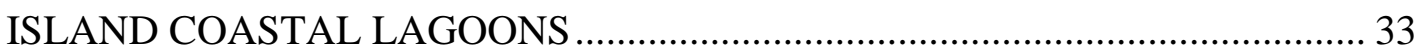

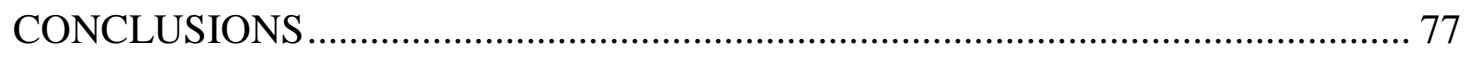

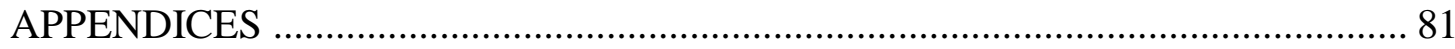

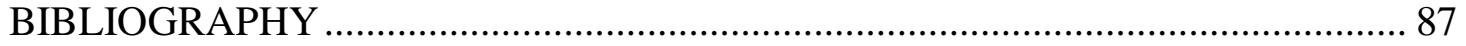




\section{LIST OF FIGURES}

FIGURE

PAGE

Figure 1.1 Location map of water quality monitoring sites in coastal lagoons of southern Rhode Island. Inset maps show aquaculture and control site locations in Winnapaug Pond (WP), Ninigret Pond (NP), and Potter Pond (PP). Monthly water samples were taken at each site from May to October of 2016.

Figure 1.2 Example of a soil map for Ninigret Pond, mapped by the efforts of the MapCoast partnership. Subaqueous soils from this research were all Nagunt sands (mixed, mesic Sulfic Psammowassents), designated by the unit (WNa0). Source: https://casoilresource.lawr.ucdavis.edu/gmap/.

Figure 1.3 Mean $(n=3)$ water temperature at aquaculture and control sites within three coastal ponds in southern Rhode Island in 2016. Error bars represent one standard deviation. There were no significant differences in temperature among aquaculture and control sites based on two-way ANOVA of water temperature across site type and month.

Figure 1.4 Mean $(n=3)$ salinity in aquaculture and control sites within three coastal ponds in southern Rhode Island in 2016. Bars represent one standard deviation. There were no significant differences in salinity among aquaculture and control sites based on two-way ANOVA of water temperature across site type and month.

Figure 1.5 Mean $(\mathrm{n}=3) \mathrm{pH}$ at aquaculture and control sites within three coastal ponds in southern Rhode Island in 2016. Bars represent one standard deviation. There were no significant differences in $\mathrm{pH}$ among aquaculture and control sites based on twoway ANOVA of water temperature across site type and month.

Figure 1.6 Mean $(n=3)$ chlorophyll a at aquaculture and control sites within three coastal ponds in southern Rhode Island in 2016. Error bars represent one standard deviation. There were significant differences in chlorophyll a among aquaculture and control sites based on two-way ANOVA of chlorophyll a across site type and month. Months with significant differences between aquaculture and control sites are indicated with an asterisk $(*)$. 
Figure 1.7 Mean $(\mathrm{n}=3)$ dissolved oxygen at aquaculture and control sites within three coastal ponds in southern Rhode Island in 2016. Bars represent one standard deviation. There were no significant differences in dissolved oxygen among aquaculture and control sites based on two-way ANOVA of water temperature across site type and month.

Figure 1.8 Mean $(n=3)$ total suspended solids in aquaculture and control sites within three coastal ponds in southern Rhode Island in 2016. Bars represent one standard deviation. There were no significant differences in total suspended solids among aquaculture and control sites based on two-way ANOVA of water temperature across site type and month.

Figure 1.9 Mean $(n=3)$ ammonium levels in aquaculture and control sites within three coastal ponds in southern Rhode Island in 2016. Bars represent one standard deviation. There were no significant differences in ammonium levels among aquaculture and control sites based on two-way ANOVA of water temperature across site type and month.

Figure 1.10 Mean $(n=3)$ nitrate levels at aquaculture and control sites within three coastal ponds in southern Rhode Island in 2016. Bars represent one standard deviation. There were no significant differences in nitrate levels among aquaculture and control sites based on two-way ANOVA of water temperature across site type and month.

Figure 1.11 Example of IRIS tube reactions from soils at control and aquaculture sites. Minimal black color indicates low sulfide presence within the soil-pore water at control sites. Greater magnitude of black color indicates higher soil pore-water sulfide levels at aquaculture sites. Note that aquaculture site tubes are totally black, compared to control sites which only have few patches black from of Fe monosulfide formation. Depth increments are provided to indicate the full range of the soil profile from 0 to 20 $\mathrm{cm}$.

Figure 2.1 Oyster aqauculture growing techniques and apparatuses. Upweller apparatus is utilized for nursing seed to juvenile sized oysters. Grow-out (on- and offbottom) techniques are utilized for juvenile to adult oysters.

Figure 2.2 Map of study sites in southern Rhode Island. Inset maps show soil sampling locations in Winnapaug Pond (WP), Ninigret Pond (NP), and Potter Pond (PP). We sampled soil and benthic cores at all aquaculture and control sites. The control site in NP was also used for the fertilization experiment. 
Figure 2.3 Mean $(n=3)$ bulk density at different soil depths as a function of years in aquaculture. Error bars represent one standard deviation from the mean. Significant differences from the control site (0 years) are indicated with an asterisk (*). Significant differences between depth increments at each age site are indicated by letters.

Figure 2.4 The relationship between oyster size $(\mathrm{cm})$ and biodepostion rate $(\mathrm{g} D W$ oyster $\left.^{-1} \mathrm{~d}^{-1}\right)$.

Figure 2.5 Mean total $\mathrm{N}$ and $\mathrm{C}$ levels in the soil as a function of time after application of biodeposits. Error bars represent one standard deviation from the mean. Soils were sampled from the upper $2 \mathrm{~cm}$ of the soil profile at $0,1,3.5$ and 7 days after biodeposits were applied to the soil surface. 66

Figure 2.6 Mean $(n=3)$ levels of total $N$ at different soil depths as a function of years in aquaculture. Error bars represent one standard deviation from the mean. Significant differences from the control site (0 years) are indicated with an asterisk (*). Significant differences between depth increments at each age site are indicated by letters.

Figure 2.7 Mean $(n=3)$ levels of total $\mathrm{C}$ at different soil depths as a function of years in aquaculture. Error bars represent one standard deviation from the mean. Significant differences from the control site (0 years) are indicated with an asterisk (*). Significant differences between depth increments at each age site are indicated by letters.

Figure 2.8 Mean $(\mathrm{n}=3) \Delta \mathrm{pH}$ at different soil depths as a function of years in aquaculture. Error bars represent one standard deviation from the mean. Significant differences from the control site (0 years) are indicated with an asterisk (*). Greater changes in $\mathrm{pH}$ were equated to higher soil sulfide levels. This assumed equal buffering capacity and acid neutralization in all the soils.

Figure 2.9 Relative distribution of functional feeding group for total mean abundance of infauna in aquaculture and control sites.

Figure 2.10 Mean $(n=5)$ abundance of infauna and functional feeding groups as a function of years in aquaculture. Each mean represents average number of infauna from a $1570 \mathrm{~cm}^{3}$ soil core. Error bars represent one standard deviation from the mean. Significant differences from the control site (0 years) are indicated with an asterisk (*) 
Figure 2.11 Mean $(n=5)$ diversity of infaunal functional feeding groups as a function of years in aquaculture. Each mean represents calculated Shannon-Wiener Diversity index values among infauna collected in a $1570 \mathrm{~cm}^{3}$ soil core. Error bars represent one standard deviation from the mean.

Figure 2.12 Calculated mean $(n=3) \mathrm{N}$ and $\mathrm{C}$ pools at different depth ranges. $\mathrm{N}$ and $\mathrm{C}$ pools represent the function of bulk density and total $\mathrm{N}$ or $\mathrm{C}$ concentrations, per age site. Error bars represent one standard deviation from the mean. The green bar represents the mean total $\mathrm{N}$ or $\mathrm{C}$ pool for each site. 


\section{LIST OF TABLES}

TABLE

PAGE

Table 1.1 Coastal lagoon properties and characteristics (Pfieffer Herbert, 2007;

Beutel, 2015). 32

Table 2.1 Comparison of previously published oyster biodeposition rates with those in our study. 74

Table 2.2 Functional feeding group identification key and ecological descriptions... 75

Table 2.3 Top five species comparison for control and aquaculture sites. 76 


\section{INTRODUCTION}

The coastal lagoons of Rhode Island are shallow, productive estuaries which serve as critical areas for economic, recreational, and ecosystem function. Expansion of development and use of the lagoons has led to increased contamination from stormwater runoff, septic system wastewater, and agricultural runoff (RI SAMP, 1999). As development of urban and coastal areas have expanded since pre-industrial times, nitrogen inputs have consequentially doubled, causing excess eutrophication to coastal ecosystems (Nixon, 1997). Eutrophication is the process by which the rate of supply of organic matter is increased within an ecosystem, and in coastal systems, this process is particularly stimulated by nitrogen inputs (Nixon, 1993). As nitrogen loading increases in enclosed estuaries like coastal lagoons, greater growth of algae occurs and the dissolved oxygen necessary for aquatic life can be depleted (RI SAMP, 1999).

One solution to limit the effects of eutrophication in coastal waters is to increase filter-feeding bivalve populations by expanding aquaculture efforts (Ulanowicz and Tuttle, 1992; Rice, 2000). Oysters, in particular, help to control phytoplankton growth by removing them from the water column via filter feeding (Cloern, 1982; Officer et al., 1982). When grazed insufficiently phytoplankton populations can increase excessively, and when these larger populations settle and decompose in the benthic environment; this raises concerns of anoxia (or oxygendepletion) in the water column and soil (Pearson and Rosenberg, 1978). Oysters serve as a filtration tool that could improve water clarity and prevent anoxic conditions within the water and benthic environment. 
Although oyster aquaculture can have a significant role in maintaining water quality, it also has the potential to have negative environmental effects (Black, 2001; Magill et al., 2006; Rice, 2000). As oysters feed on particulate matter, they consolidate and excrete the undigested portion as feces or pseudofeces, also known as biodeposits. Biodeposition by filter-feeding bivalves is important in the transfer of organic nitrogen in phytoplankton and particulates in the water column to the underlying soil, a process known as benthic-pelagic coupling (Doering et al., 1987; Dame, 2012). Because biodeposits are naturally fast sinking, they also raise a concern for organic material accumulation to the benthos (Black, 2001; Magill et al., 2006). Under certain conditions, if too many oysters are farmed in one location, it may result in increased biodeposition that could overwhelm the capacity of substrates to maintain nitrification processes (Rice, 2000).

In Rhode Island, coastal lagoons (locally identified as coastal salt ponds) have become a focal area for the expansion of oyster aquaculture (RISMP, 2014). Currently, the majority of farms in Rhode Island's coastal lagoons are sited in shallow areas with a sufficient flow regime to provide food to the oysters, and on sandy soils, which ease site accessibility for farm workers (Hines and Brown, 2012; RISMP, 2014). As the oyster aquaculture industry continues to expand its range of cultivation in these areas, there is an increasing need to understand the environmental impacts of aquaculture on the environment. Previous research shows the promise of sustainability for oyster aquaculture, but only through the development of proper management practices and strategies for the coastal lagoons. 
I gathered information on water quality, soil properties, and benthic infauna as indicators of the environmental impact of oyster aquaculture. My thesis is divided into two parts: Manuscript 1, impacts of oyster aquaculture on water quality; Manuscript 2, impacts of oyster aquaculture on the soils and resident benthic infauna. In the first manuscript, I monitored water quality from May to October, at aquaculture and control sites within three coastal lagoons in southern Rhode Island. I measured temperature, $\mathrm{pH}$, salinity, chlorophyll $a$, dissolved oxygen, and total suspended solids across all sites, and also measured soil pore-water sulfides to examine the extended impacts of water quality on the adjacent soils. Using these data I was able to identify which water quality parameters were impacted by the presence of oyster aquaculture, and which trends were seasonally driven.

In the second manuscript, I established in situ rates and $\mathrm{N}$ and $\mathrm{C}$ concentrations of biodeposits from cultured oysters in three coastal lagoons. Although others have measured biodeposition rates, few studies have assessed the composition of $\mathrm{N}$ and $\mathrm{C}$ in the biodeposits and the subsequent effects of $\mathrm{N}$ and $\mathrm{C}$ enrichment on the soils and infauna. Thus, as a follow-up I investigated the potential for various oyster stocking densities (control - no oysters, average, high) to increase $\mathrm{N}$ and $\mathrm{C}$ concentrations in the soil, via biodeposits. Finally, I collected soil cores from aquaculture and control sites, to analyze the impacts of aquaculture on the soil and infauna at various durations of continuous aquaculture use ( $0-20$ years). Soil cores were analyzed for bulk density, particle size, total N, total C, soil sulfide levels, and to identify the resident benthic infauna present. Using these data, I was able to assess 
which components of the benthic environment were affected by biodeposition and aquaculture practices.

Together these studies provide a useful approach to analyzing the environmental impacts from oyster aquaculture on the coastal lagoons. Results from these studies will help to determine the magnitude of environmental impact from aquaculture as a function of both the number of years of continuous aquaculture use and density of oysters grown. This research will provide useful data on the effects of oysters and aquaculture practices on water quality, soils, and infauna to conservation managers, shellfish farmers, and research scientists. 


\title{
MANUSCRIPT I: IMPACTS OF OYSTER AQUACULTURE ON WATER QUALITY IN RHODE ISLAND COASTAL LAGOONS
}

\author{
In preparation for submission to Soil Science Society of America Journal \\ Chelsea E. Duball ${ }^{*}$, Mark H. Stolt ${ }^{1}$, Jose A. Amador ${ }^{1}$ \\ ${ }^{1}$ Department of Natural Resources Science, University of Rhode Island, 1 Greenhouse \\ Road, Kingston, RI 02881 \\ *Corresponding author: Chelsea Duball \\ Laboratory of Pedology and Soil-Environmental Science \\ University of Rhode Island, Coastal Institute, \\ 1 Greenhouse Rd., Kingston, RI 02881 \\ E-Mail: chelsea_duball@my.uri.edu
}




\begin{abstract}
In Rhode Island, coastal lagoons are a focal area for expansion of shellfish aquaculture, while many have water quality issues because of anthropogenic inputs. In response to these issues, several studies have proposed oyster aquaculture (Crassostrea virginica, the Eastern Oyster) as a way to restore or improve water quality in coastal systems, because of their controlling effect on primary production and nutrient cycling in the water column, via filter feeding processes. In this study, we assessed the impact of oyster aquaculture on water quality in coastal lagoons of Rhode Island by monitoring water quality in aquaculture and control sites. We monitored water quality by measuring parameters such as, $\mathrm{pH}$, temperature, salinity, dissolved oxygen, chlorophyll $a$, total suspended solids, ammonium, and nitrate between May and October in 2016, for three coastal lagoons (Ninigret, Winnapaug, Potter ponds). To examine the relationship between the water column and the benthic environment, we also analyzed soil pore water sulfide levels. Results showed no significant differences in $\mathrm{pH}$, temperature, salinity, dissolved oxygen, total suspended solids, ammonium, or nitrate between aquaculture and control sites, across all months. On the contrary, chlorophyll $a$ levels were significantly lower at aquaculture sites compared to control sites, during warmer months from June to October. Both aquaculture and control sites showed evidence of pore water sulfides, however, aquaculture sites had a greater presence of sulfides, specifically in the upper $10 \mathrm{~cm}$ of soil profile. Our results suggest, oysters have a significant impact on controlling phytoplankton levels in the water column, with minimal effects on other variables of the water column. As oysters help to increase phytoplankton control via filter-feeding,
\end{abstract}


our results also suggest the by-products from this process may increase organic loads to the soil environment, thus increasing soil pore-water sulfide levels.

\section{INTRODUCTION}

Coastal lagoons, also referred to as salt ponds, are unique ecosystems, functioning at the interface of marine and terrestrial systems. In the past decade increased use of these lagoons, and their respective watersheds (e.g. housing development, human recreation, commercial fisheries), has led to an increase in pollutant loadings that threaten water quality, the quality of life for local residents, and potentially the economy of the region (Edwards 1984; Anderson and Edwards, 1986;

Olsen and Lee, 1991). Sources of contamination include wastewater from septic systems, stormwater runoff, and runoff from agricultural fertilizers (RI SAMP, 1999). These anthropogenic impacts have resulted in nutrient loads capable of altering ecosystem conditions. Nixon and Buckley (2007) concluded that nitrogen (N) loads to all of the lagoons were already at or beyond the recommended limit of $30 \mathrm{~kg} \mathrm{~N} \mathrm{ha}^{-1} \mathrm{y}^{-}$ ${ }^{1}$, above which eelgrass die-off takes place (Hauxwell et al., 2003). As we face ecosystem-altering $\mathrm{N}$ loads in these high-use areas, we need to understand how excess $\mathrm{N}$ may affect water quality, and how we can manage these effects.

Increased levels of $\mathrm{N}$ in estuarine systems lead to excess primary productivity, known as eutrophication. Eventually, the excess phytoplankton and algae dies, and the subsequent microbial decomposition results in oxygen depletion (hypoxia), or complete oxygen removal (anoxia) (Nixon, 1993). Hypoxia causes stress in many 
animals, reducing growth and reproduction, and anoxia may kill those that cannot leave the area (Nixon 1993; Nixon and Buckley, 2007). Additionally, increased algal production may cover submerged aquatic vegetation and decrease light availability (Nixon and Buckley, 2007). The combined effects of eutrophication pose a cascading threat to the water quality and associated ecosystem services (e.g. fish and shellfish production, recreation, nutrient cycling) of coastal lagoons.

Oyster aquaculture may be a way to restore or improve water quality in coastal systems (Ulanowicz and Tuttle, 1992; Rice et al., 2000). An oyster can filter between 15 and 55 liters of seawater per day, consuming phytoplankton and excess nutrients in the process (Powell et al., 1992), and helping to control phytoplankton growth (Cloern, 1982; Officer et al., 1982). Through this action, both phytoplankton and suspended sediment that would otherwise reduce water clarity are drawn from the water column to the benthos (Ermgassen et al., 2013). As such, oysters serve as a critical link between primary production, sedimentation, and nutrient cycling in the water column and the benthos (Bertness, 2007; Coen and Grizzle, 2007; Higgins et al., 2011; 2013; Dame, 2012). These same filter-feeding processes also produce biodeposits (feces and pseudofeces) which enhance sedimentation of organic matter, and at large enough quantities, can potentially over fertilize the benthos and reduce the dissolved oxygen content of the soil (Prins et al. 1998; Hoellein et al., 2014). Although the complex interactions between filter-feeders and their environment are not yet fully understood, native and introduced bivalves - including those in aquaculture farms - have been documented to have significant positive impacts on 
water quality (French McCay et al., 2003; NRC, 2004; Cerco and Noel, 2007; Grant et al., 2007; Dame, 2012).

There has been a sustained effort to monitor the water quality of Rhode Island's watersheds and coastal areas across a suite of water quality parameters (e.g. chlorophyll a, $\mathrm{pH}$, temperature, nutrients, dissolved oxygen, total suspended solids, and turbidity). These data are available for public use through a collaboration of the Rhode Island Salt Ponds Coalition (RISPC) and The University of Rhode Island's Watershed Watch Program (www.saltpondscoalition.org). Although this database provides monthly water quality reports about the coastal lagoons, little to no data are currently available for managed areas, such as shellfish aquaculture farms. These data would be useful to aquaculture farmers, land-use and coastal managers, and the public, to identify suitable waters for aquaculture practices, and to monitor the capacities of oyster aquaculture to enhance water quality and other ecosystem services.

We assessed the impact of oyster aquaculture on water quality in Rhode Island's coastal lagoons by monitoring parameters in areas currently used for oyster aquaculture, compared to similar areas not previously used for aquaculture. We monitored water column $\mathrm{pH}$, temperature, salinity, dissolved oxygen (DO), ammonium, nitrate, chlorophyll a ( $\operatorname{chl} a$ ), and total suspended solids (TSS) between May and October in 2016, for three coastal lagoons in southern Rhode Island. To examine the relationship between the water column and the affected inundated soils, we also analyzed the presence of soil-pore water sulfides. We hypothesized that aquaculture sites would have reduced chl $a$ levels and lower TSS, due to increased filter-feeding activity, resulting in improvement in levels of DO, ammonia, and nitrate. 
Additionally, as the oysters improve water quality via filter feeding, the excess of what is not digested is distributed to the benthic environment in the form of biodeposits. As a result of increased biodeposition to the soil from filter feeding, we also expected to see higher pore-water sulfide levels at aquaculture sites compared to control sites.

\section{METHODOLOGY}

\section{$\underline{\text { Study Sites }}$}

We measured water quality at oyster aquaculture and control sites in three coastal lagoons on the south coast of Rhode Island: Ninigret, Winnapaug, and Potter Ponds (Figure 1.1). These lagoons were chosen because they have preexisting aquaculture leases actively farmed for oysters. All of the aquaculture leases are located on shallow washover fans that typically have sandy Nagunt soil types (mixed, mesic Sulfic Psammowassents) (Figure 1.2). These shallow lagoons are permanently breached by narrow inlets that exchange seawater from Block Island Sound, and have an average water depth of $<2 \mathrm{~m}$ (Boothroyd, Friedrich, and McGinn, 1985). Flushing times average $<5$ days (Table 1.1) and nitrogen inputs average $30 \mathrm{~kg} \mathrm{~N} \mathrm{ha}^{-1} \mathrm{yr}^{-1}$ (Pfeiffer-Herbert, 2007). High N loads and low flushing rates make these ponds ideal systems for evaluating impacts of oyster aquaculture on water quality.

Aquaculture monitoring sites were established directly between oyster racks of actively farmed aquaculture areas, while control sites were established in areas not previously utilized for shellfish aquaculture. Both aquaculture and control sites were located on soils mapped as Nagunt sands, with water depths $<1.5 \mathrm{~m}$. Control sites 
were chosen in areas that had minimal effects from recreational activity, and were at least $300 \mathrm{~m}$ from any oyster aquaculture farms, while still on the washover fan (Figure $1.1)$.

\section{Water Quality Monitoring}

Water quality was monitored once a month at aquaculture and control sites within each of the three ponds, from May to October, 2016. We measured temperature, salinity, $\mathrm{pH}, \mathrm{chl} a, \mathrm{DO}, \mathrm{TSS}$, ammonium, and nitrate within the water column. Temperature, salinity, DO, $\mathrm{pH}$, were measured in the afternoon - when DO and temperature were expected to peak - and at mid-tide. Measurements of temperature, salinity, $\mathrm{pH}$, and DO were made using a YSI-556 digital probe (YSI Environmental, Yellow Springs, $\mathrm{OH})$ that was placed $\sim 0.5 \mathrm{~m}$ below the water surface, roughly level with the top of aquaculture racks. Samples for chl a, ammonium, and nitrate analysis, were collected at the same depth in two, 150-mL tinted bottles samples, per site, and a portion of the sample used for ammonium and nitrate analyses. Two, 200-mL samples were collected from the same depth for TSS analysis. All water samples were kept on ice in the field, stored out of the sunlight, and refrigerated in the lab.

Immediately upon returning to the lab, chl $a$ samples were prepared for analysis by adding four drops of $\mathrm{MgCO}_{3}$ solution to $50 \mathrm{~mL}$ of sample and filtering the solution through a Gilman Sciences glass-fiber filter (25-mm diameter). The filters were wrapped in foil and stored at $-15^{\circ} \mathrm{C}$ until processing. Chlorophyll $a$ was extracted from the filter using acetone $(20 \mathrm{~mL})$ and the concentration of chl $a$ was 
determined fluorometrically (Clesceri et al., 1998). The filtered water from chl. $a$ filter preparation, was stored in the freezer and analyzed for ammonium and nitrate using an Astoria Pacific Model 303A Segmented Continuous Flow Autoanalyzer (Astoria-Pacific Inc.). Samples for TSS analysis were processed within $48 \mathrm{~h}$ of collection. Two replicate, 200-mL samples were vacuum-filtered through a Millipore glass fiber filter (47-mm dia.) for each monitoring site, dried at $105^{\circ} \mathrm{C}$, weighed, and TSS was calculated according to Clesceri et al. (1998).

\section{$\underline{\text { Soil Pore-water Sulfides }}$}

To assess the pore water sulfide levels, we used IRIS (Indicator of Reduction In Soils) tubes. The tubes were constructed from PVC tubing and painted with iron oxide paint following the protocol of Rabenhorst (2008). This method has been used successfully to measure $\mathrm{H}_{2} \mathrm{~S}$ levels in marsh soil pore water, whereby sulfides react with the Fe-paint on the tubes to form insoluble Fe-monosulfides and pyrite, producing a black color (Rabenhorst et al., 2010). The extent of color change on each tube was used to estimate sulfide levels within the upper $20 \mathrm{~cm}$ of the saturated soil. The tubes were inserted into the soil at both aquaculture and control sites for 2 days in early August 2016, in sets of three, placed roughly $20 \mathrm{~m}$ apart to account for soil variability within each established aquaculture and control site.

\section{$\underline{\text { Statistical analysis }}$}

We used SigmaPlot v.11.2 software for all statistical analyses (Systat Software Inc., San Jose, CA). All data that failed tests of normality and equal variance were 
Log-transformed. We treated each pond as a replicate for all statistical tests. Each water quality parameter was compared across site type (aquaculture vs. control) and month using a two-way analysis of variance (ANOVA), with a significance level of $\alpha$ $=0.05$.

\section{RESULTS}

\section{Water Quality Characteristics}

We examined temperature, salinity, $\mathrm{pH}, \operatorname{chl} a, \mathrm{DO}, \mathrm{TSS}$, ammonia, and nitrate as indicators of water quality at oyster aquaculture sites and control sites in three coastal lagoons in southern Rhode Island. Water quality parameters were measured level with aquaculture cage height (approximately $0.5 \mathrm{~m}$ deep from the water column surface) and monitored for six months (May-October 2016).

Temperature, salinity, and $\mathrm{pH}$ were not expected to change as a result of aquaculture activity; they were monitored to assess the overall suitability of the water column to support oyster aquaculture. Water temperature varied seasonally, with a range of $15.9-28.0^{\circ} \mathrm{C}$ across all sites (Figure 1.3). Temperature was not significantly different $(\mathrm{P}=0.451)$ between aquaculture and control sites, across all months. Highest water temperatures were observed between June and September (20.3 - $28.0^{\circ} \mathrm{C}$ ). Salinity ranged between 25.9 and 29.4 ppt (Figure 1.4), and were not significantly different $(\mathrm{P}=0.513)$ among aquaculture and control sites across all months. $\mathrm{pH}$ also varied seasonally with a range of 6.6-8.3 (Figure 1.5), and was not 
significantly different $(\mathrm{P}=0.547)$ among aquaculture and control sites, across all months.

Chl $a$ levels ranged from 2.0- $23.7 \mu \mathrm{g} \mathrm{L}^{-1}$ (Figure 1.6) and were statistically different $(\mathrm{P}=0.029)$ among aquaculture and control sites in August. Aquaculture sites had lower chl $a$ levels compared to control sites from June to October, and higher levels in May.

DO levels ranged between 7.7 and $14.4 \mathrm{mg} \mathrm{L}^{-1}$ (Figure 1.7) across all sites. Differences in DO were not statistically significant $(\mathrm{P}=0.566)$ among aquaculture and control sites, across all months. Nevertheless, higher DO was observed at aquaculture sites in all months except for August and September.

TSS measurements ranged from 23.7 to $53.5 \mathrm{mg} \mathrm{L}^{-1}$ across all sites (Figure 1.8). The difference in mean TSS was not statistically significant $(P=0.974)$ among aquaculture and control sites, across all months.

Ammonium levels ranged from 25.0 to $96.7 \mu \mathrm{g} \mathrm{L}^{-1}$ across all sites and months (Figure 1.9). There was no significant difference $(\mathrm{P}=0.655)$ in ammonium levels across aquaculture and control sites, across all months. Nitrate levels were typically measured below the detectable amount $\left(15 \mu \mathrm{g} \mathrm{L}^{-1}\right)$, with the exception of a limited number of samples taken from aquaculture and control sites in May, June, and October (Figure 1.10). There was no significant difference $(\mathrm{P}=0.704)$ in nitrate levels among aquaculture and control sites, across all months. 


\section{$\underline{\text { Soil Pore-water Sulfides }}$}

We used IRIS tubes to examine the effects of oyster filter-feeding byproducts on the benthic environment, specifically the soil-pore-water sulfide levels. We used the extent of color change on each tube (Fe paint reduced by pore-water sulfides, results in insoluble black FeS color) to estimate pore-water sulfide levels within the upper $20 \mathrm{~cm}$ of the soil. IRIS tubes across all sites showed evidence of the presence of sulfides within the upper $20 \mathrm{~cm}$ of soil (Figure 1.11). The magnitude of black color change was greatest on IRIS tubes from aquaculture sites, with the highest sulfides concentration evident in the upper $10 \mathrm{~cm}$.

\section{DISCUSSION}

\section{$\underline{\text { Water Quality Characteristics }}$}

Water quality is an important factor for the survival and growth of oysters, and is greatly impacted by the oysters themselves. All measurements of temperature, salinity, and $\mathrm{pH}$ were within the standard ranges reported for the coastal lagoons of Rhode Island (Pfieffer-Herbert, 2007; www.saltpondscoalition.org). Although oyster aquaculture did not have a significant impact on temperature, salinity, or $\mathrm{pH}$ in this study, these variables all contribute to the health of oysters in the lagoons. Temperatures observed in this study were within the range $\left(-1.7-36.0^{\circ} \mathrm{C}\right)$ suitable for growth and survival of juvenile to adult oysters (RISMP, 2014). However, temperatures were only within the optimal range $\left(20.0-30.0^{\circ} \mathrm{C}\right)$ for juvenile to adult oysters from June to September. Salinity values were also within the optimal range 
for juvenile to adult oysters (14-28 ppt), as well as pH (6.75-8.75) (RISMP, 2014), across all months. Our data show that ambient conditions of the lagoons were generally within the optimal range for oyster aquaculture (with the exception of temperature in May and October) and were not significantly between aquaculture and control sites, across all months.

Chl $a$ concentrations provide an estimate of the levels of phytoplankton in the water column and have been identified as an important parameter related to oyster growth, as it represents a food source for the oysters (Grizzle and Lutz, 1989; Newell and Langdon, 1996; Rice, 1992; Rice and Pechenik, 1992). Our results show chl $a$ levels at aquaculture and control sites were higher than the most recent chl $a$ data available for the lagoons from 2014 (www.saltpondscoalition.org), and were within both oligotrophic $(<2.6 \mu \mathrm{g} / \mathrm{L})$ and eutrophic $(7.3-35 \mu \mathrm{g} / \mathrm{L})$ ranges, depending on the month (RISMP, 2014). Chl $a$ levels ranged from 2.0 to $23.7 \mu \mathrm{g} \mathrm{L}^{-1}$ across all sites, and were significantly lower at aquaculture sites compared to control sites in August when water temperatures were at peak level (Figure 1.6). However, aquaculture sites had lower chl $a$ levels compared to control sites for five of the six months chl $a$ was measured. We expected to see lower chl $a$ concentrations at aquaculture sites because oysters control the size of phytoplankton communities via filtration, which is optimal during warmer months $\left(20-30{ }^{\circ} \mathrm{C}\right)$ (RISMP, 2014). All sites were within the range of suitable temperatures for oyster growth in all months, however, the optimal-function temperature range was only reached between June and September, while lower than optimal temperatures were observed in May and October (Figure 1.3). The seasonal hibernation patterns of oysters, help to explain chl $a$ (filter-feeding) trends observed in 
different months. In May oysters emerge out of hibernation, whereby little to no food was consumed during colder temperatures; versus the latter parts of summer and fall, oysters increase glycogen storage via filter-feeding processes (Mitchell, 1917). This is likely why we see chl $a$ levels decrease at aquaculture sites in October and not May, since the oysters were preparing for hibernation in October by consuming larger amounts of phytoplankton to increase glycogen storage. Our data suggest that oysters have a positive controlling effect on phytoplankton within the water column, depending on the month and water temperatures.

Because chl $a$ levels are reduced by oyster filtration, we also expected to see an increase in DO levels at aquaculture sites, since oxygen in the water column is consumed during decomposition of phytoplankton (Howarth et al., 2011). Although our DO values were higher than RISPC (2014) data, a similar study conducted by Still et al. (2016) reported DO levels associated with shallow aquaculture areas within Ninigret Pond, RI, ranging from 4.7 to $12.1 \mathrm{mg} \mathrm{L}^{-1}$. In our study, DO ranged from 7.7 to $14.4 \mathrm{mg} \mathrm{L}^{-1}$ across all sites and months (Figure 1.7). Although DO was higher at aquaculture sites for four out of the six months we monitored water quality, these differences were not significant between aquaculture and control sites. While cultured-oysters aid improved water clarity via phytoplankton control, they are noted to have less of a controlling effect on DO because they typically filter the same parcel of water over and over (Blankenship, 2004). Because of high levels of DO across all sites, it is likely the effects of oyster filtration on DO levels could have been masked by other processes which improve DO levels. Higher DO levels at all sites may be explained by better mixing in shallow environments. In addition, aquaculture sites 
could have higher levels of DO due to increased mixing from routine aquaculture management practices (i.e. movement of farmers, boats, and aquaculture gear).

We also expected oyster filtration to lower TSS at aquaculture sites compared to control sites. Still et al. (2016) reported TSS values for aquaculture sites in Ninigret Pond, with a median concentration of $21.2 \mathrm{mg} \mathrm{TSS} \mathrm{L}^{-1}$, which were lower than our TSS levels, which ranged from 23.7 to $53.5 \mathrm{mg} \mathrm{L}^{-1}$ across all sites. Levels remained within the optimal range for oysters, which can tolerate up to $750 \mathrm{mg} \mathrm{TSS} \mathrm{L}^{-1}$ (RISMP, 2014). Additionally, TSS values were below $100 \mathrm{mg} \mathrm{L}^{-1}$, which is the threshold at which oyster filtration rates are reduced to 50 and $87 \%$ capacity (Loosanoff and Tommers, 1948). TSS were not significantly different across aquaculture and control sites, for all months (Figure 1.8). Higher TSS levels are common for shallow environments due to increased mixing via wind-driven circulation (Still et al., 2016), and these effects were likely enhanced in our study by the soil disturbances and resuspension caused by aquaculture practices.

We expected ammonia and nitrate levels to be lower in aquaculture sites as a result of higher filtration and consumption of phytoplankton. Within the six-month monitoring period, only $16 \%$ of samples from control sites, and $0.6 \%$ of samples from aquaculture sites had a dissolved inorganic $\mathrm{N}$ (sum of ammonium and nitrate) level that was above the $<96 \mu \mathrm{g} \mathrm{L}{ }^{-1}$ threshold indicating "poor" aquatic health (Torello and Callender, 2013). However, there was no significant difference in ammonia or nitrate levels across aquaculture and control sites. Our results show aquaculture has limited effects on $\mathrm{N}$ reduction within the water column compared to control sites. 


\section{$\underline{\text { Soil Pore-water Sulfides }}$}

We expected to see increased levels of pore-water sulfides at aquaculture sites, as a result of enhanced organic $\mathrm{C}$ inputs to the soil via oyster biodeposition. Black color changes, indicating the presence of pore-water sulfides, were observed in the upper $20 \mathrm{~cm}$ at all sites (Figure 1.11). Furthermore, our results suggest there were higher pore-water sulfide levels at aquaculture sites compared to control sites, due to the presence of greater black color changes, specifically observed in the upper $10 \mathrm{~cm}$ of the soil profile. Higher levels of pore-water sulfides are an indication of reducing and anoxic conditions in the soils at aquaculture sites. Impacts from continued organic loading generated from deposition and decay of organic material has been shown to cause a decrease in redox potential at depths deeper than $4 \mathrm{~cm}$ within the soil profile (Pearson and Stanley, 1979). Thus, our results indicate the biodeposits resulting from filter feeding processes, can alter the ecology and properties of the soils under aquaculture by increasing organic loads.

\section{CONCLUSIONS}

Our data show that oyster aquaculture has some significant positive effects on water quality, and can alter the biogeochemistry of the benthic environment. Although we measured no significant differences in DO, TSS, ammonia, or nitrate levels across aquaculture and control sites, however there were significantly lower levels of chl $a$ in aquaculture sites compared to control sites. These results suggest oysters promote phytoplankton control within the water column, helping to reduce 
effects of eutrophication and improve water clarity. In contrast, pore-water sulfide data indicate that the soils are potentially affected by the biodeposits produced from filter-feeding processes, resulting in increased pore-water sulfides levels within the upper $10 \mathrm{~cm}$ at aquaculture sites. Higher levels of pore water sulfides indicate reducing and anoxic conditions, which can be detrimental to the benthos. Together our results show that oysters can provide ecosystem services such as improving water clarity, while the impacts of biodeposition to the soil should be investigated further. Results from this study are useful to future water quality monitoring efforts and associated land use decisions for shallow lagoon areas, especially oyster aquaculture areas. 


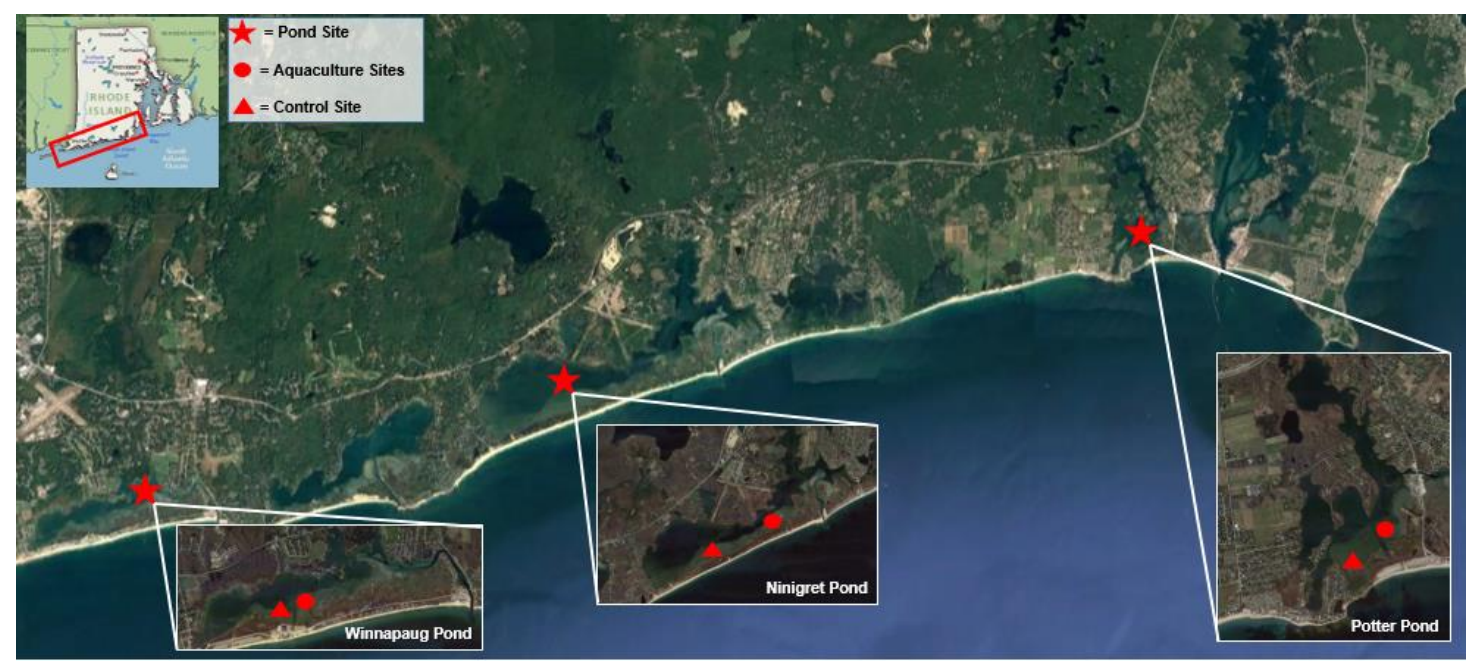

Figure 1.1 Location map of water quality monitoring sites in coastal lagoons of southern Rhode Island. Inset maps show aquaculture and control site locations in Winnapaug Pond (WP), Ninigret Pond (NP), and Potter Pond (PP). Monthly water samples were taken at each site from May to October of 2016. 


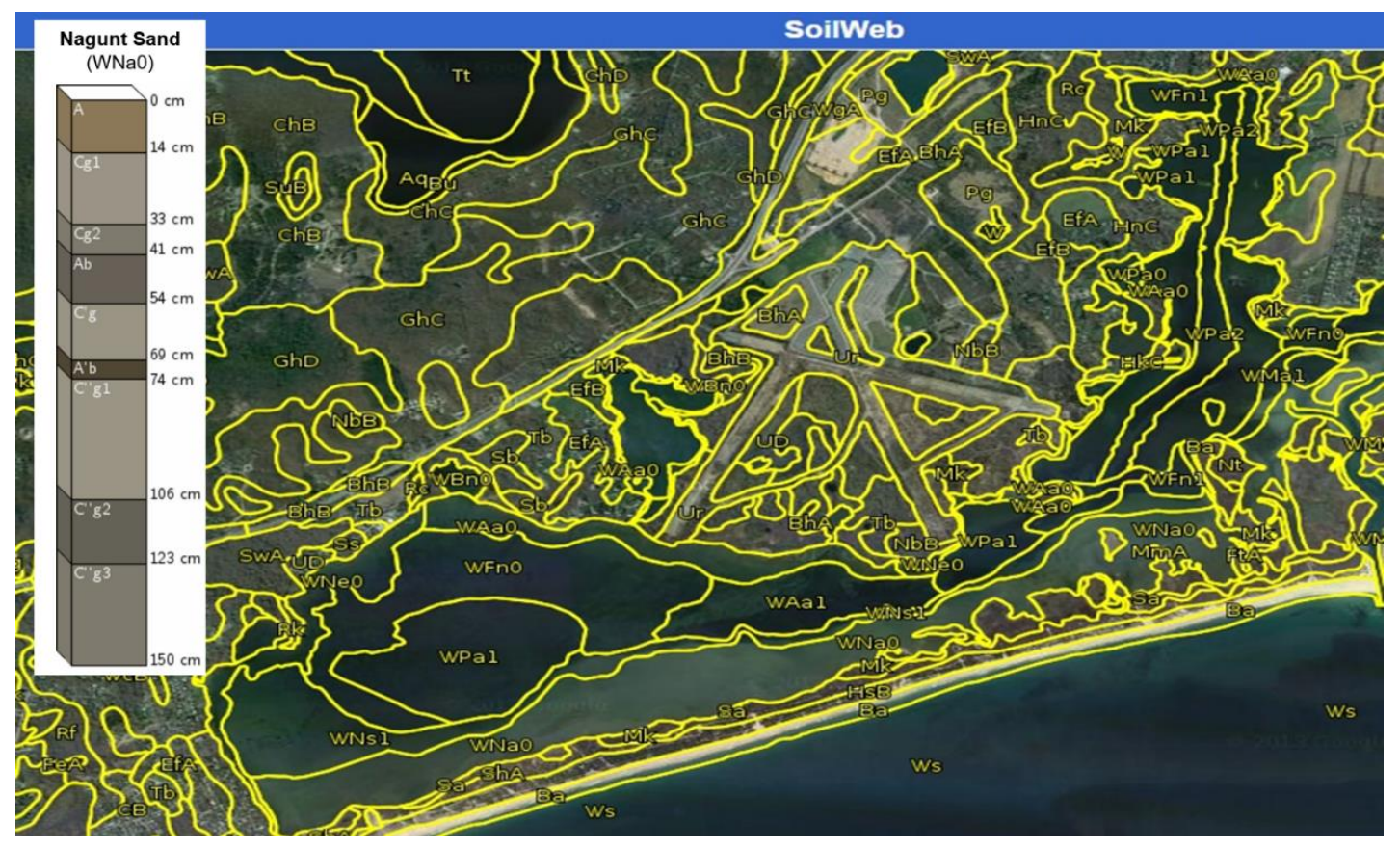

Figure 1.2 Example of a soil map for Ninigret Pond, mapped by the efforts of the MapCoast partnership. Subaqueous soils from this research were all Nagunt sands (mixed, mesic Sulfic Psammowassents), designated by the unit (WNa0). Source: https://casoilresource.lawr.ucdavis.edu/gmap/. 


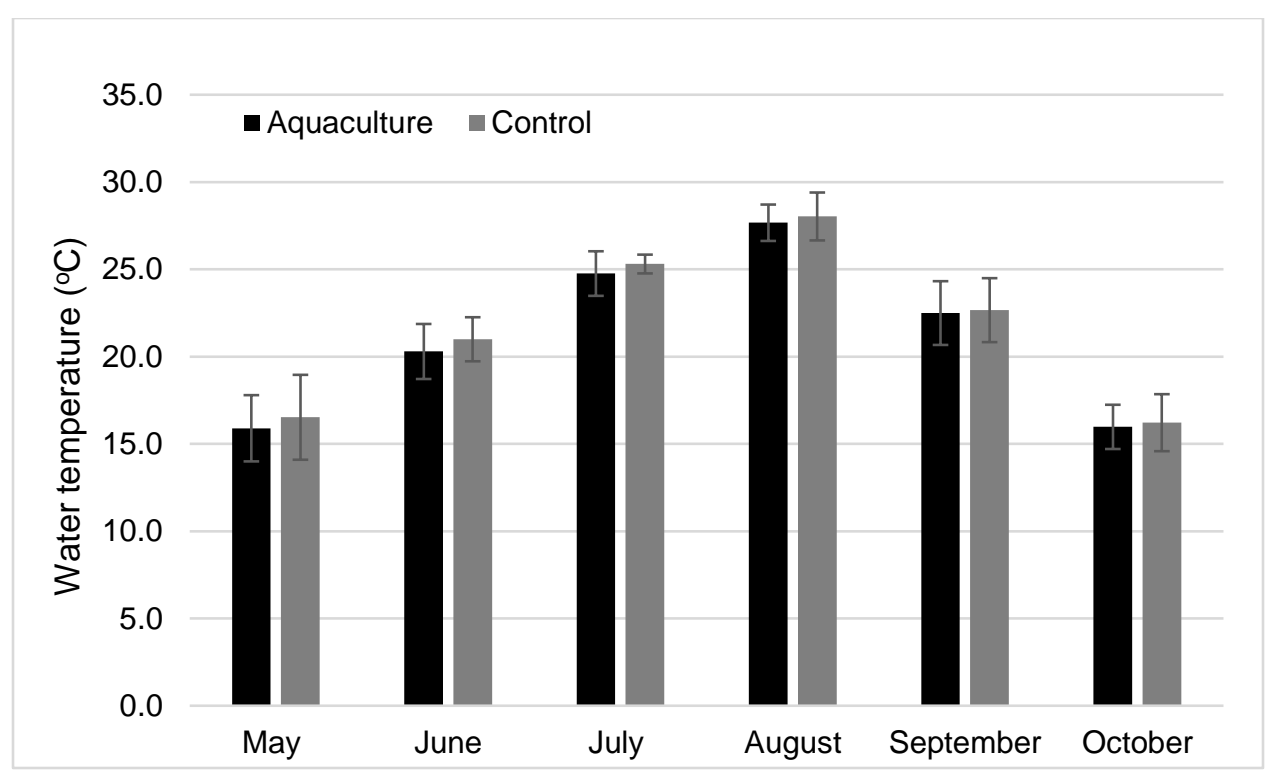

Figure 1.3 Mean ( $\mathrm{n}=3$ ) water temperature at aquaculture and control sites within three coastal ponds in southern Rhode Island in 2016. Error bars represent one standard deviation. There were no significant differences in temperature among aquaculture and control sites based on two-way ANOVA of water temperature across site type and month. 


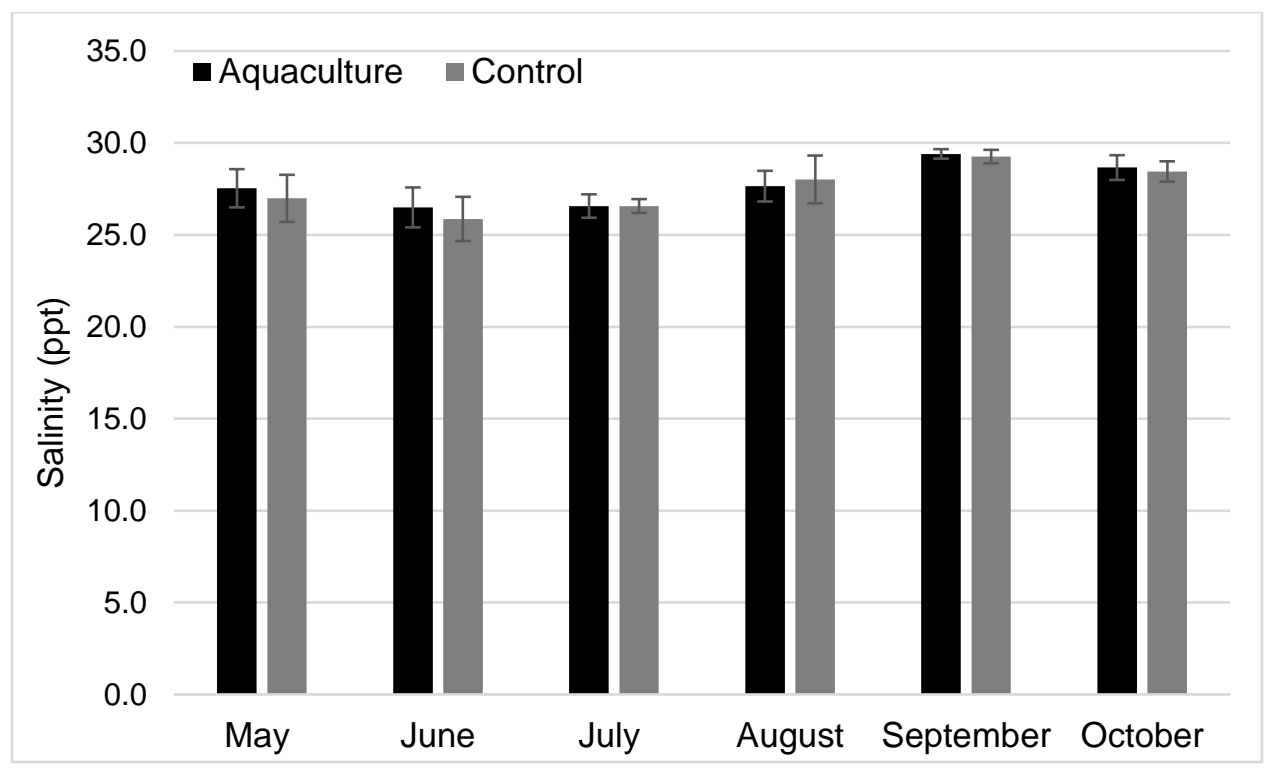

Figure 1.4 Mean $(n=3)$ salinity in aquaculture and control sites within three coastal ponds in southern Rhode Island in 2016. Bars represent one standard deviation.

There were no significant differences in salinity among aquaculture and control sites based on two-way ANOVA of water temperature across site type and month. 


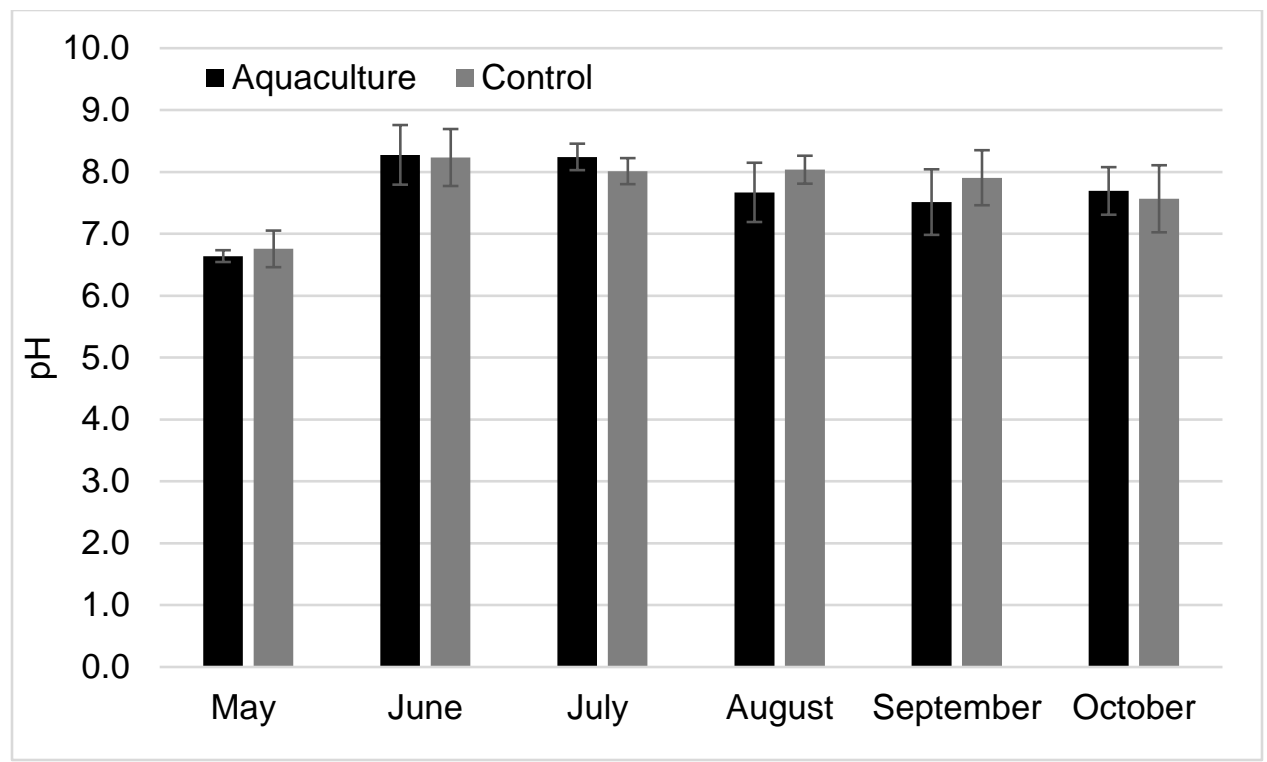

Figure 1.5 Mean $(\mathrm{n}=3) \mathrm{pH}$ at aquaculture and control sites within three coastal ponds in southern Rhode Island in 2016. Bars represent one standard deviation. There were no significant differences in $\mathrm{pH}$ among aquaculture and control sites based on twoway ANOVA of water temperature across site type and month. 


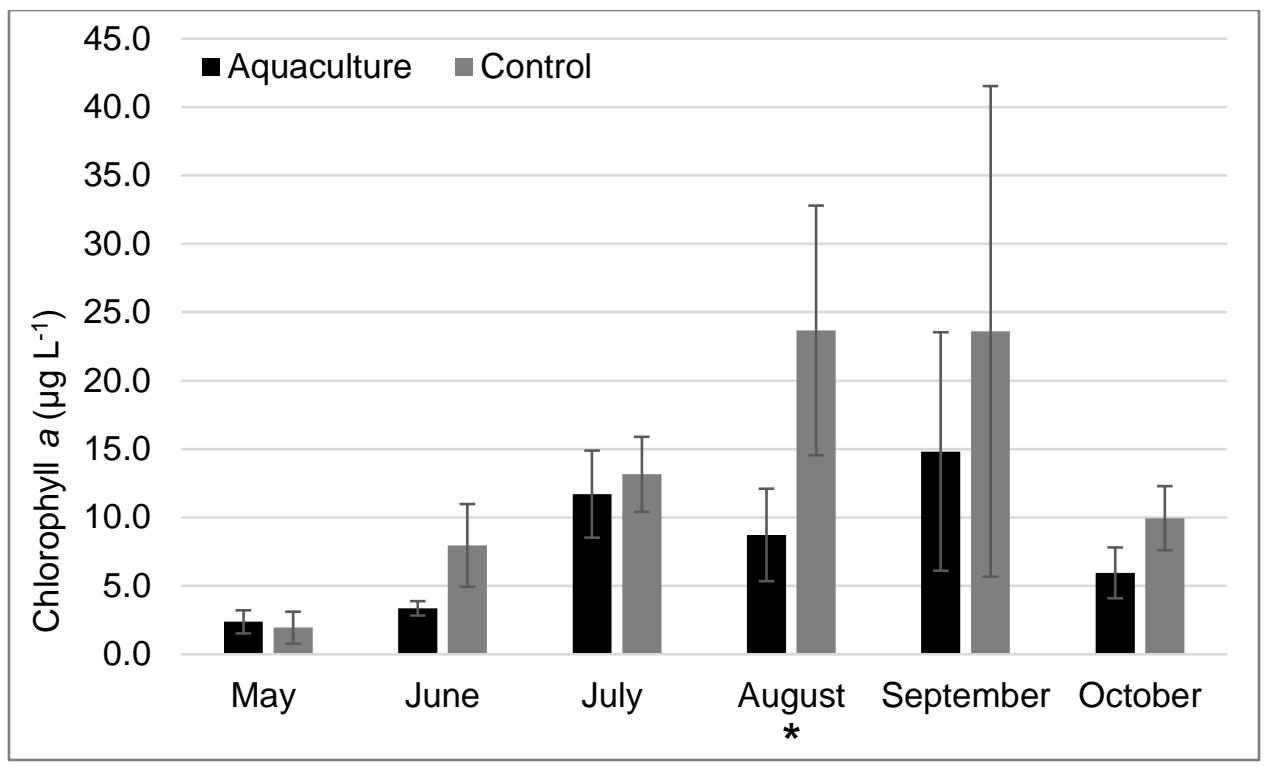

Figure 1.6 Mean $(n=3)$ chlorophyll a at aquaculture and control sites within three coastal ponds in southern Rhode Island in 2016. Error bars represent one standard deviation. There were significant differences in chlorophyll a among aquaculture and control sites based on two-way ANOVA of chlorophyll a across site type and month. Months with significant differences between aquaculture and control sites are indicated with an asterisk (*). 


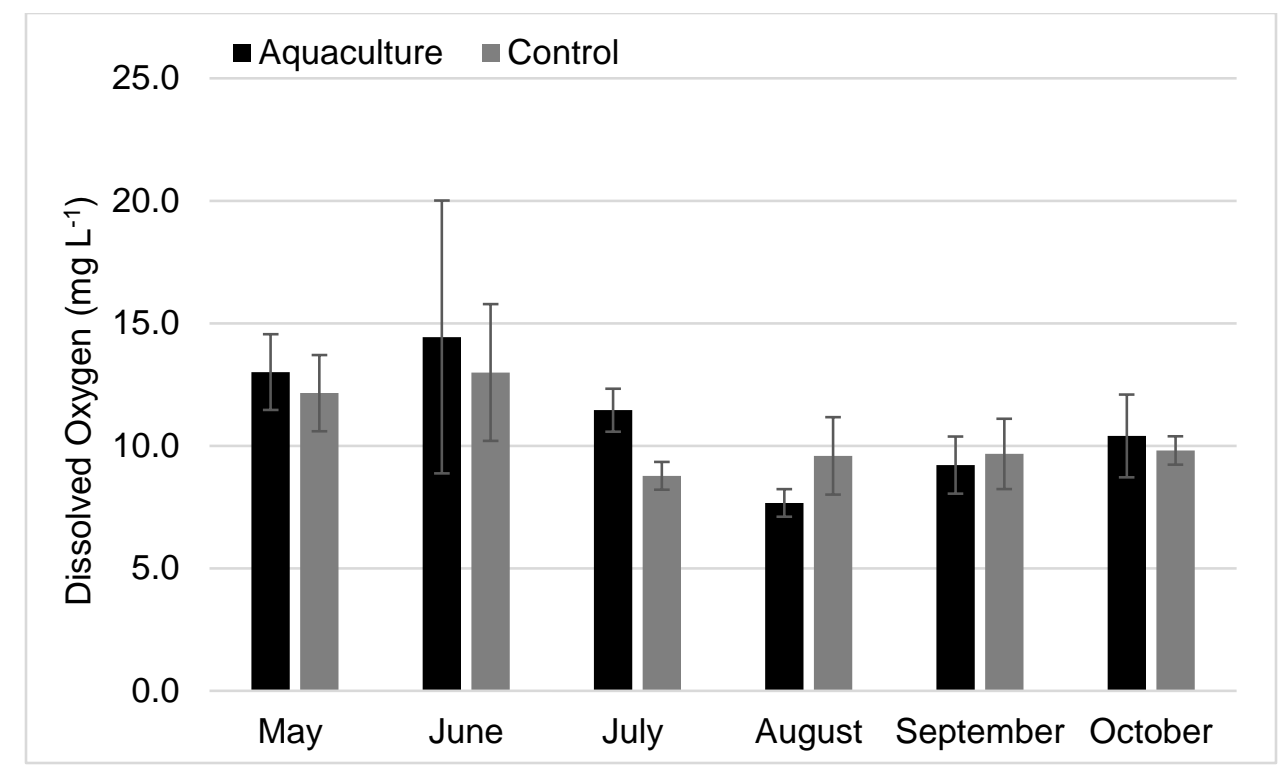

Figure 1.7 Mean $(\mathrm{n}=3)$ dissolved oxygen at aquaculture and control sites within three coastal ponds in southern Rhode Island in 2016. Bars represent one standard deviation. There were no significant differences in dissolved oxygen among aquaculture and control sites based on two-way ANOVA of water temperature across site type and month. 


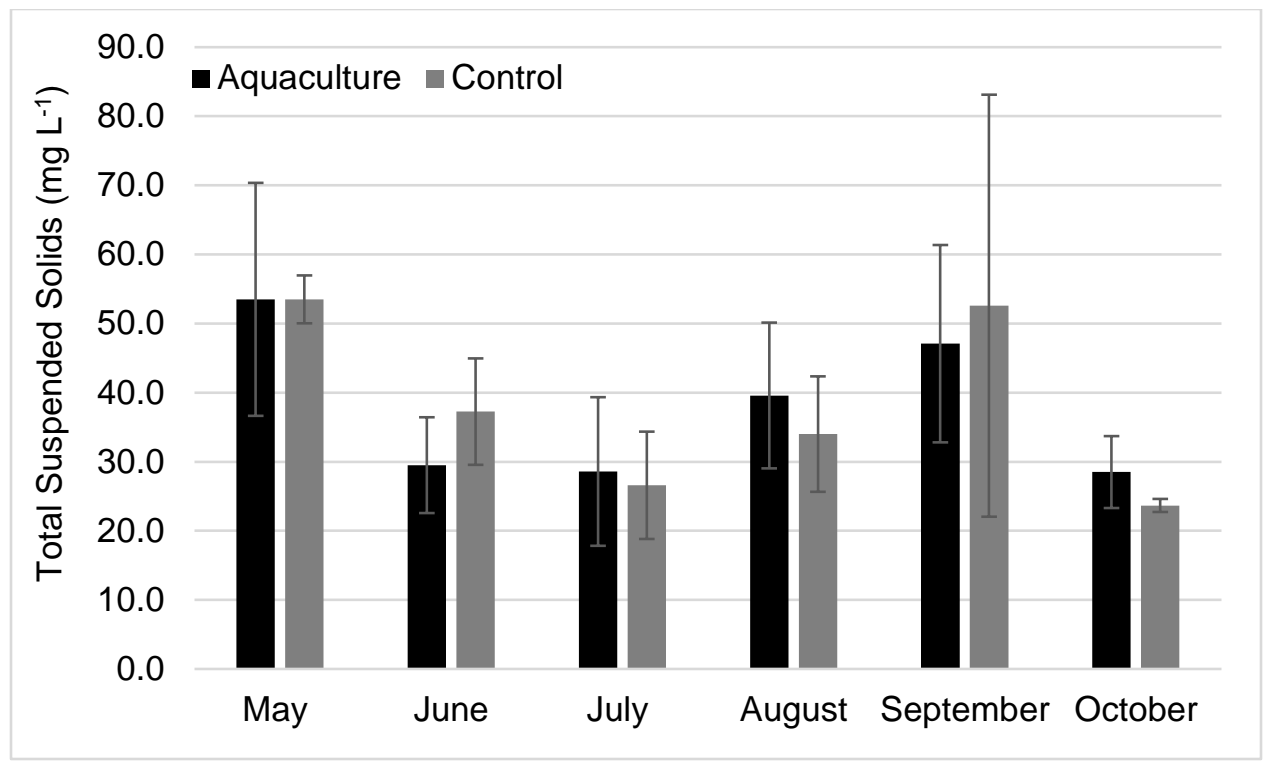

Figure 1.8 Mean $(n=3)$ total suspended solids in aquaculture and control sites within three coastal ponds in southern Rhode Island in 2016. Bars represent one standard deviation. There were no significant differences in total suspended solids among aquaculture and control sites based on two-way ANOVA of water temperature across site type and month. 


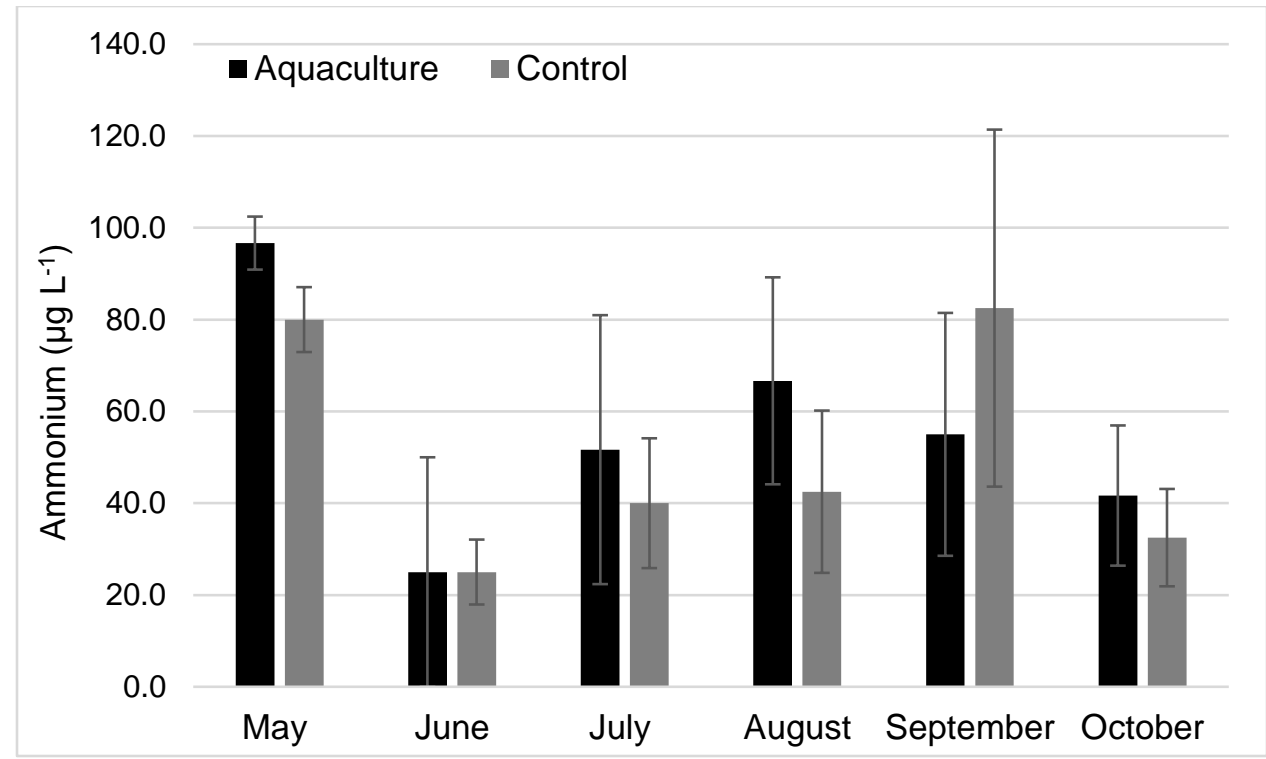

Figure 1.9 Mean $(\mathrm{n}=3)$ ammonium levels in aquaculture and control sites within three coastal ponds in southern Rhode Island in 2016. Bars represent one standard deviation. There were no significant differences in ammonium levels among aquaculture and control sites based on two-way ANOVA of water temperature across site type and month. 


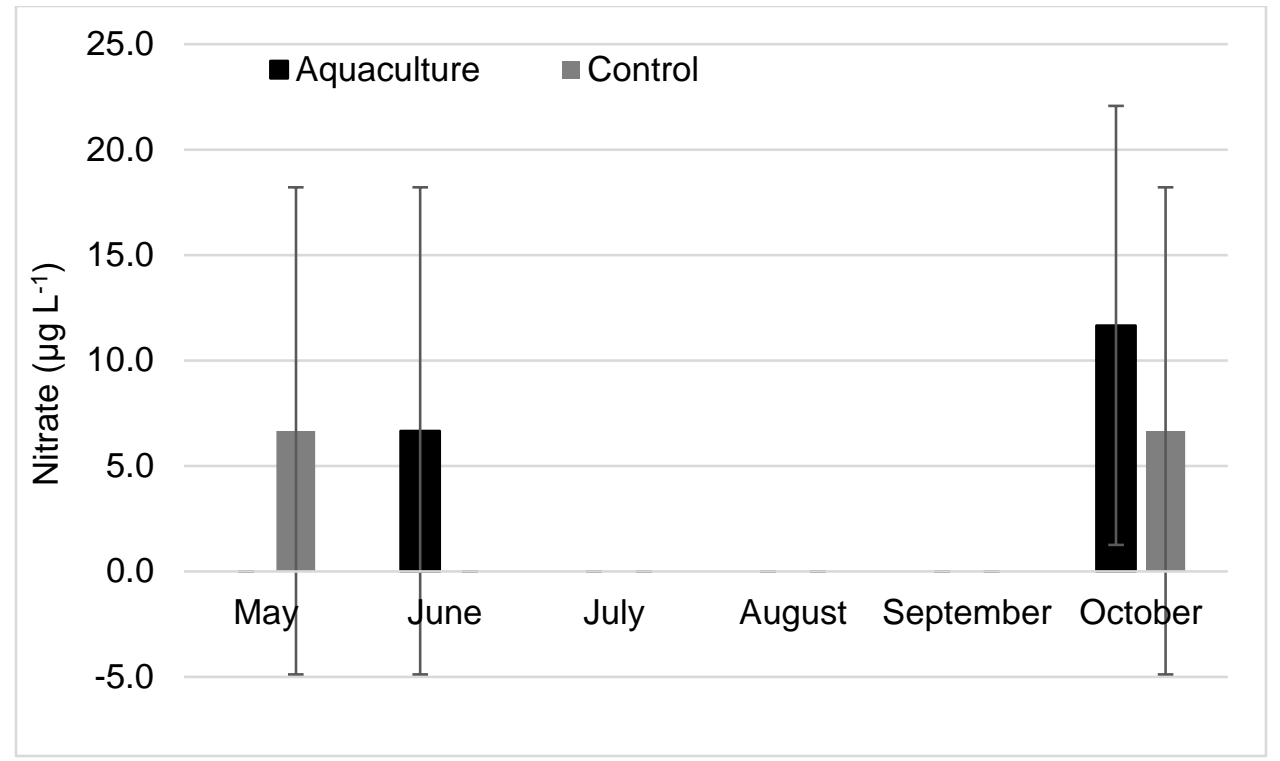

Figure 1.10 Mean $(n=3)$ nitrate levels at aquaculture and control sites within three coastal ponds in southern Rhode Island in 2016. Bars represent one standard deviation. There were no significant differences in nitrate levels among aquaculture and control sites based on two-way ANOVA of water temperature across site type and month. 


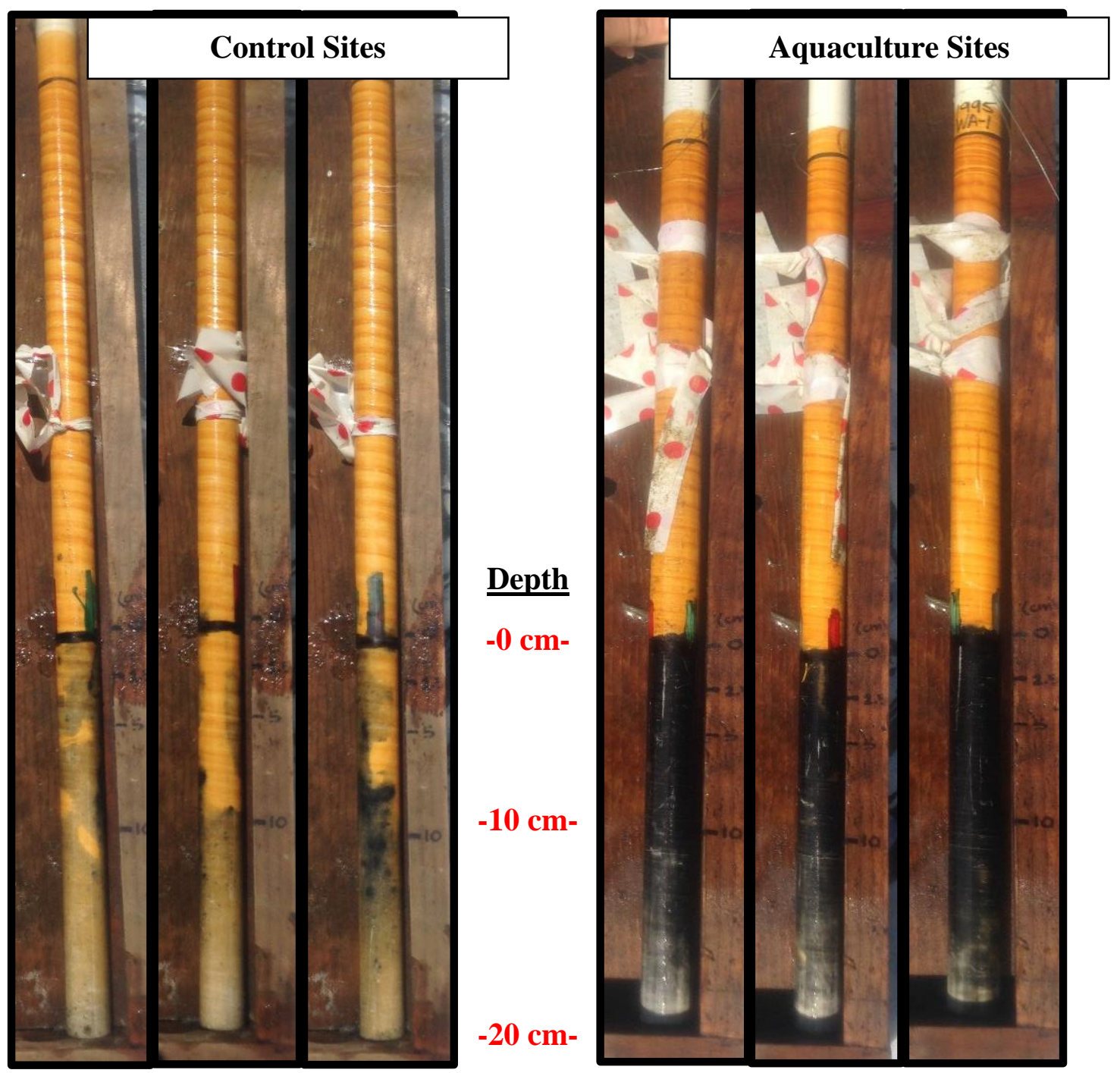

Figure 1.11 Example of IRIS tube reactions from soils at control and aquaculture sites. Minimal black color indicates low sulfide presence within the soil-pore water at control sites. Greater magnitude of black color indicates higher soil pore-water sulfide levels at aquaculture sites. Note that aquaculture site tubes are totally black, compared to control sites which only have few patches black from of Fe monosulfide formation. Depth increments are provided to indicate the full range of the soil profile from 0 to 20 $\mathrm{cm}$. 
Table 1.1 Coastal lagoon properties and characteristics (Pfieffer Herbert, 2007; Beutel, 2015).

\begin{tabular}{cccccc}
\hline $\begin{array}{c}\text { Coastal } \\
\text { lagoon }\end{array}$ & $\begin{array}{c}\text { Area } \\
\text { (acres) }\end{array}$ & $\begin{array}{c}\text { Total area used } \\
\text { for aquaculture } \\
\text { (acres) }\end{array}$ & $\begin{array}{c}\text { Year } \\
\text { breachway } \\
\text { was stabilized }\end{array}$ & $\begin{array}{c}\text { Average } \\
\text { salinity (ppt) }\end{array}$ & $\begin{array}{c}\text { Flushing } \\
\text { time (days) }\end{array}$ \\
\hline Winnapaug & 470 & 6.90 & $1950 \mathrm{~s}$ & 28 & Unknown \\
Ninigret & 1581 & 42.14 & 1952 & 24 & 4.60 \\
Potter & 371 & 8.00 & 1910 & 27 & 1.50 \\
\hline
\end{tabular}




\title{
MANUSCRIPT II: IMPACTS OF OYSTER AQUACULTURE ON SUBAQUEOUS SOILS AND RESIDENT BENTHIC INFAUNA IN RHODE ISLAND COASTAL LAGOONS
}

\author{
In preparation for submission to Soil Science Society of America Journal \\ Chelsea E. Duball ${ }^{1 *}$, Jose A. Amador' ${ }^{1}$, Mark H. Stolt ${ }^{1}$ \\ ${ }^{1}$ Department of Natural Resources Science, University of Rhode Island, 1 Greenhouse \\ Road, Kingston, RI 02881 \\ *Corresponding author: Chelsea Duball \\ Laboratory of Pedology and Soil-Environmental Science \\ University of Rhode Island, Coastal Institute, \\ 1 Greenhouse Rd., Kingston, RI 02881 \\ E-Mail: chelsea_duball@my.uri.edu
}




\begin{abstract}
Oyster aquaculture has expanded considerably in Rhode Island over the past twenty years, especially in coastal lagoons. Most cultured-oysters are grown in racks placed close to the soil surface. Although oysters have been noted to provide beneficial ecosystem services such as providing a food source or improving water quality, few studies have investigated the impacts of oyster aquaculture practices and biodeposition (oyster feces and pseudofeces) on the benthic environment. To assess the environmental impacts of oyster aquaculture to the benthic environment, we measured biodeposition rates and assessed associated changes in subaqueous soil properties and benthic infauna. These studies were conducted at oyster aquaculture sites ranging in age from 5 to 21 years, with accompanying control sites ( 0 years) within three coastal lagoons in southern Rhode Island. The objectives were to: (i) establish rates and $\mathrm{N}$ and $\mathrm{C}$ concentrations of oyster biodeposits, (ii) assess impacts of biodeposits from different oyster stocking densities on soil properties, and (iii) assess impacts of aquaculture practices and biodeposits on soil properties and benthic infauna over the range in timeframes of aquaculture use. Biodeposition rates were a function of oyster size and stocking density, whereby larger and greater amounts of oysters produce significantly more biodeposits than smaller sized or less oysters, per given area. There was also no evidence of $\mathrm{N}$ and $\mathrm{C}$ enrichment within the soil at any stocking density (no oysters, 500 oysters, 2000 oysters), or time point (1, 3.5, 7 days) during our one-week oyster density (biodeposit) study. There were significant differences in bulk density, total $\mathrm{N}$ and $\mathrm{C}$ levels, soil sulfide levels, total infauna, deposit feeders, interface feeders, and parasites across aquaculture and control sites.
\end{abstract}


These trends were not proportional to the age of aquaculture use, suggesting site specific variability may play a key role in determining impacts of aquaculture. Furthermore, low bulk density in the surface soils and common abundance of opportunistic species such as Capitella capitata and Corophium volutator at the majority of aquaculture sites, indicate aquaculture sites likely experience higher levels of disturbance from aquaculture practices. These data suggest oyster biodeposits and physical disturbances from aquaculture practices affect the physical and chemical properties of the soil, causing an increase in infaunal abundance, as well as a shift in the trophic community structure of infauna (favoring opportunistic species and deposit feeders).

\section{INTRODUCTION}

The Eastern oyster (Crassostrea virginica) is an ecosystem engineer that influences coastal environments by interacting with the biological, chemical, and physical components of the ecosystem. Oysters provide various ecosystem services, including food production, water filtration, provision of habitat for epibenthic invertebrates, nutrient cycling, and a fishing resource (Coen et al. 2007; Grabowski and Peterson 2007). Oyster aquaculture has been part of the Rhode Island economy since the beginning of the $20^{\text {th }}$ century, and has expanded considerably since the 1990s, especially in coastal lagoons (RI SMP, 2014). As a result of the economic success of oyster aquaculture, farms continue to expand their range in the coastal lagoons, thus expanding their ecological and environmental impacts. 
Oysters aid in transferring and recycling nitrogen $(\mathrm{N})$ and carbon $(\mathrm{C})$ from the water column to underlying subaqueous soil (referred to as sediment in the marine literature), thus playing a critical role in these coastal ecosystems, particularly within the benthic environment (Asmus and Asmus 1993; Coen and Grizzle 2007; Dame 2012; Higgins et al. 2013). Oysters aid in nitrogen and carbon cycling between water and soil - known as benthic-pelagic coupling - by removing particulate organic matter via filter-feeding and transfer it to the soil as feces and pseudofeces, collectively known as biodeposits. The $\mathrm{N}$ and $\mathrm{C}$ in biodeposits are consumed by benthic infauna (benthic organisms that live within the soil), accumulate in the soil, or are transformed to dissolved organic forms, followed by mineralization and/or denitrification (Newell et al., 2002; Giles and Pilditch, 2006; Dame, 2012). Biodeposition rates vary widely by oyster species, location, and in response to environmental factors, including availability of food (phytoplankton), water flow, and temperature (Table 2.1). When biodeposition rates are higher than the rate at which they can be processed in the soil, excess $\mathrm{N}$ and $\mathrm{C}$ may accumulate in the benthic environment (Black, 2001; Magill et al., 2006). An excess of $\mathrm{N}$ and $\mathrm{C}$ can lead to over-fertilization and reduced dissolved oxygen content in the soil (Prins et al., 1998). If the population density of farmed oysters is too high, biodeposits could also overwhelm the capacity of soils to support nitrification, preventing $\mathrm{N}$ removal via denitrification (Rice, 2000). These effects are a particular concern with "off-bottom" aquaculture practices that place oyster gear in close contact with the soil surface (Figure 2.1). Because most oyster farms in Rhode Island use cages, trays, or rack and bag aquaculture systems, where oysters interact 
closely with the soil, proper assessment of site conditions become critical for these farming systems, particularly in regard to soil type (RI SMP, 2014).

Data on soil properties can be applied to make land use and management decisions in coastal environments, including eelgrass restoration (Bradley and Stolt, 2006; Pruett, 2010), C accounting (Jespersen and Osher, 2007), acidification control (Still and Stolt, 2015), dredging (Salisbury, 2010) and oyster aquaculture (Salisbury, 2010). Shallow-water soils are studied by identifying the collection of horizons (layers) that are linked both with depth and across the landscape (Demas et al., 1996; Demas and Rabenhorst, 1999; Bradley and Stolt, 2003). This pedological approach is useful because it characterizes a soil based on a combination of physical and biogeochemical properties, as opposed to a single component or parameter (i.e. grain size). Thus, alterations to the soil as result of shellfish aquaculture (e.g. biodeposit inputs) and disturbance from aquaculture practices are expected to be reflected as changes in soil properties.

As soil properties change with the impact of oyster aquaculture, resident benthic infauna respond to changes in their surrounding environment. Benthic infauna are useful indicators of impact because: (i) they are sedentary and readily respond to local environmental changes; (ii) they incorporate a wide range of physiological tolerances, living positions, feeding modes and trophic interactions; (iii) assemblages respond relatively quickly to habitat disturbances; and (iv) they are important components of aquatic food webs that affect transport and cycling of nutrients (Brooks et al., 2006; Bilyard, 1987). The distribution of most benthic assemblages also appears to be related to differences in soil type, temperature, salinity, primary 
productivity, depth, physical disturbance, and historical disturbance (Snelgrove, 1998; Paolucci, 2017). Thus, the incorporation of benthic infauna and subaqueous soil data could prove to be a powerful approach to evaluating the impacts of oyster aquaculture on coastal lagoons.

In this study, we investigated the impacts of oyster biodeposits on subaqueous soil properties and resident benthic infauna of three coastal lagoons in southern Rhode Island. Soil, infauna, and biodeposit samples were collected in 2015 and 2016 between May and November, when water temperatures support peak oyster production and biodeposition. We assessed the impacts of oyster aquaculture by: (i) establishing rates, and $\mathrm{N}$ and $\mathrm{C}$ concentrations, of biodeposits from cultured-oysters; (ii) analyzing impacts on soil and infauna at various oyster stocking densities (oyster density experiment); and (iii) analyzing impacts on soil and infauna at various durations of continuous aquaculture use (0-21 years). We hypothesized that larger oysters and greater oyster stocking densities would produce more biodeposits, thus increasing $\mathrm{N}$ and $\mathrm{C}$ inputs to the soil, compared to smaller oysters and lower stocking densities. We expected to see higher levels of $\mathrm{N}$ and $\mathrm{C}$ in the upper $2 \mathrm{~cm}$ of the soil as a result of increased biodeposition from higher stocking densities. Under long-term durations of aquaculture use, we expected $\mathrm{N}$ and $\mathrm{C}$ inputs from biodeposits to exceed the capacity of the soil and biological community to process these, resulting in significant changes to physical and chemical properties of the soil, and resident infaunal communities. As a result, we expected that aquaculture sites would have lower bulk density, higher soil sulfide levels, higher soil $\mathrm{N}$ and $\mathrm{C}$ concentrations (and these levels would occur deeper in the soil profile), and a greater abundance of infauna with changes to trophic 
community structure (favoring deposit feeding opportunistic infauna) when compared to control sites. In addition, we expected impacts from physical disturbances on the soils and infauna to increase the longer a site has been used for aquaculture practices.

\section{METHODS}

\section{$\underline{\text { Study Sites }}$}

We established study sites in three coastal lagoons on the south coast of Rhode Island: Ninigret (NP), Winnapaug (WP), and Potter Ponds (PP) (Figure 2.2). All of the subaqueous soils were mapped for these ponds within the context of the MapCoast Partnership (Payne and Turenne, 2009). We utilized these soil maps to select appropriate study sites all located on the same soil type (Nagunt sand: mixed, mesic Sulfic Psammowassents), and in shallow washover fan areas.

To establish biodeposition rates and impacts of aquaculture over time, we selected three oyster aquaculture farms (also known as leases), each located in one of the three ponds. To study aquaculture impacts over time, we determined the specific age of sites within each aquaculture lease using a "time-hop" function available in Google Earth maps, which allowed us to look back on aerial imagery from the early 1990's to present day. A total of seven aquaculture age sites were established: one in NP (5 years-old), three in WP $(6,13$, and 21 years-old), and three in PP $(6,8$, and 12 years old). Two aquaculture sites in different ponds were six years-old, and were designated as 6(PP) and 6(WP) based on their location. In addition, an area 300-600 $m$ from any aquaculture site - that had never been used for aquaculture - was sampled 
and used as a control site (0 years-old). In August of 2016 we conducted the oyster density experiment adjacent to the control sites in NP (Figure 2.2).

\section{$\underline{\text { Sample Collection and Analyses }}$}

In our first experiment, we examined changes in soil properties and benthic infauna to assess the environmental impacts of oyster aquaculture as a function of continuous aquaculture use. Within each aquaculture age site, four soil cores were extracted from the upper $20 \mathrm{~cm}$ of the soil, directly adjacent to an active oyster rack, in three plots per age site. Control sites were sampled in the same manner as aquaculture sites. Soil cores were collected in early summer of 2015 and 2016 as described by Payne (2007), using a 10-cm-diameter aluminum core, manually forced down to a depth of $20 \mathrm{~cm}$. Three soil cores were composited by depth increments of $0-2.5 \mathrm{~cm}$, $2.5-5 \mathrm{~cm}, 5-10 \mathrm{~cm}$, and $10-20 \mathrm{~cm}$, frozen at $-15^{\circ} \mathrm{C}$, and later analyzed for soil properties. A fourth core was obtained and the full volume $\left(1570 \mathrm{~cm}^{3}\right)$ of soil in the core was sieved (0.5-mm mesh) for resident benthic infauna analysis. Infauna that remained in the sieve were preserved in $70 \%$ ethanol, dyed with rose Bengal to aid identification, and stored at room temperature for later identification and sorting (Dye, 2006).

We analyzed soil samples for bulk density, particle size distribution (PSD), incubation $\mathrm{pH}(\Delta \mathrm{pH})$, electrical conductivity, total carbon $(\mathrm{C})$, and total nitrogen $(\mathrm{N})$. Bulk density samples were collected separately using a $393-\mathrm{cm}^{3}$ core and divided into the same depth increments as the larger soil cores. To calculate the bulk density for each depth increment, oven-dry $\left(105^{\circ} \mathrm{C}\right)$ soil weight was divided by the original soil 
volume, and corrected for coarse fragment content. Particle size distribution (PSD) was carried out using $10 \mathrm{~g}$ of oven-dried soil, using a modification of the method of Gee and Bauder (1986). Preliminary analysis found limited variation in particle size within any depth increment of the upper $20 \mathrm{~cm}$, therefore PSD was only determined for the upper $5 \mathrm{~cm}$ of the soil profile, where most effects of disturbance and infauna were expected. Soil samples were wet-sieved $(0.05 \mathrm{~mm})$ to separate sand from the finer silt and clay particles. The sand fraction was oven-dried, weighed, and processed through a nest of sieves (2-mm, 1-mm, 0.5-mm, $0.25 \mathrm{~mm}, 0.1-\mathrm{mm}$, and $0.05-\mathrm{mm}$ mesh size) to separate the various size fractions of sands (Soil Survey Staff, 2004). Electrical conductivity was measured using a 5:1 vol/vol, soil: deionized water slurry, with an Oakton WD-35607 (Vernon Hills, IL) hand-held conductivity meter (Pruett, 2010). Incubation $\mathrm{pH}$ measurements, used to test for the presence of soil sulfides, were made on samples using a 1:1 vol/vol, soil: deionized water slurry and incubated at room temperature for 16 weeks, and $\mathrm{pH}$ was measured once a week (Soil Survey Staff, 2004). Under incubation conditions soil sulfides can oxidize to form sulfuric acid. Thus, we used the resulting drop in $\mathrm{pH}$ as a proxy for soil sulfide levels, assuming all soils had similar acid neutralizing capacity. We determined the total $\mathrm{N}$ and $\mathrm{C}$ content of the soil by using a CE Instruments Model NC2100 (Lakewood, NJ) elemental analyzer, on 10-12 $\mu \mathrm{g}$ of soil sample which was pretreated with $1.0 \mathrm{M} \mathrm{HCl}$ to remove calcium carbonate, rinsed three times with DI water, dried, ground with a mortar and pestle and passed through a $0.25 \mathrm{~mm}$ mesh sieve (Midwood and Button, 1998; Payne, 2007). 
Benthic infauna were first identified to the species level. Each preserved sample was observed under a dissecting microscope to identify organisms based on anatomical features, using Bousfield (1973), Weiss and Bennett (1995), Pollock (1998), and WoRMS Editorial Board (2017) for guidance. A fraction of infaunal samples were confirmed by an expert taxonomist for identification accuracy. Individual organisms were later sorted into functional feeding groups (Table 2) based on feeding guilds and ecological descriptions reported in the literature. Using population count data, we also calculated the functional diversity of each site using the Shannon-Weiner Diversity Index (SWDI):

$$
\mathrm{H}=-\Sigma\left[\left(\mathrm{p}_{\mathrm{i}}\right) * \ln \left(\mathrm{p}_{\mathrm{i}}\right)\right]
$$

where $\mathrm{H}=$ the final SWDI index value, that results from taking the negative summation $(-\Sigma)$ of, $p_{i}=$ the number of individuals within each functional feeding group divided by the total number of infauna for that sample, multiplied by the natural $\log$ of $\mathrm{p}_{\mathrm{i}}$. Higher values of $\mathrm{H}$ are representative of more diverse communities.

For the second study, we determined rates of biodeposition for oysters ranging 6 to $13 \mathrm{~cm}$ in size and at stocking densities of 540 to 870 oysters $\mathrm{m}^{-2}$. The amount of biodeposits produced from specific densities of oysters per unit of time was determined from actively farmed racks of oysters within each of the three ponds using a modification of Higgins et al. (2011) approach. Two metal pans, $23 \mathrm{~cm}$ x $23 \mathrm{~cm}$ x 5 $\mathrm{cm}$, were directly attached to the bottom of the oyster racks, and a rack containing no oysters was placed in a control area. Pans were left in place for three days to collect biodeposits, after which samples were collected and dried $\left(60{ }^{\circ} \mathrm{C}\right)$ to determine total dry weight. Weights recorded for the control sites were negligible; thus, we assumed 
all the mass in the trays below the oyster racks were a majority biodeposits, with some seston included (negligible after drying), which accounts for the bulk of the particles that naturally settle beneath aquaculture racks, as shown by Newell et al. (2005). We used the total dry weight of biodeposits, cross-sectional area of the collection pan, oyster shell length, rack dimensions, and number of oysters measured for each rack, to calculate both the rate of biodeposits produced per area $\left(\mathrm{g} \mathrm{DW} \mathrm{m}^{-2} \mathrm{~d}^{-1}\right)$, and per oyster (g DW oyster ${ }^{-1}$ day $^{-1}$ ). A portion of the biodeposit samples was also dried at $60{ }^{\circ} \mathrm{C}$, and saved for total $\mathrm{N}$ and $\mathrm{C}$ analysis.

The third part of this study aimed to investigate the impacts of oyster stocking density to the soil environment, via an oyster density experiment. Based on field measurements of oyster stocking densities and biodeposition rates, mass loading rates were determined for biodeposits representative of high (2000 oysters $\left.\mathrm{m}^{-2}\right)$, and average (500 oysters $\mathrm{m}^{-2}$ ) oyster stocking densities, for near-market size oysters $(6-\mathrm{cm})$. We established triplicate plots in an area of NP not previously used for aquaculture (Figure 2.2). Each plot contained three subplots which represented biodepositional inputs produced from no oysters (control), an average stocking density, and a high stocking density. Biodeposits for this experiment were collected from an upwelling system where oysters were contained in a confined environment (Figure 2.1). After collection, biodeposits were allowed to settle at $4{ }^{\circ} \mathrm{C}$ for one day and the water was decanted. The concentrated biodeposits were distributed into $23 \times 23$ x $5 \mathrm{~cm}$ aluminum pans and frozen at $-15{ }^{\circ} \mathrm{C}$. Sub-samples were taken from each individual pan and analyzed for total $\mathrm{C}$ and $\mathrm{N}$, following similar procedure for soil analysis outlined by (Midwood and Button, 1998; Payne, 2007). The concentrated 
biodeposits, representing weekly inputs from different oyster densities, were applied to the soil surface in August of 2016. We applied the biodeposits in a frozen state still in the pan. In order to allow the biodeposits to settle onto the soil surface and minimize losses to the water column, the pans were flipped over, carefully place on the soil surface, and $0.5 \mathrm{~kg}$ weight was place on top of the pan to keep it in place. In addition, to diminish the impact of water flow on the biodeposit inputs, a plastic frame was inserted around each experimental sub-plot, and covered with a 1-mm-mesh lid. Soils were sampled before application, and 1,3.5, and 7 days after application (the pan was removed after one day). Soils were sampled using a 2 -cm diameter plastic syringe, inserted into the upper $2 \mathrm{~cm}$ of the soil profile. Triplicate soil samples were composited together according to sub-plot (control, average, high), plot, and time point, and later analyzed for total $\mathrm{N}$ and $\mathrm{C}$ following methods of (Midwood and Button, 1998; Payne, 2007).

\section{$\underline{\text { Statistical analysis }}$}

We used SigmaPlot v.11.2 software for all statistical analyses (Systat Software Inc., San Jose, CA). Data that failed tests of normality and equal variance were Logtransformed. Soil properties were compared across all sites, ranging from 0 (control) to 21 years of aquaculture, and depth increments, using two-way analysis of variance (ANOVA), with a significance level of $\alpha=0.050$. We conducted multiple comparisons versus a control group using the Holm-Sidak method, in order to compare the control site ( 0 years) values to aquaculture age site (5 to 21 years) values, with a significance level of $\alpha=0.05$. 
Total abundance, functional feeding group abundance, and diversity of infauna were compared across all sites (ranging 0 to 21 years of aquaculture) using a KruskalWallis one-way ANOVA based on ranks. Multiple comparisons versus a control group were conducted using Dunn's method, to compare control site median values (0 years) to median values at each aquaculture age site (5 to 21 years), with a significance level of $\alpha=0.05$. We used Spearman Rank Order Correlations to assess the relationships between total abundance of infauna and soil properties (bulk density, total $\mathrm{N}$, total $\mathrm{C}, \Delta \mathrm{pH})$, with a significance level of $\alpha=0.05$.

\section{RESULTS}

$\underline{\text { Soil and site characteristics }}$

Nagunt sand soils had 91-98\% sand-sized particles, across all aquaculture and control sites (Appendix 1). Further analysis of sand particle size showed the largest portion of the sand fraction $(\sim 50 \%$ or greater) was comprised of fine $(0.1-0.25-\mathrm{mm})$ to medium $(0.25-0.5-\mathrm{mm})$ sized sand particles. Electrical conductivity ranged from 1.87 to $2.88 \mathrm{mS} \mathrm{m}^{-1}$ for all sites (Appendix 1).

Bulk density ranged from 0.97 to $1.60 \mathrm{~g} \mathrm{~cm}^{-3}$ (Figure 2.3 and Appendix 1). There was a significant difference $(\mathrm{P}<0.001)$ in bulk density among sites, and bulk density of the control sites was only significantly different from the 13 -year aquaculture site (Figure 2.3). Bulk density was also significantly different $(\mathrm{P}<0.001)$ among depth increments, regardless of aquaculture age; specifically, the surface soils (0-2.5 cm depth increments) had lower bulk density than soils at greater depths $(2.5-5$ 
$\mathrm{cm}, 5-10 \mathrm{~cm}$, and 10-20 cm depth increments) at 50\% of all sites. Aquaculture sites used for $6(\mathrm{PP}), 8$, and 12 years had the lowest average $\left(<1.2 \mathrm{~g} \mathrm{~cm}^{-3}\right)$ surface $(0-2.5 \mathrm{~cm}$ depth) bulk density.

\section{$\underline{\text { Biodeposit production and } \mathrm{N} \text { and } \mathrm{C} \text { concentration }}$}

We measured rates of biodeposition from a range of different sized oysters $(6$, 10 , and $13 \mathrm{~cm}$ ) to determine the amount of $\mathrm{N}$ and $\mathrm{C}$ being transported to the soil when water temperature was warmest (August of 2015 and 2016). Rates of biodeposition were significantly and positively correlated with oyster size $\left(\mathrm{P} \leq 0.05, \mathrm{r}^{2}=0.8724\right)$ (Figure 2.4). The largest oysters $(13-\mathrm{cm})$ had the highest average daily rate of biodeposition at $0.64 \mathrm{~g} \mathrm{DW}$ oyster ${ }^{-1}$ day $^{-1}$ (Table 2.1). Smaller oysters (6-cm) had a lower rate $\left(0.10-0.13 \mathrm{~g} \mathrm{DW}_{\text {oyster }}{ }^{-1} \mathrm{day}^{-1}\right)$ (Table 2.1$)$. The biodeposition rate for medium size oysters $(9-\mathrm{cm})$ was $0.23 \mathrm{~g} \mathrm{DW}_{\text {oyster }}{ }^{-1}$ day $^{-1}$ (Table 2.1). Biodeposition rates also varied as a function of oyster size and oyster stocking density, and the rate of biodeposition ranged from 68.86 to $82.33 \mathrm{~g} \mathrm{DW} \mathrm{m}^{-2}$ day $^{-1}$ for 6-cm oysters, 202.33

$\mathrm{g} \mathrm{DW} \mathrm{m}^{-2} \mathrm{day}^{-1}$ for $10-\mathrm{cm}$ oysters, and $346.47 \mathrm{~g} \mathrm{DW} \mathrm{m}^{-2}$ day $^{-1}$ for $13-\mathrm{cm}$ oysters (Table 2.1). $\mathrm{N}$ and $\mathrm{C}$ concentration of biodeposits across all oyster sizes and sampling years had a mean \pm S.D. total $\mathrm{N}$ and $\mathrm{C}$ concentration of $10.4 \pm 2.6 \mathrm{~g} \mathrm{~kg}^{-1}$ and $82.5 \pm$ $12.6 \mathrm{~g} \mathrm{~kg}^{-1}$, respectively.

\section{Effects of biodeposition on accumulation of $\mathrm{N}$ and $\mathrm{C}$ in the soil}

Using our in situ biodeposition rates for near-market size oysters (6-cm), we conducted an experiment to simulate the impact of oyster aquaculture to the soil at 
different stocking densities. The aim of this experiment was to measure potential increases in the level of $\mathrm{N}$ and $\mathrm{C}$ in the soils after short-term (up to one week) exposure to biodepositional inputs. For this experiment, each treatment simulated the impact of various stocking densities, using representative amounts of biodeposits produced in one week from a control (no oysters), an average density (500 oysters $\mathrm{m}^{-}$ ${ }^{2}$ ), and a high density (2000 oysters $\mathrm{m}^{-2}$ ). Biodeposits had $\mathrm{N}$ and $\mathrm{C}$ concentrations averaging (mean $\pm \mathrm{SD}$ ), $14.79 \pm 0.45 \mathrm{~g} \mathrm{~kg}^{-1}$ and $114.67 \pm 2.14 \mathrm{~g} \mathrm{~kg}^{-1}$, respectively, and were within range of $\mathrm{C}$ and $\mathrm{N}$ levels from the in situ biodeposition study. Samples were collected from the upper $2 \mathrm{~cm}$ of the soil after $0,1,3.5$, and 7 days. There was no change in $\mathrm{N}$ or $\mathrm{C}$ concentrations in the soil at any point during the one-week sampling period, regardless of each sub-plot treatment (Figure 2.5).

In addition to the oyster density experiment, we compared $\mathrm{N}$ and $\mathrm{C}$ concentration in samples from the upper $20 \mathrm{~cm}$ of soil at all aquaculture and control sites. Levels of total $\mathrm{N}$ ranged between 0.036 and $0.370 \mathrm{~g} \mathrm{~kg}^{-1}$ for all sites (Figure 2.6). There was a statistically significant difference in $\mathrm{N}$ levels among all sites ranging from 0 to 21 years of aquaculture; with $\mathrm{N}$ levels at control sites significantly different from the 12-year (at 10-20 cm) and 13-year (at 2.5-5 cm) aquaculture sites (Figure 2.6). There were also significant differences $(\mathrm{P} \leq 0.001)$ in $\mathrm{N}$ levels among soil depths in aquaculture and control sites; specifically, $\mathrm{N}$ levels were significantly lower in the surface soils $(0-2.5 \mathrm{~cm}$ and $2.5-5 \mathrm{~cm}$ depths $)$ compared to greater soil depths $(5-10 \mathrm{~cm}$ and $10-20 \mathrm{~cm})$ at 5 out of 8 sites. The highest level of $\mathrm{N}$ was measured at the aquaculture site used for 12 years, which had a concentration of $0.37 \mathrm{~g}$ 
$\mathrm{kg}^{-1}$ at $10-20 \mathrm{~cm}$ depth. The lowest $\mathrm{N}$ levels were observed in the 0-2.5 $\mathrm{cm}$ depth of the aquaculture site used for 13 years, with a concentration of $0.04 \mathrm{~g} \mathrm{~kg}^{-1}$.

Total C levels ranged between 0.54 and $4.73 \mathrm{~g} \mathrm{~kg}^{-1}$ (Figure 2.7). Differences in levels of $\mathrm{C}$ were statistically significant $(\mathrm{P} \leq 0.001)$ among all sites. $\mathrm{C}$ levels at control sites were statistically different $(\mathrm{P} \leq 0.05)$ than levels at the 6(PP) $($ at $0-5 \mathrm{~cm})$, 6(WP) (at 2.5-5 cm), and the 12-year (at 0-5 cm, and 10-20 cm) aquaculture sites (Figure 2.7). There were also significant differences $(\mathrm{P} \leq 0.001)$ in $\mathrm{C}$ levels at different depth increments, across all sites; specifically, there was lower $\mathrm{C}$ levels in the surface soils $(0-2.5 \mathrm{~cm}$ and $2.5-5 \mathrm{~cm})$ compared to greater soil depths $(5-10 \mathrm{~cm}$ and $10-20 \mathrm{~cm}$ ) for 6 out of 8 sites. The highest level of $\mathrm{C}$ was observed in the $10-20 \mathrm{~cm}$ depth increment of the soil at the 12-year-old aquaculture site. The lowest level of C was observed within the $0-2.5 \mathrm{~cm}$ depth increment of the 13 -year-old aquaculture site.

\section{Effects of aquaculture age on soil sulfide levels}

During moist incubation of soils, sulfides are oxidized to form sulfuric acid, lowering the $\mathrm{pH}$ of the samples. We use this change $(\Delta)$ in $\mathrm{pH}$ as a proxy for the level of sulfides present in the soil. Incubation $\mathrm{pH}$ measurements indicated that soils at both aquaculture and control sites contained enough sulfides to cause a decrease in $\mathrm{pH}$ (Figure 2.8). $\Delta \mathrm{pH}$ ranged between -0.3 and -4.0 across all sites. Differences in $\Delta \mathrm{pH}$ were statistically significant $(\mathrm{P} \leq 0.05)$ across all sites, however, no aquaculture sites were significantly different from the control sites, when accounting for the effects of depth. There was no significant difference $(\mathrm{P}=0.158)$ in $\Delta \mathrm{pH}$ among depth increments. Aquaculture sites used for 5 and 8 years had the lowest $\Delta \mathrm{pH}$ across all 
depths (Figure 2.8). Highest $\Delta \mathrm{pH}$ values were observed at the aquaculture sites used for 13 and 21 years across all depths.

\section{Effects on benthic infauna}

We identified the benthic macroinvertebrates within the soils to examine changes in abundance, trophic level, or diversity. Benthic infauna were identified to the species and subsequently sorted into functional feeding groups to understand their interactions within the soil and trophic levels (the number of steps an organism is from the start of the food chain, i.e. deposit feeders are a step up from primary producers but lower than predators on the food chain). We identified a total of 64 species, belonging to seven different functional feeding groups (deposit feeders, interface feeders, suspension feeders, predators, grazers, scavengers, parasites) across all sites (Table 2.2 and Appendix 2). The five most abundant species at each site comprised between 67 and $74 \%$ of the total infauna (Table 2.3). There was noticeable overlap among the five most abundant species found at aquaculture sites (in general) and control sites, such as Diploydora commensalis, Prionospio dubia, and Capitella capitata. Aquaculture sites had nearly double the abundance of the deposit-feeding opportunistic species C. capitata compared to control sites, and the relative majority (23\%) of infauna at aquaculture sites was comprised of Corophium volutator, another opportunistic species. There was also higher relative abundance of deposit feeders at aquaculture sites (in general) compared to control sites (Figure 2.9).

We conducted further statistical analyses to identify specific trends among infauna at different aquaculture age sites. There was a statistically significant 
difference $(\mathrm{P}=0.009)$ in total abundance of infauna among all sites. Control sites had significantly lower total abundance, compared to the 6(PP) and 8-year aquaculture sites. Total abundance of infauna was higher at all aquaculture sites $>5$ years-old (Figure 2.10). Additionally, functional feeding group analyses showed populations of deposit-feeders, interface feeders, and parasites were significantly different across all sites (Figure 2.10). Deposit feeder populations were significantly larger at the 6(PP), 6(WP), and 8-year aquaculture sites compared to control sites. Interface feeder populations also were significantly larger at the 6(PP) and 8-year aquaculture sites compared to control sites. No other functional feeding group abundance was statistically different between aquaculture age sites and control sites.

We also analyzed the relationships among infaunal communities and if infauna were influenced by specific environmental factors. Shannon-Wiener diversity index values ranged from 0.9 to 1.3 (Figure 2.11 ). There was no statistically significant difference $(\mathrm{P}=0.404)$ in the diversity of infauna, across all sites. There was also no significant correlation $(\mathrm{P}>0.05)$ between total abundance of infauna and bulk density, $\Delta \mathrm{pH}, \mathrm{N}$ pools, or C pools.

\section{DISCUSSION}

Oysters are effective filter feeders, removing nutrients, including $\mathrm{N}$, and suspended materials such as organic matter from the water column. This was clear from our biodeposition data which showed that, on average, 1 to $2 \mathrm{~g} \mathrm{~N}$ and 6 to $17 \mathrm{~g} \mathrm{C}$

is deposited on the soil surface from each $1 \mathrm{~m}^{-2}$ rack per day, as the oysters remove the 
$\mathrm{N}$ and $\mathrm{C}$ from the water column. Larger oysters also produce more biodeposits

(Figure 2.4). Data from the literature suggest that our rates are representative of oysters in general (Table 2.1). For example, Haven and Morales-Alamo (1966) reported similar ranges for biodeposition rates of $C$. virginica, and Mitchell (2006) reported similar rates for near-market size $(6-\mathrm{cm})$ oysters (Table 2.1$)$. The concentration of $\mathrm{N}$ and $\mathrm{C}$ in biodeposits collected in situ for near-market size oysters was $10.4 \pm 2.6 \mathrm{~g} \mathrm{~N} \mathrm{~kg}^{-1}$ and $82.5 \pm 12.6 \mathrm{~g} \mathrm{C} \mathrm{kg}^{-1}$.

Biodeposits were enriched with $40 \%$ more $\mathrm{N}$ and $24 \%$ more $\mathrm{C}$ than the highest level of $\mathrm{N}$ and $\mathrm{C}$ found in the soil at any aquaculture site (Figure 2.6 and Figure 2.7). Our values are also comparable to data reported by Newell et al. (2005), who found N and $\mathrm{C}$ concentrations of $6.9 \mathrm{~g} \mathrm{~N} \mathrm{~kg}^{1}$ and $49.4 \mathrm{~g} \mathrm{C} \mathrm{kg}^{-1}$ for biodeposit inputs. Together, our results suggest oyster aquaculture adds substantial amounts of biodeposits - and associated $\mathrm{C}$ and $\mathrm{N}-$ to the benthic environment.

We attempted to measure the processing of $\mathrm{N}$ and $\mathrm{C}$ in the biodeposits added to the soil, using our one-week oyster density experiment. Contrary to our original hypothesis, no accumulation of $\mathrm{N}$ or $\mathrm{C}$ was observed, even at biodeposition rates corresponding to high oyster stocking densities (Figure 2.5). If the $\mathrm{N}$ and $\mathrm{C}$ in biodeposits had behaved conservatively, we would have expected the concentration of $\mathrm{N}$ and $\mathrm{C}$ to increase by $0.8 \mathrm{~g} \mathrm{~N} \mathrm{~kg}^{-1}$ soil and $6.6 \mathrm{~g} \mathrm{C} \mathrm{kg}^{-1}$ soil for the high addition, and $0.2 \mathrm{~g} \mathrm{~N} \mathrm{~kg}^{-1}$ soil and $1.6 \mathrm{~g} \mathrm{C} \mathrm{kg}^{-1}$ soil for the average addition rate, after one day (Appendix 3). These changes would be easily measured with our methods. A similar study conducted in New Brunswick, Canada, found that even though considerable organic matter was added to the soil from oyster biodeposition, there was no 
indication of organic enrichment in the substrate (Mallet et al., 2006). Since there was no measurable enrichment, we assumed that processes in the upper $2 \mathrm{~cm}$ of the benthic zone accounted for the loss of $5.4 \mathrm{~g} \mathrm{~N} \mathrm{~m}^{-2}$ and $44.3 \mathrm{~g} \mathrm{C} \mathrm{m}^{-2}$ (average application rate) and, $21.6 \mathrm{~g} \mathrm{~N} \mathrm{~m}^{-2}$ and $177.1 \mathrm{~g} \mathrm{C} \mathrm{m}^{-2}$ (high application rate) in a day (Appendix 3). A number of different mechanisms - such as denitrification, translocation by infauna, and infaunal bioturbation - could explain losses of $\mathrm{N}$ and $\mathrm{C}$ within the soil.

Other studies have looked at $\mathrm{N}$ losses in shallow coastal sediments, because of concerns with estuarine eutrophication. Lamontagne and Valiela (1995) reported rates of denitrification for sediments in shallow estuaries as high as $0.24 \mathrm{~g} \mathrm{~N} \mathrm{~m}^{-2} \mathrm{~d}^{-1}$. In Ninigret Pond, RI, Humphries et al. (2016) reported denitrification rates in sediments under oyster reefs and oyster aquaculture as high as $0.20 \mathrm{~g} \mathrm{~N} \mathrm{~m}^{-2} \mathrm{~d}^{-1}$. Our estimates of $\mathrm{N}$ loss, however, are one order of magnitude higher than those accounted for by denitrification rates reported in the literature. Additional losses of $\mathrm{N}$, as well as $\mathrm{C}$, could be due to infaunal translocation, because we observed high numbers of burrowing infauna at the surface of all plots receiving biodeposits when we sampled after one day.

One of our hypotheses was that sites under long-term aquaculture use would have significant enrichment of $\mathrm{N}$ and $\mathrm{C}$ in the soil as a result of increased biodeposition. Increases in $\mathrm{N}$ and $\mathrm{C}$ levels were not proportional with duration of aquaculture use; however, the control had significantly lower levels of $\mathrm{N}$ than the 12year site (at $10-20 \mathrm{~cm}$ ), and lower $\mathrm{C}$ than the 6(PP) (at 0-5 cm) and 12-year (at 0-5 cm, and $10-20 \mathrm{~cm}$ ) aquaculture sites. Additionally, the control site also had significantly higher $\mathrm{N}$ than the 13-year (at 2.5-5 cm) site, and higher $\mathrm{C}$ than the 6(WP) (at 2.5-5 
$\mathrm{cm}$ ). However, if we look at $\mathrm{N}$ and $\mathrm{C}$ in terms of pools (mass per area/volume) for the full $20 \mathrm{~cm}$ soil profile, we see that the size of the overall $\mathrm{N}$ and $\mathrm{C}$ pools is not proportional to the duration of aquaculture use (Figure 2.12). This suggests that $\mathrm{N}$ and $\mathrm{C}$ enrichment, is controlled in part by factors other than duration of aquaculture use. Kellogg et al. (2014) suggested that long-term accumulation rates for $\mathrm{N}$ and $\mathrm{C}$ in sediments are likely site-specific, depending on aquaculture practices such as stocking density, position within the water column, maintenance protocols, and harvest techniques. Specific aquaculture practices may also influence deposition rates, soil biogeochemistry, and soil resuspension (Kellogg et al., 2014). Therefore, site specific effects and processes could provide reasoning to the dynamics of $\mathrm{N}$ and $\mathrm{C}$ within the soil.

Physical disturbances could help explain the dynamics of $\mathrm{N}$ and $\mathrm{C}$ within the soil profile, at both aquaculture and control sites. Our results showed bulk density was significantly different across all sites, and at different depth ranges (Figure 2.3). Furthermore, surface bulk density (0-2.5 cm depth) was lower than greater soil depths (2.5-5 cm, 5-10 cm, and 10-20 cm depths) at 50\% of sites. These results suggest bulk density varied among all sites, although it should be noted that lower surface bulk density was typically observed at aquaculture sites, indicating potential effects of disturbance. Shallow areas of the lagoons are convenient sites for both recreational users and oyster farmers and, as a result, the soil surface experiences frequent physical disturbances via foot traffic and/or recreational activities, such as wild shellfish harvesting and dropping of boat anchors. Soil disturbances are common at aquaculture and control sites, but typically occur more frequently at aquaculture sites 
due to routine maintenance of heavy aquaculture gear and foot traffic from farm workers (De Grave et al., 1998; Forrest and Creese, 2006). These disturbances cause resuspension of the surface soils and compaction of the underlying soil over time. Compaction, in turn, increases the potential for organic $\mathrm{N}$ and $\mathrm{C}$ to accumulate at greater depths. Our results suggest aquaculture practices may have a positive effect on the soil by facilitating sequestration of greater concentrations of $\mathrm{N}$ and $\mathrm{C}$ deeper into the soil.

Lower concentrations of $\mathrm{N}$ and $\mathrm{C}$ in the surface soil could be explained by infaunal translocation, specifically at aquaculture sites. We observed significantly higher abundance of infauna and deposit feeding worms in some aquaculture sites compared to control sites (Figure 2.10). Additionally, we saw lower concentrations of $\mathrm{N}$ (at 4 out of 7 aquaculture sites) and $\mathrm{C}$ (at 5 out of 7 aquaculture sites) at 0-2.5 and 2.5-5 cm depths, compared to the lower $15 \mathrm{~cm}$ of the soil. Together, these results suggest that infauna could translocate $\mathrm{N}$ and $\mathrm{C}$ from the surface to greater depths in the soil profile, and may help explain larger $\mathrm{N}$ and $\mathrm{C}$ pools for the full $20 \mathrm{~cm}$ at some aquaculture sites.

Bioturbation by infauna could also play a role in promoting processes that may reduce the levels of $\mathrm{N}$ and $\mathrm{C}$ within the surface soils. We observed lower accumulations of $\mathrm{N}$ and $\mathrm{C}$ in the upper $5 \mathrm{~cm}$ of the soil, where the majority of infauna were present. The presence of infauna, especially burrowing polychaete worms, could enhance denitrification and mineralization within the surface soils. This is common in marine systems, where bioturbation helps to stimulate remineralization reactions, by introducing oxygen into subsurface sediments, and has been documented to increase 
the decay of organic matter by a factor of ten (Kristensen and Kostka, 2005). Several studies have also shown that bioturbation activity increases denitrification by up to 400\% (Laverock et al., 2011). This is not a direct consequence of macrofaunal bioturbation; rather, it is the result of environmental alterations which affect microbially-driven biogeochemical processes (Laverock et al., 2011). Furthermore, we observed significantly higher abundances of deposit-feeding worms such as polychaetes (Figure 2.9 and 10), which have burrows with microbial communities more similar to those in the oxygenated surface sediment than those in subsurface ambient substrates (Steward et al., 1996). Therefore, increased bioturbation via higher abundances of infauna, more specifically deposit feeding worms, could help explain the lower concentrations of $\mathrm{C}$ and $\mathrm{N}$ found in the surface soils, especially at aquaculture sites.

Aquaculture practices also affected the infaunal communities. We expected to see differences in the diversity of infaunal functional feeding groups between aquaculture and control sites, but there were no significant differences (Figure 2.11). However, we found differences in functional feeding group abundances, where deposit feeder populations were larger at aquaculture sites compared to control sites (Figure 2.9 and 10). A study by Mallet et al. (2006) also found larger populations of deposit feeders at aquaculture sites compared to the control sites, and suggested that the difference could be due to higher levels of aquaculture-derived organic sedimentation or higher organic inputs. C. capitata, an opportunistic polychaete species associated with highly disturbed areas (Mallet et al., 2006), was found throughout both aquaculture and control sites in our study, and aquaculture sites had nearly double the 
abundance of this species (Table 2.3). C. capitata represents a species complex of six sibling species with only minor morphological differences, however, this species complex as whole has been notoriously used as an indicator to assess effects of pollution, particularly within aquaculture areas (Grassle and Grassle, 1976; Dean, 2008). Additionally, Corophium volutator, an opportunistic tube-dwelling amphipod which is commonly found in Europe and northeast North America, made up the majority of the relative abundance of infauna at aquaculture sites and was rarely identified at control sites (Meadows and Reid, 1966, Möller and Rosenberg, 1982, Raffaelli et al., 1991, Flach, 1992). These opportunistic species have life-history traits (e.g. small size, fast growth, high reproductive capacity, and good dispersal ability) that facilitate rapid environmental responses and large increases in abundance in recently disturbed areas. Results suggest that the trophic structure of the infauna shifts to favor deposit-feeding organisms and opportunistic species, as a result of increased inputs of biodeposits and/or disturbances from "off-bottom" aquaculture practices.

Another factor that may contribute to the shift in functional feeding groups is sulfide levels. Although sulfides were present at both aquaculture and control sites, the highest sulfide levels were observed in the top $5 \mathrm{~m}$ of aquaculture sites, especially the 13- and 21-year sites (Figure 2.8). Additionally, our companion study found that pore-water sulfide levels were higher at all aquaculture sites (regardless of duration of aquaculture use), compared to control sites. An early study aimed at evaluating the impact of shellfish culture on the benthic environment observed sulfide levels in the substrate under mussel lines that were 100 times higher than at the reference site within a Swedish inlet (Dahlback and Gunnarsson, 1981). Mattson and Linden (1983) 
conducted a more in-depth study of the benthic macrofauna under mussel-culture, and suggested the high sulfide levels and associated anoxia resulted in transitions toward communities dominated by opportunistic polychaetes, such as C. capitata. Other studies in Canada found lower stocking densities had no negative impact on the benthic community, aside from a partial shift toward anaerobiosis directly under the mussel lines (Hatcher et al., 1994, Grant et al., 1995). These results suggest that the trophic shift observed in our study may be associated with changes in sulfide levels in the soil and soil pore-water.

Although benthic infauna readily respond to local environmental impacts, particularly organic inputs and sulfide levels, they also demonstrate physiological and community changes over time. It is clear from our results that aquaculture facilitated an increase in infaunal abundance between 6 and 12 years of aquaculture use. The infauna identified at all aquaculture sites were predominantly opportunistic species, dominated by burrowing polychaete deposit feeders (Figure 2.10 and Table 2.3). This pattern is indicative of habitat disturbance, which results in dominance by trophic groups that live near the sediment-water interface, a process known as early benthiccommunity succession (Gaston and Nasci, 1988). We should note that there was a decline in the abundance of infauna at sites used for 13 and 21 years of aquaculture use, signaling a shift towards near-initial abundance levels (Figure 2.10). This reversion could be caused by other trophic interactions or environmental responses not measured in this study. For example, Snelgrove et al. (1994) states the processes that influence patterns of community composition and diversity of benthic infauna include those that operate pre- and post-colonization; post-colonization processes include 
abiotic disturbance (Sanders, 1969), predation (Peterson, 1979), and competition (Wilson, 1991). Post-colonization impacts were likely an influence on the 13 and 21years sites, whereby early-colonizing species could have switched feeding modes as they grew accustomed to environmental changes, organisms migrated elsewhere as food became limited, or other predator-prey interactions and competition occurred (Gaston and Nasci, 1988; Snelgrove, 2001; Grabowski, 2004). Additionally, an oyster reef study conducted by Grabowski (2004) acknowledges the influence of predatory epifauna (surface dwelling organisms: fish, crabs, epibenthic macroinvertebrates) on benthic infauna as prey. In a similar estuarine study, Ambrose (1984) found that exclusion of top predators (i.e. epi-benthic macroinvertebrates), resulted in higher abundance of intermediate infaunal predators, suggesting a benefit for infaunal prey (i.e. deposit and interface feeders) within soft-sediment habitats. These trophic interactions could help to explain specific shifts in diversity and abundance for all sites, and especially those trends observed at the 13 and 21 -year sites.

Two of the aquaculture sites we investigated were 6 years old, offering a chance to investigate site specific effects. These two sites showed a different response to aquaculture when compared to the control. The 6(PP) site had significantly higher total C levels, total infauna, number of deposit feeders, and number of interface feeders compared to the control site. In contrast, site 6(WP) only had a significantly lower total C levels, and higher number of deposit feeders than control sites. Because these same-aged sites have few measurable impacts in common, we acknowledge that site-specific factors are important to consider. Site-specific maintenance protocols, in particular, likely disrupt the effects caused by continued durations of aquaculture use. 
Because racks are routinely moved and relocated during maintenance, it is apparent that no site received biodeposit inputs to the exact same location for the full duration of aquaculture use. As such, results suggest that regardless of duration of aquaculture use or site-specific factors, aquaculture practices mainly affected the trophic structure of infaunal communities, causing a shift towards opportunistic-dominated infauna.

\section{CONCLUSIONS}

The effects of oyster biodeposits and aquaculture practices to the soils and infauna are an important consideration for determining short- and long-term environmental impacts. Our results show that oysters produce biodeposits with $\mathrm{N}$ and C levels two orders of magnitude higher than the levels which naturally occur in the soil, thus biodeposits produce organic loads capable of enriching the benthic environment under aquaculture racks. Biodeposition rates were influenced by oyster size and stocking density, whereby larger oysters and higher stocking densities produce greater amounts of biodeposits. Based on our oyster density experiment, we found there was no difference in the concentration of $\mathrm{N}$ and $\mathrm{C}$ in the soil, after one week of biodeposit enrichment, across control (no oysters), average, and high stocking densities (of near market sized oysters, $6 \mathrm{~cm}$ ). These results suggest oyster biodeposition has limited short-term impact on surface soil, even at high oyster stocking densities. Sandy soils may have high rates of $\mathrm{N}$ and $\mathrm{C}$ removal and infaunal activity which help to process the $\mathrm{N}$ and $\mathrm{C}$ in biodeposits, both out of the soil and/or deeper into the soil profile. 
Although there was no short-term impact from oyster biodeposits, we identified several impacts from oyster aquaculture to the soils and infauna over a range of continued aquaculture use (0-21 years). Our results show significant differences in soil bulk density, total $\mathrm{N}$, total $\mathrm{C}$, and $\Delta \mathrm{pH}$ among sites, however, these differences were not directly proportional with age of aquaculture use. Bulk density varied with depth across all sites, while low surface bulk density $(<1.2 \mathrm{~g} \mathrm{~cm} \mathrm{-3)} \mathrm{was} \mathrm{observed} \mathrm{at}$ multiple aquaculture sites. Higher levels of total $\mathrm{N}$ and $\mathrm{C}$ were found deeper in the soil profile across the majority of sites, with the highest $\mathrm{C}$ and $\mathrm{N}$ pools at the 12-year aquaculture site. Additionally, $\Delta \mathrm{pH}$ (a proxy for soil sulfide concentration) varied among age sites and was not significantly different as a function of depth, although pore-water sulfide data show higher levels of sulfides at aquaculture sites, particularly within the upper $10 \mathrm{~cm}$. Analysis of benthic infauna show that higher abundance of infauna, deposit-feeders, and interface-feeders were found at aquaculture sites, compared to control sites. Infaunal abundance was also not directly proportional to age of aquaculture use, nor significantly correlated with bulk density, $\mathrm{N}$ and $\mathrm{C}$ pools, or $\Delta \mathrm{pH}$ of the soils. Although we saw few significant differences in infaunal abundance, higher numbers of opportunistic species indicative of disturbance - such as C. capitata and C. volutator - were found at aquaculture sites compared to control sites. Our results suggest soil properties and infauna changed as a result of aquaculture at some sites; however, because aquaculture racks are routinely rotated and relocated during maintenance, this may explain why we see a lack of effects from biodepositional inputs on the soil properties over long-term durations of aquaculture use. These data lead us to believe physical disturbances as well as oyster biodeposits 
from aquaculture practices could alter the chemical and physical properties of the soil, causing an increase in the abundance of infauna, as well as a negative shift in the trophic community structure of infauna. 


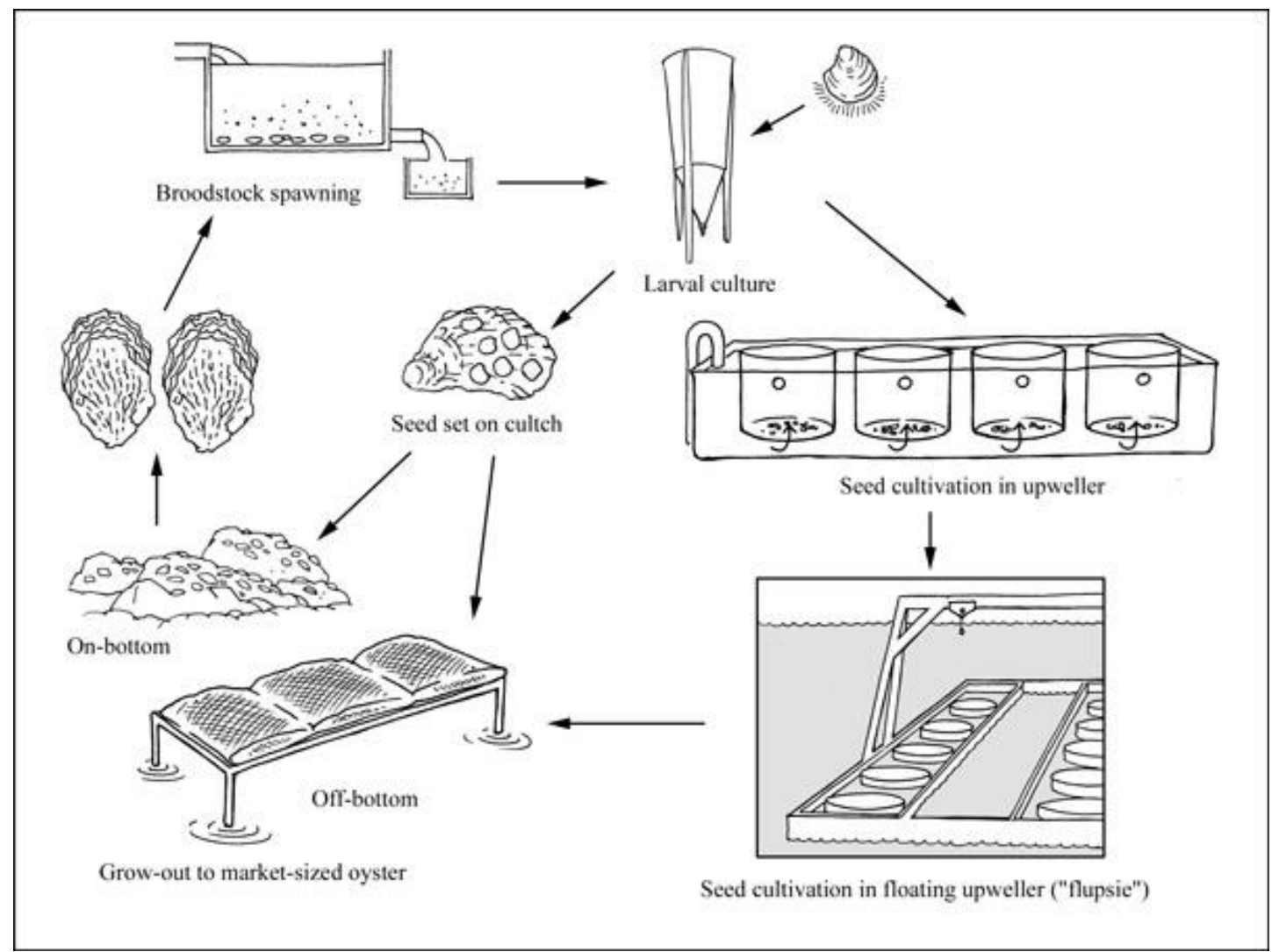

Figure 2.1 Oyster aqauculture growing techniques and apparatuses. Upweller apparatus is utilized for nursing seed to juvenile sized oysters. Grow-out (on- and offbottom) techniques are utilized for juvenile to adult oysters.

(Source: http://www.fao.org/fishery/culturedspecies/Crassostrea_virginica/en) 


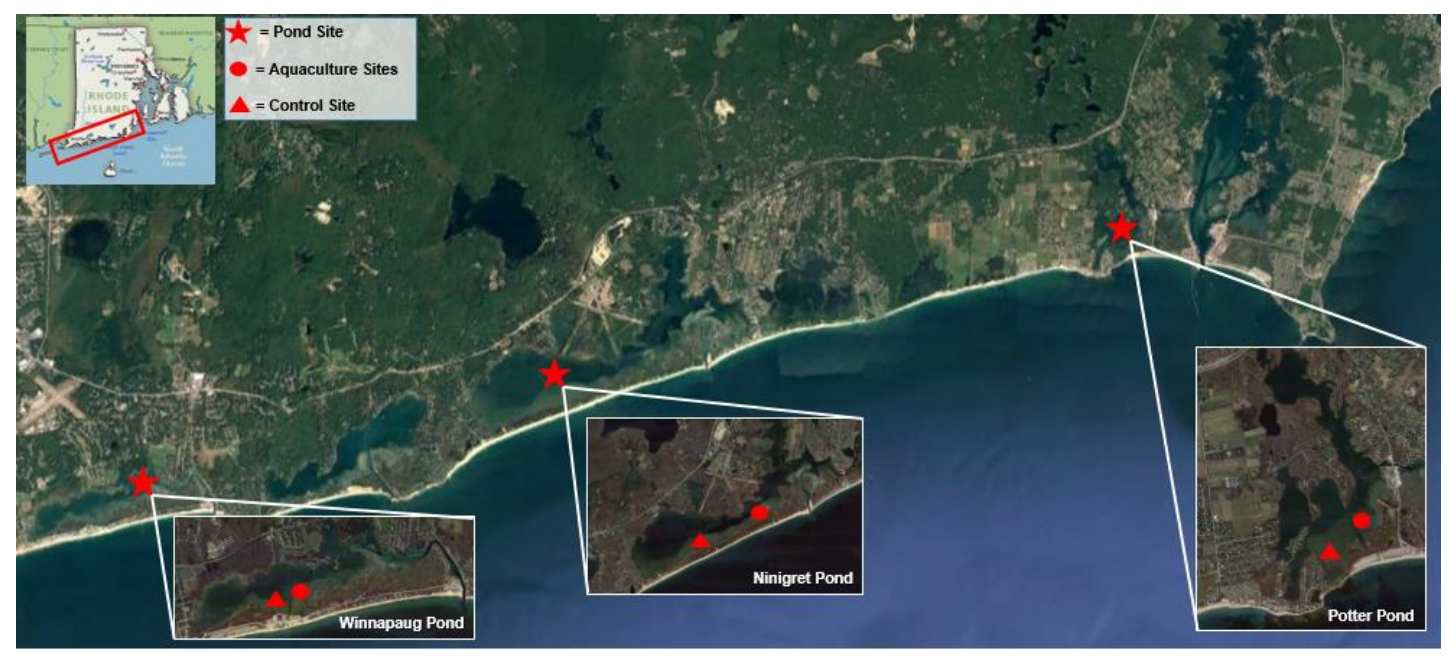

Figure 2.2 Map of study sites in southern Rhode Island. Inset maps show soil sampling locations in Winnapaug Pond (WP), Ninigret Pond (NP), and Potter Pond (PP). We sampled soil and benthic cores at all aquaculture and control sites. The control site in NP was also used for the fertilization experiment. 


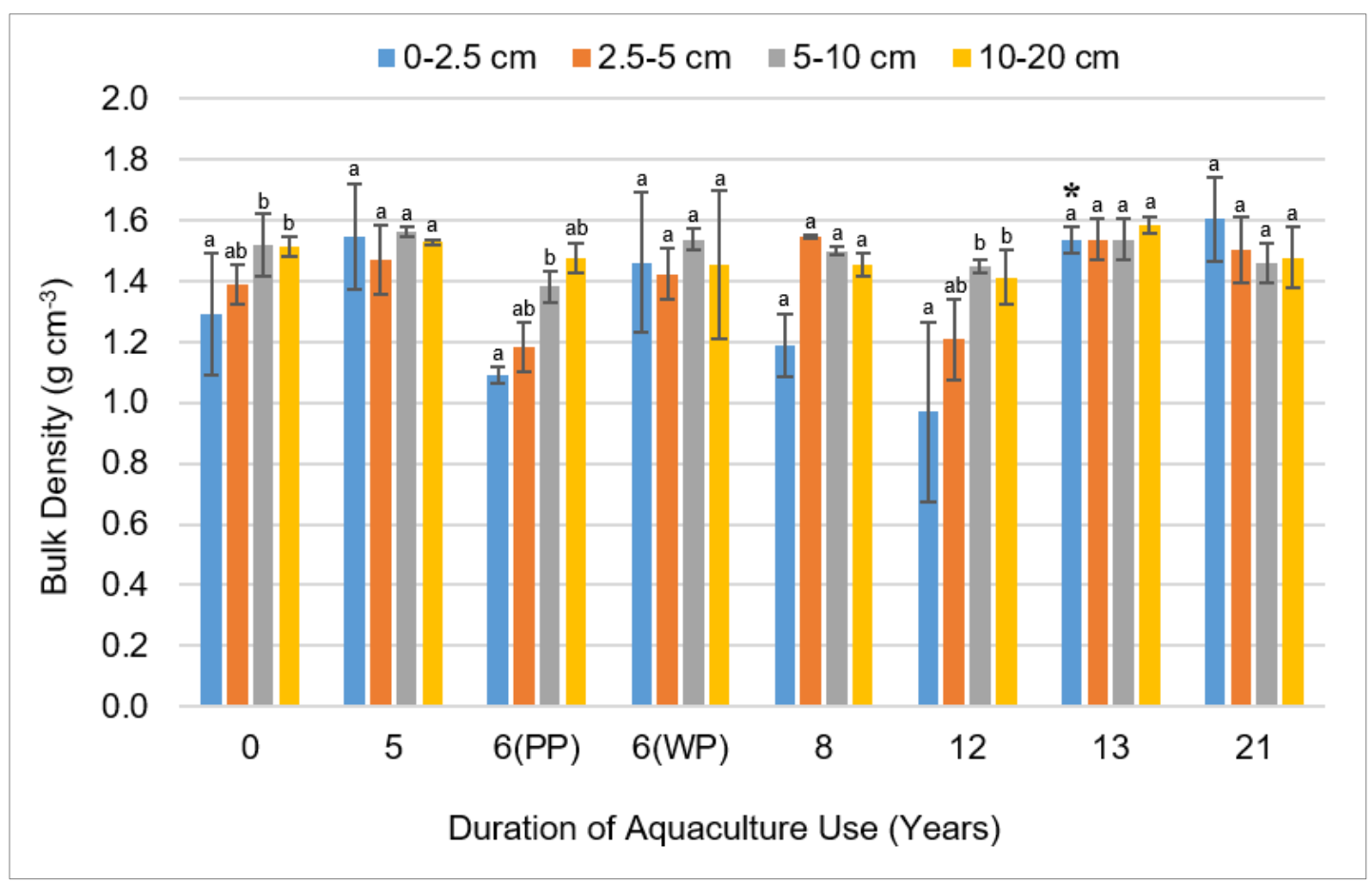

Figure 2.3 Mean $(n=3)$ bulk density at different soil depths as a function of years in aquaculture. Error bars represent one standard deviation from the mean. Significant differences from the control site (0 years) are indicated with an asterisk (*). Significant differences between depth increments at each age site are indicated by letters. 


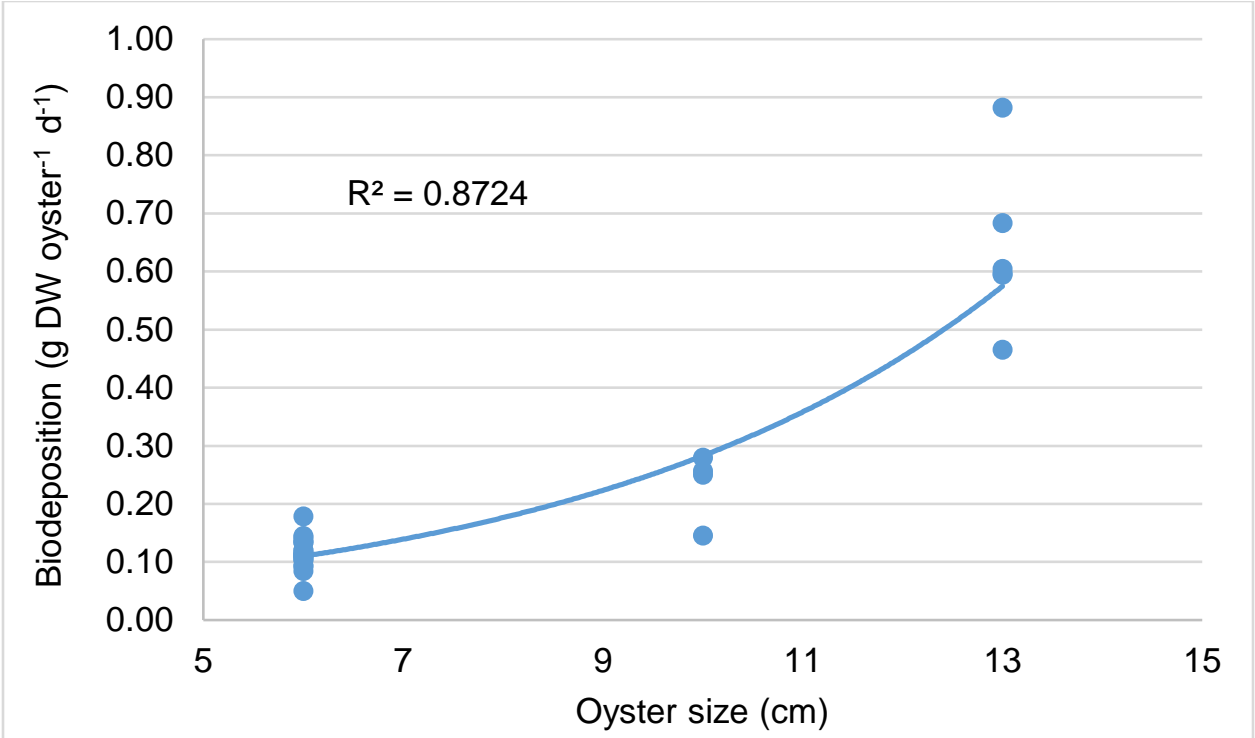

Figure 2.4 The relationship between oyster size $(\mathrm{cm})$ and biodepostion rate $(\mathrm{g}$ DW oyster $\left.{ }^{-1} \mathrm{~d}^{-1}\right)$. 


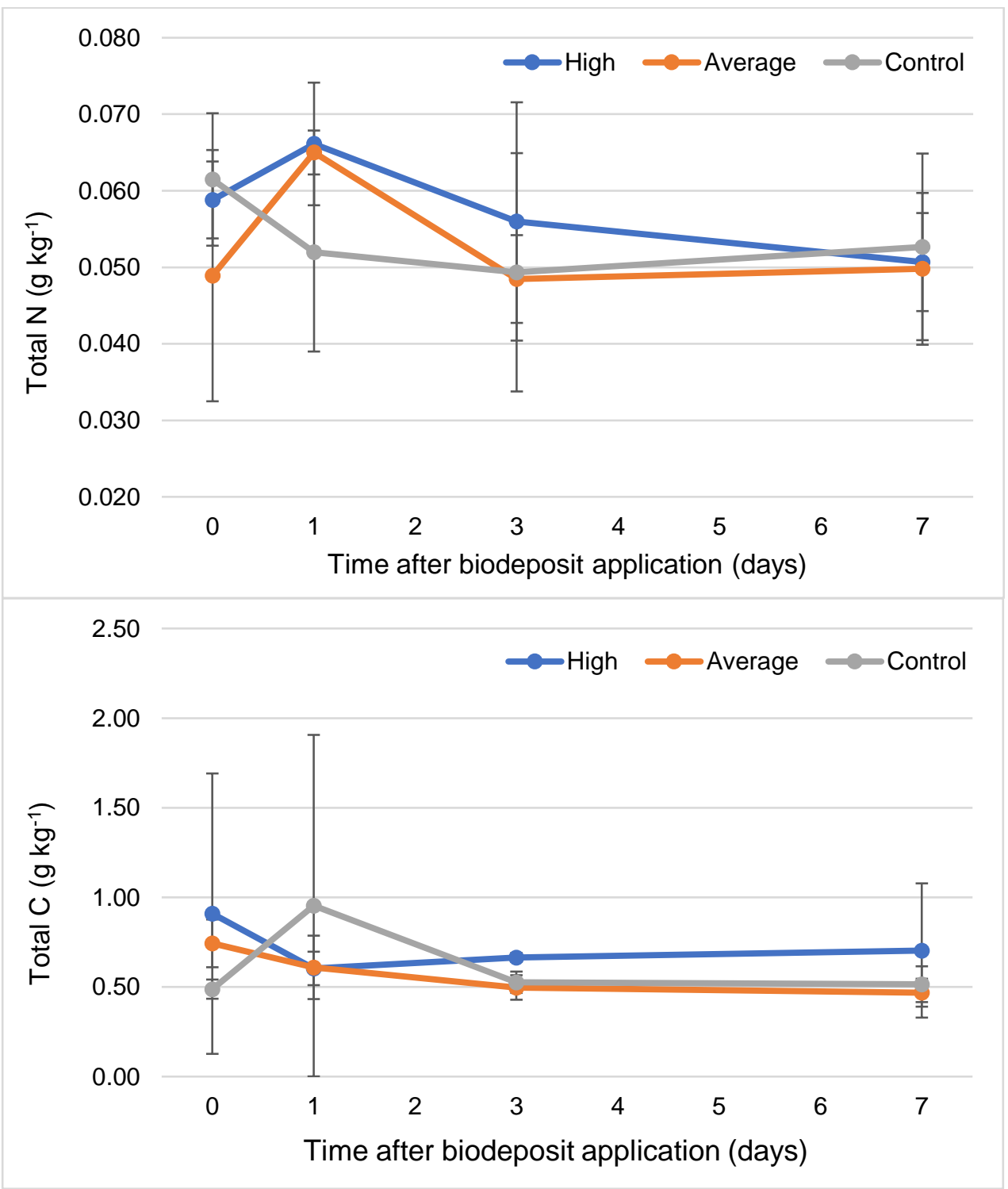

Figure 2.5 Mean total $\mathrm{N}$ and $\mathrm{C}$ levels in the soil as a function of time after application of biodeposits. Error bars represent one standard deviation from the mean. Soils were sampled from the upper $2 \mathrm{~cm}$ of the soil profile at $0,1,3.5$ and 7 days after biodeposits were applied to the soil surface. 


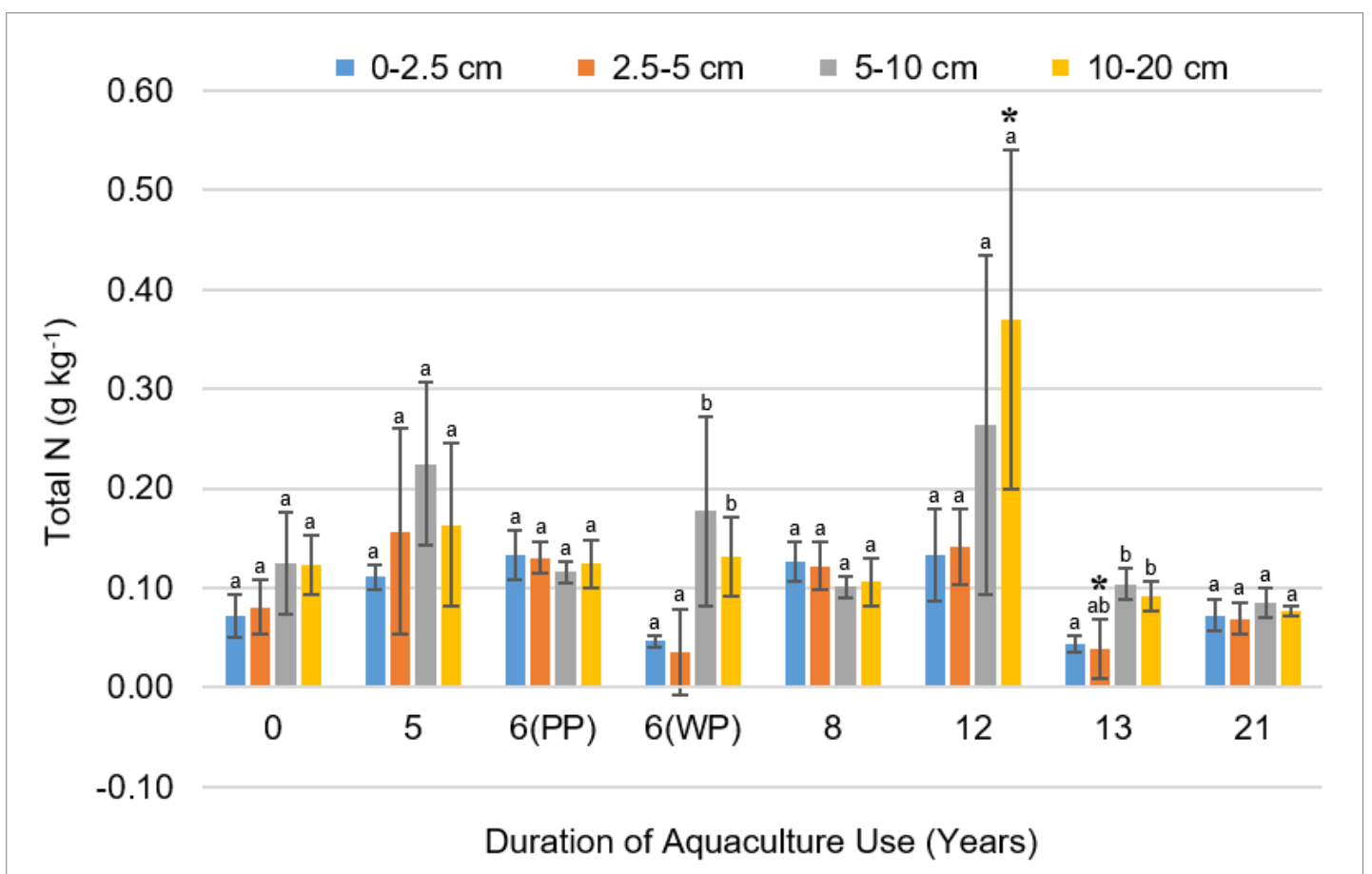

Figure 2.6 Mean $(n=3)$ levels of total $\mathrm{N}$ at different soil depths as a function of years in aquaculture. Error bars represent one standard deviation from the mean. Significant differences from the control site (0 years) are indicated with an asterisk (*).

Significant differences between depth increments at each age site are indicated by letters. 


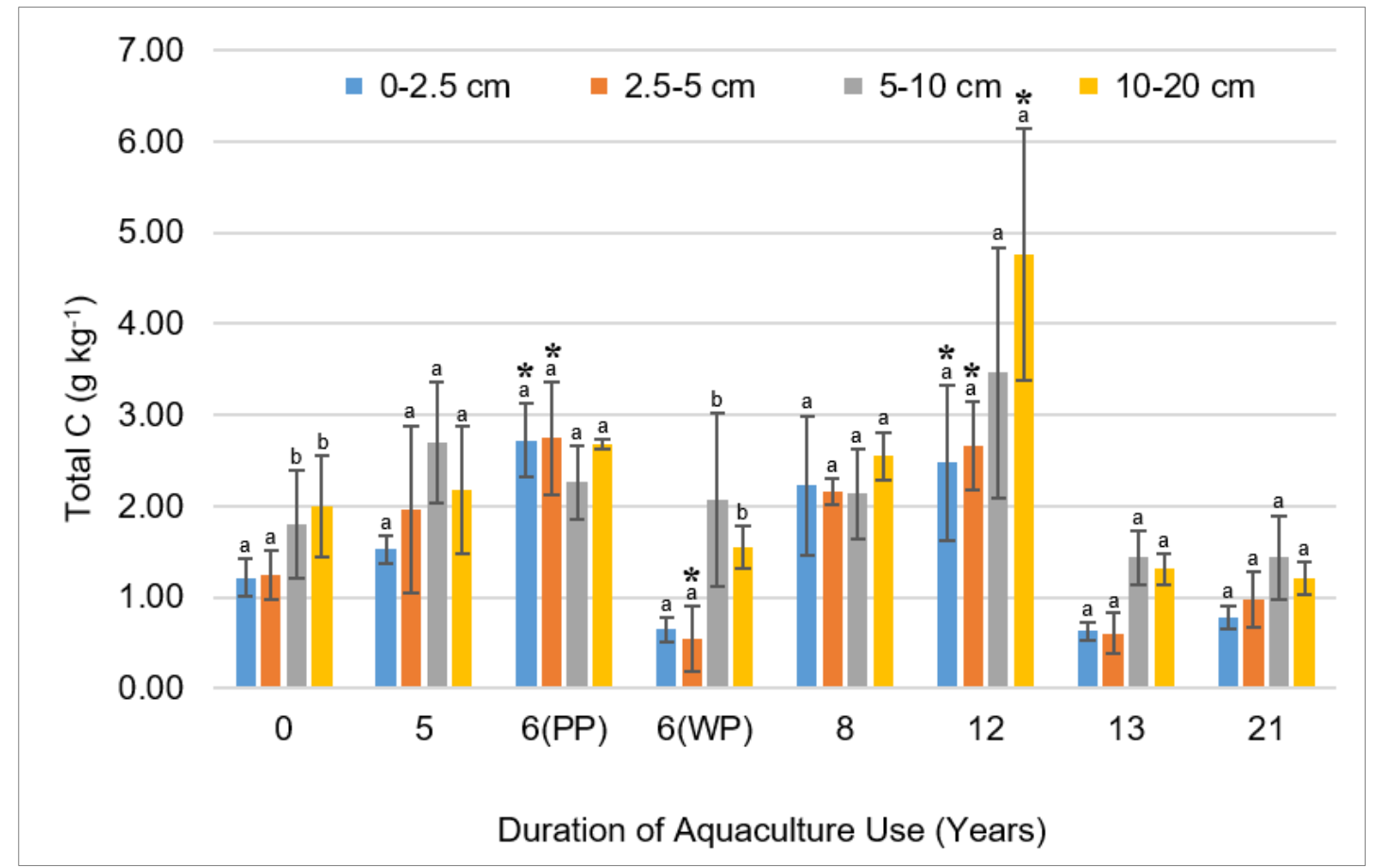

Figure 2.7 Mean $(n=3)$ levels of total $\mathrm{C}$ at different soil depths as a function of years in aquaculture. Error bars represent one standard deviation from the mean. Significant differences from the control site (0 years) are indicated with an asterisk (*).

Significant differences between depth increments at each age site are indicated by letters. 


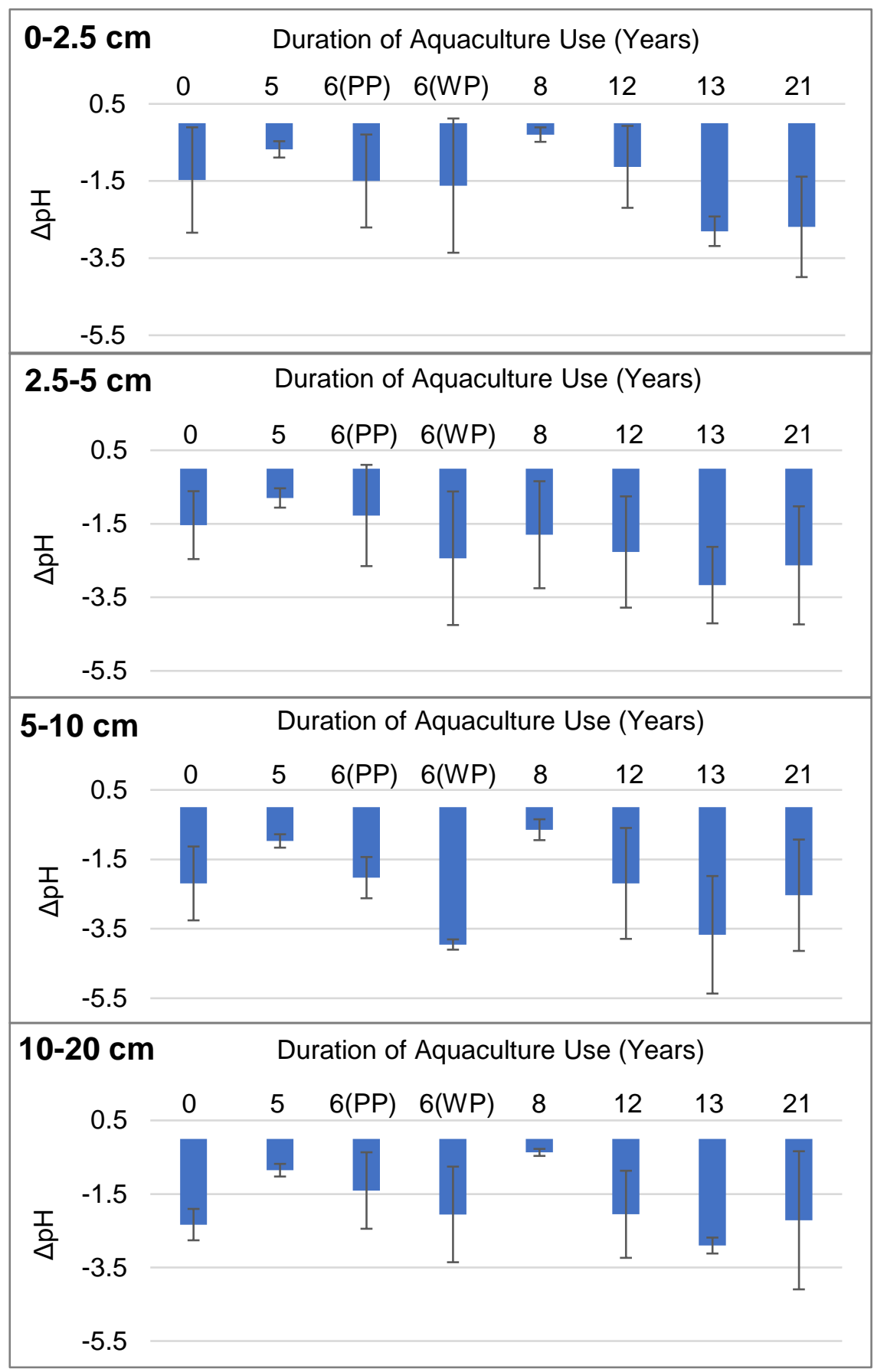

Figure 2.8 Mean $(\mathrm{n}=3) \Delta \mathrm{pH}$ at different soil depths as a function of years in aquaculture. Error bars represent one standard deviation from the mean. Significant differences from the control site (0 years) are indicated with an asterisk (*). Greater changes in $\mathrm{pH}$ were equated to higher soil sulfide levels. This assumed equal buffering capacity and acid neutralization in all the soils. 


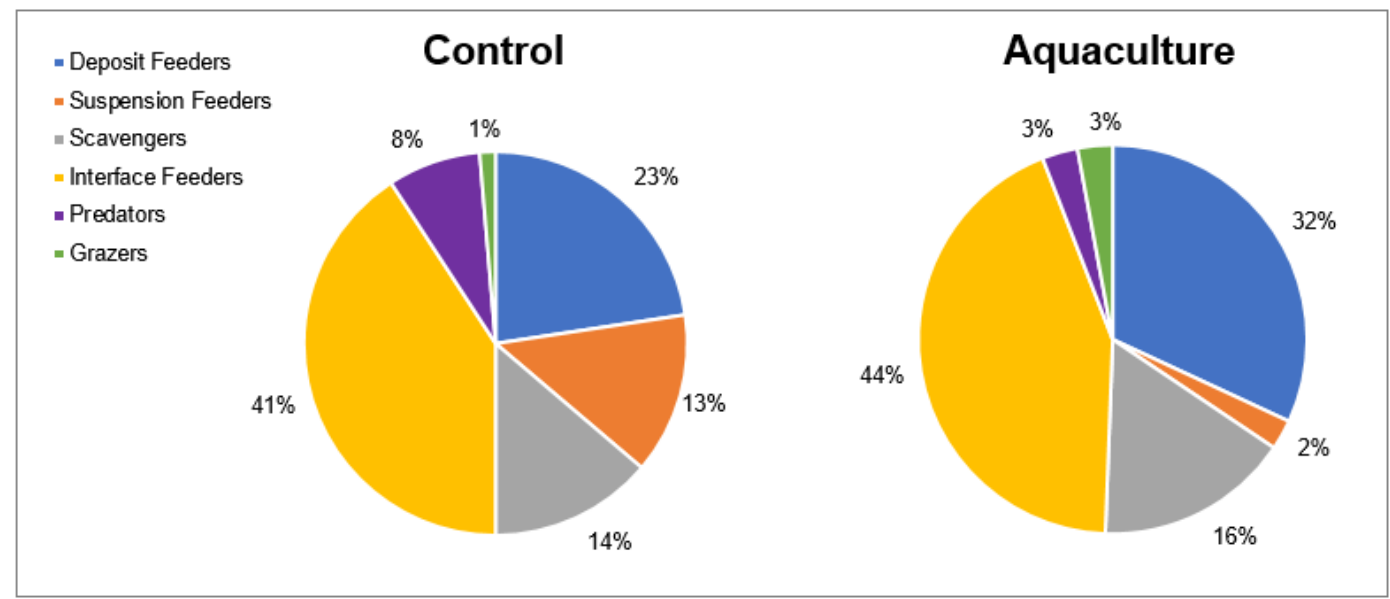

Figure 2.9 Relative distribution of functional feeding group for total mean abundance of infauna in aquaculture and control sites. 


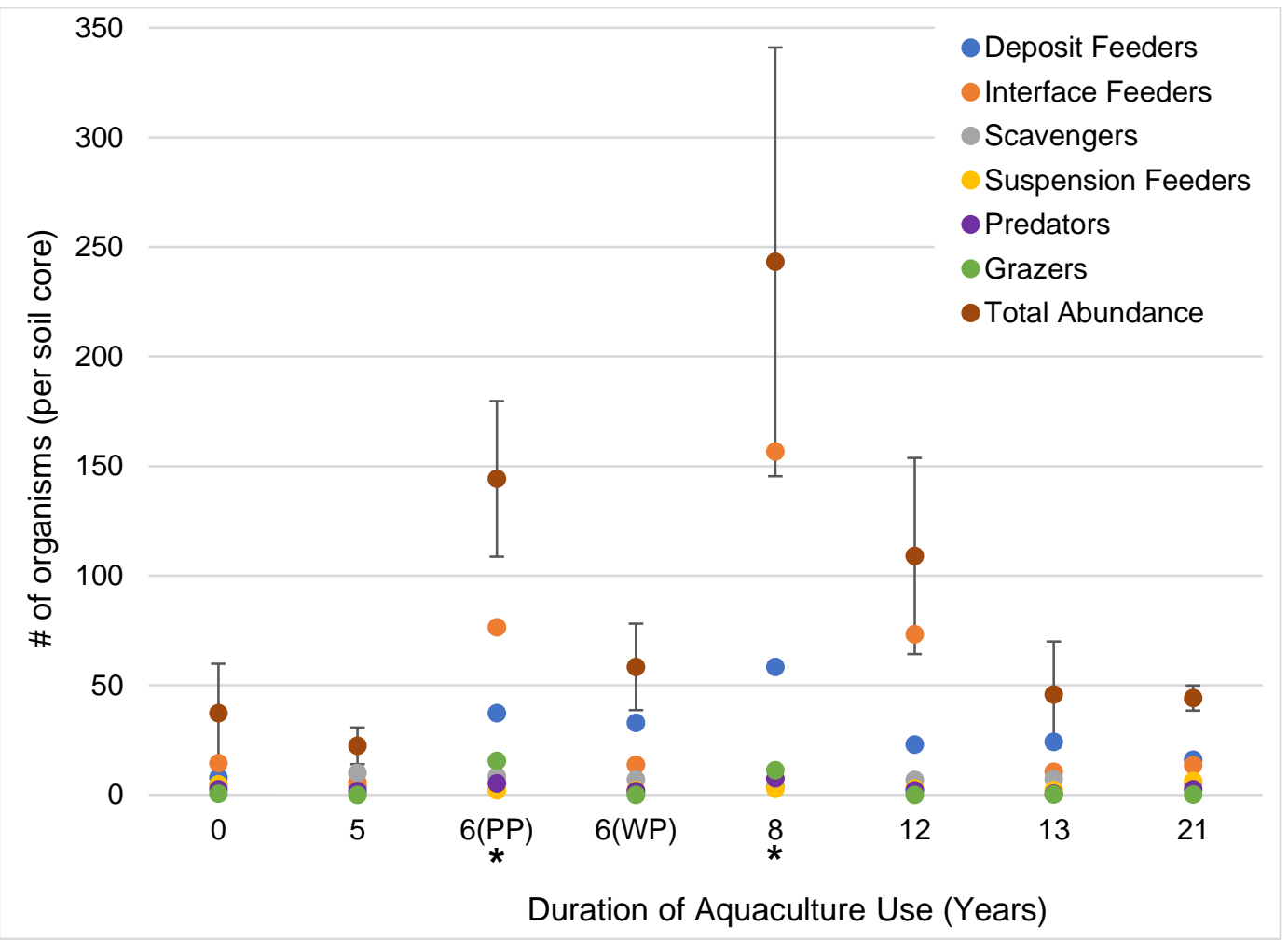

Figure 2.10 Mean $(n=5)$ abundance of infauna and functional feeding groups as a function of years in aquaculture. Each mean represents average number of infauna from a $1570 \mathrm{~cm}^{3}$ soil core. Error bars represent one standard deviation from the mean. Significant differences from the control site (0 years) are indicated with an asterisk $(*)$. 


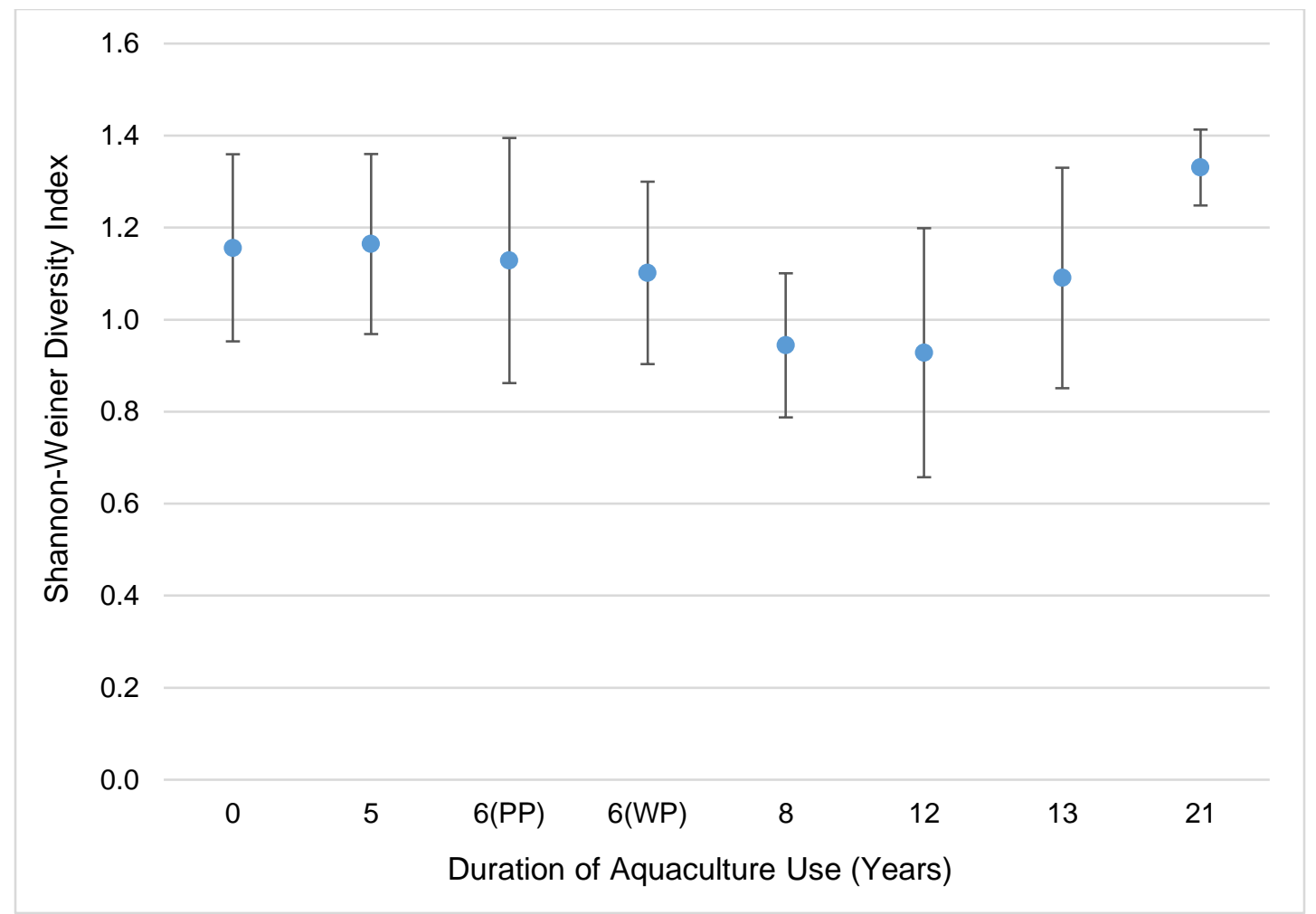

Figure 2.11 Mean $(n=5)$ diversity of infaunal functional feeding groups as a function of years in aquaculture. Each mean represents calculated Shannon-Wiener Diversity index values among infauna collected in a $1570 \mathrm{~cm}^{3}$ soil core. Error bars represent one standard deviation from the mean. 


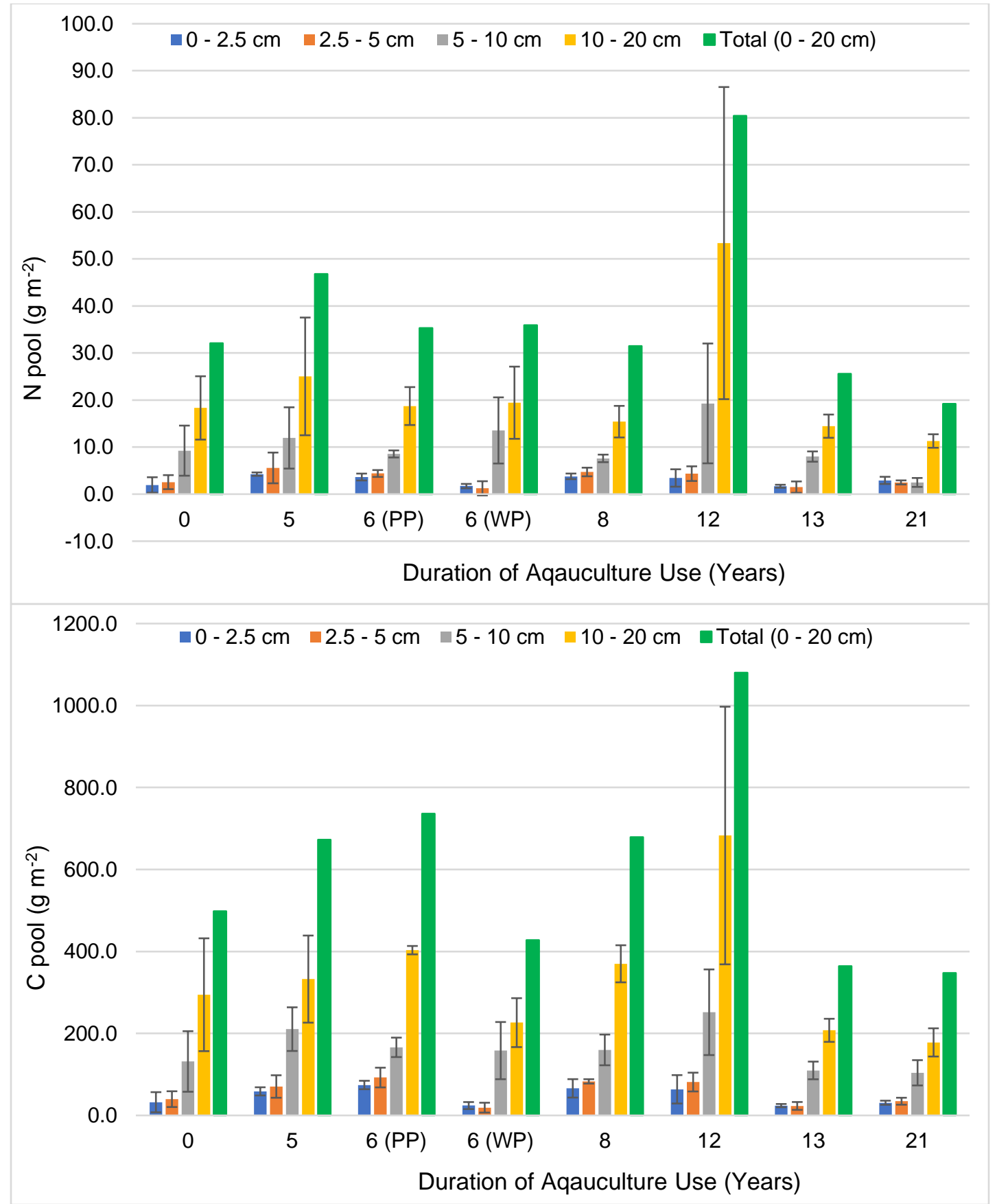

Figure 2.12 Calculated mean $(n=3) \mathrm{N}$ and $\mathrm{C}$ pools at different depth ranges. $\mathrm{N}$ and $\mathrm{C}$ pools represent the function of bulk density and total $\mathrm{N}$ or $\mathrm{C}$ concentrations, per age site. Error bars represent one standard deviation from the mean. The green bar represents the mean total $\mathrm{N}$ or $\mathrm{C}$ pool for each site. 
Table 2.1 Comparison of previously published oyster biodeposition rates with those in our study.

\begin{tabular}{|c|c|c|c|c|c|c|}
\hline Location & Species & $\begin{array}{l}\text { Size of } \\
\text { Oyster } \\
\text { (cm) }\end{array}$ & $\begin{array}{c}\text { Density } \\
\left(\mathbf{m}^{-2}\right)\end{array}$ & $\begin{array}{l}\text { Biodeposition } \\
\left(\mathrm{g} \mathrm{DW} \mathrm{m}^{-2} \mathrm{~d}^{-1}\right)\end{array}$ & $\begin{array}{c}\text { Biodeposition } \\
\left(\text { g DW oys }^{-1} \text { day }^{-1}\right)\end{array}$ & Source \\
\hline $\begin{array}{l}\text { York River, } \\
\text { USA }\end{array}$ & $\overline{\mathrm{CV}}$ & - & 62 & $14.3-34.6$ & $0.23-0.56$ & $\begin{array}{c}\text { Haven } \\
\text { and } \\
\text { Morales- } \\
\text { Alamo } \\
\text { (1966) }\end{array}$ \\
\hline $\begin{array}{l}\text { Hiroshima } \\
\text { Bay, Japan }\end{array}$ & $\mathrm{Cg}$ & - & 2117 & $3-277$ & $0.042-0.288$ & $\begin{array}{c}\text { Arakawa } \\
\text { et al. } \\
\text { (1971) }\end{array}$ \\
\hline $\begin{array}{l}\text { British } \\
\text { Columbia, } \\
\text { Canada }\end{array}$ & $\mathrm{Cg}$ & - & - & 5.7 & $0.12-0.22$ & $\begin{array}{c}\text { Bernard } \\
\text { (1974) }\end{array}$ \\
\hline $\begin{array}{l}\text { Marennes- } \\
\text { Oléron, } \\
\text { France }\end{array}$ & $\mathrm{Cg}$ & - & 200 & $480-6000$ & $2.4-30$ & $\begin{array}{l}\text { Sormin } \\
\text { et al. } \\
(1983)\end{array}$ \\
\hline $\begin{array}{l}\text { Tasmania, } \\
\text { Australia }\end{array}$ & $\mathrm{Cg}$ & $6-7$ & 360 & $39.6-180.5$ & $0.064-0.29$ & $\begin{array}{l}\text { Mitchell } \\
\text { (2006) }\end{array}$ \\
\hline $\begin{array}{c}\text { Ninigret } \\
\text { Pond, Rhode } \\
\text { Island, USA }\end{array}$ & $\mathrm{Cv}$ & 6 & 670 & $68.8-82.3^{*}$ & $0.10-0.12 *$ & $\begin{array}{c}\text { Duball et } \\
\text { al. } \\
\text { (this } \\
\text { study) }\end{array}$ \\
\hline $\begin{array}{l}\text { Potter Pond, } \\
\text { Rhode Island, } \\
\text { USA }\end{array}$ & $\mathrm{Cv}$ & 6 & 560 & $67.8-72.6^{*}$ & $0.12-0.13^{*}$ & $\begin{array}{c}\text { Duball et } \\
\text { al. } \\
\text { (this } \\
\text { study) }\end{array}$ \\
\hline $\begin{array}{l}\text { Winnapaug } \\
\text { Pond, Rhode }\end{array}$ & $\mathrm{Cv}$ & 10 & 870 & 202.33 & 0.23 & $\begin{array}{c}\text { Duball et } \\
\text { al. }\end{array}$ \\
\hline Island, USA & & 13 & 540 & 346.47 & 0.64 & $\begin{array}{c}\text { (this } \\
\text { study) }\end{array}$ \\
\hline
\end{tabular}


Table 2.2 Functional feeding group identification key and ecological descriptions.

\begin{tabular}{|c|c|}
\hline Functional feeding group & Description \\
\hline Deposit & Feed on organic matter (detritus) in substrate \\
\hline Suspension/Filter & Filter particles out of water column \\
\hline Scavenger/Collector & $\begin{array}{l}\text { Search through sediments to feed on dead organisms (not } \\
\text { active hunters) }\end{array}$ \\
\hline Interface & Alternate between deposit/ suspension feeding \\
\hline Predator & Capture and consume live prey \\
\hline Grazers/Scrapers & Scrape plant material from various substrates \\
\hline Parasite & $\begin{array}{l}\text { Odostomia sp. and Prunum roscidum only. These snails } \\
\text { use their radula to bore into other organisms and ingest } \\
\text { their tissues. }\end{array}$ \\
\hline
\end{tabular}


Table 2.3 Comparison of the top five species identified at control and aquaculture sites.

\begin{tabular}{|c|c|c|c|c|}
\hline Species & Class & $\begin{array}{c}\text { Functional Feeding } \\
\text { Group }\end{array}$ & \multicolumn{2}{|c|}{$\begin{array}{c}\text { Relative } \\
\text { Abundance (\%) }\end{array}$} \\
\hline \multicolumn{5}{|c|}{ CONTROL } \\
\hline Prionospio dubia & Polychaeta & Interface & 31 & \\
\hline Gemma gemma & Bivalvia & Suspension & 11 & \\
\hline Alitta succinea & Polychaeta & Scavenger & 10 & \\
\hline Capitella capitata & Polychaeta & Deposit & 8 & \\
\hline \multirow[t]{2}{*}{ Dipolydora commensalis } & Polychaeta & Interface & 7 & \\
\hline & & & TOTAL: & 67 \\
\hline \multicolumn{5}{|c|}{ AQUACULTURE } \\
\hline Corophium volutator & Malacostraca & Interface & 27 & \\
\hline Capitella capitata & Polychaeta & Deposit & 16 & \\
\hline Prionospio dubia & Polychaeta & Interface & 12 & \\
\hline Stenopleustes inermis & Malacostraca & Deposit, scavenger & 11 & \\
\hline \multirow[t]{2}{*}{ Dipolydora commensalis } & Polychaeta & Interface & 7 & \\
\hline & & & TOTAL: & 74 \\
\hline
\end{tabular}




\section{CONCLUSIONS}

Oyster aquaculture impacts the environment through filter-feeding, biodeposition, and physical disturbances that are part of aquaculture practices. This study set out to examine the magnitude of these effects on the benthic environment and overlying water column and to determine whether the amount of time that a site has been in aquaculture has an effect. Measurements of biodeposition rates suggested that a $1-\mathrm{m}^{-2}$ rack of oysters removed about 1 to $2 \mathrm{~g}$ of $\mathrm{N}$ per day from the water column. These reductions in $\mathrm{N}$ concentration were not evident in the water quality measures, as there were no significant differences in either ammonium or nitrate levels between control and aquaculture sites. Likewise, water column DO and TSS were similar between the aquaculture and control sites. We did find that there was significantly lower chl $a$ levels between aquaculture and control sites, and the lowest chl $a$ levels were recorded at aquaculture sites in the summer and fall months when water temperatures were warmest and oysters were most active. One apparent negative impact of biodeposits was an increase in hydrogen sulfide levels in the pore water below the aquaculture sites.

To examine the impacts of oyster aquaculture to the benthic environment, we conducted a three-part study to investigate the impacts of biodeposits and aquaculture practices on the soil properties and resident infauna. We first measured rates of biodeposits relative to oyster size and density. We found that larger oysters and higher stocking densities produce greater amounts of biodeposits. We then tested how the soil would react if we increased oyster density by applying a one week's worth of

biodeposits to the soil from oyster densities of 500 and 2000 oysters $\mathrm{m}^{-2}$. At no time 
during the week-long experiment $(1,3.5$, or 7 days after application) did we detect significantly higher $\mathrm{N}$ or $\mathrm{C}$ levels in the treated soils relative to the initial levels (day 0 ), or to the control. Understanding the mechanisms for removal of $\mathrm{C}$ and $\mathrm{N}$ were beyond the scope of this study, however, possible explanations include infaunal translocation of biodeposits below the upper $2 \mathrm{~cm}$ of the soil we sampled and/or rapid denitrification.

Finally, we investigated the impacts of oyster aquaculture to the soil and resident infauna over longer durations of aquaculture use. We found significant differences in bulk density, total $\mathrm{N}$, total $\mathrm{C}$, and soil sulfide levels (change in incubation $\mathrm{pH}$ ) across sites ( 0 to 21 years of aquaculture use). There were also significant differences in soil properties between some aquaculture age sites and the control site, but differences at aquaculture sites were not consistently higher or lower than control sites, nor were they directly related to the duration of aquaculture use. Although soil $\mathrm{N}$ and $\mathrm{C}$ levels varied between age sites, levels were typically lower in the surface soils $(0-5 \mathrm{~cm})$ and higher at the greater soil depths $(5-20 \mathrm{~cm})$ across the majority of sites. Although soil sulfide levels varied across site age and depth, porewater sulfide evidence from an accompanying study shows that all aquaculture sites had higher levels of sulfides than control sites. These patterns suggest differences in soil properties among sites are likely influenced by site specific impacts (e.g. stocking density, position within the water column, maintenance protocols, and harvest techniques), as opposed to the years of aquaculture use.

Total abundance of infauna, and of deposit feeders, interface feeders, and parasites were significantly higher at aquaculture sites compared to control sites. 
Although functional diversity of infauna was not significantly different among sites, the 8 and 12-year aquaculture sites had both the highest abundance of infauna and the lowest diversity. There was also nearly double the relative abundance of Capitella capitata, an opportunistic polychaete species indicative of disturbance, at aquaculture sites compared to control sites, and the majority of infauna found at aquaculture sites was accounted for by Corophium volutator, another opportunistic species associated with high levels of disturbance. These data suggest some aquaculture sites experience a trophic shift among their infaunal communities - compared to control sites - favoring lower-order deposit and interface feeders, with a greater presence of opportunistic species.

Cultured-oysters appeared to affect chl $a$ levels, helping to improve water clarity and reduce effects of anoxia caused by eutrophication; however, we see some negative impacts on the soil properties (increased sulfide levels) and infauna (lower trophic community structure). Biodeposits did not result in $\mathrm{N}$ and $\mathrm{C}$ enrichment to the soil over short term applications and had minimal impact over longer-periods of aquaculture use (5-21 years). Because total infaunal abundance was not significantly correlated with bulk density, total $\mathrm{C}$ and $\mathrm{N}$, or soil sulfide levels, this suggests other processes such as physical disturbances may have a greater effect on the benthic environment. Aquaculture racks are routinely rotated and relocated during maintenance, which may explain why we see a lack of effects from biodepositional inputs on the soil properties over long-term durations of aquaculture use. Maintenance and movement of heavy racks and foot-traffic from aquaculture farmers also increase soil disturbances, which could negatively alter the composition and ecology of the 
surface soils and resident infauna. These disturbances are likely select for higher populations of deposit feeders and opportunistic species (indicative of disturbance) at all aquaculture sites $>5$ years old. Although we saw a shift in trophic quality in response to oyster biodeposition and disturbance, the combination of these impacts may also aid in improving $\mathrm{N}$ and $\mathrm{C}$ sequestration deeper in the soil profile via soil compaction, and increased infaunal translocation of biodeposit inputs.

Effective management of coastal resources need to consider the processes of aquaculture (i.e. filtration and biodeposition of oysters) and the physical practices (i.e. rack maintenance, foot-traffic, boat anchoring), when assessing the environmental impacts of aquaculture. Our results provide useful baseline data and a basis for monitoring to identify specific environmental impacts associated with oyster aquaculture. Aquaculture farmers may find our data useful to determine and monitor site suitability factors such as water and soil quality, and to decide which what type of gear will have the lowest environmental impact (i.e. floating gear vs. rack and bag culture). Our results suggest oyster aquaculture is environmentally sustainable at greater stocking densities and longer periods of aquaculture use, with only minor concerns in regard to the trophic structure of benthic infaunal communities. 


\section{APPENDICES}

Appendix 1. Soil properties across depth at all sites

\begin{tabular}{|c|c|c|c|c|c|c|c|c|c|}
\hline $\begin{array}{c}\text { Duration of } \\
\text { aquaculture } \\
\text { use } \\
\text { (years) }\end{array}$ & $\begin{array}{c}\text { Depth } \\
\text { (cm) }\end{array}$ & $\begin{array}{c}\% \\
\text { Silt } \\
\text { and } \\
\text { Clay }\end{array}$ & $\begin{array}{c}\% \\
\text { VCO }\end{array}$ & $\begin{array}{c}\% \\
\text { CO }\end{array}$ & $\begin{array}{l}\% \% \\
M\end{array}$ & $\begin{array}{l}\% \\
\text { F }\end{array}$ & $\begin{array}{l}\% \\
\text { VF }\end{array}$ & $\begin{array}{c}\text { BD } \\
\left(\mathrm{g} \mathrm{cm}^{-3}\right)\end{array}$ & $\begin{array}{c}\mathbf{E C} \\
\left(\mathrm{mS} \mathrm{m}^{-1}\right)\end{array}$ \\
\hline \multirow[t]{4}{*}{0} & $0-2.5$ & 4 & 1 & 9 & 34 & 46 & 7 & 1.29 & 2.13 \\
\hline & $2.5-5$ & 5 & 1 & 8 & 33 & 46 & 6 & 1.39 & 2.30 \\
\hline & $5-10$ & & & & & & & 1.52 & 2.24 \\
\hline & $10-20$ & & & & & & & 1.51 & 2.00 \\
\hline \multirow[t]{4}{*}{5} & $0-2.5$ & 3 & 1 & 8 & 31 & 50 & 6 & 1.55 & 2.48 \\
\hline & $2.5-5$ & 4 & 1 & 8 & 30 & 51 & 7 & 1.47 & 2.40 \\
\hline & $5-10$ & & & & & & & 1.56 & 2.69 \\
\hline & $10-20$ & & & & & & & 1.53 & 2.54 \\
\hline \multirow[t]{4}{*}{$6(\mathrm{PP})^{*}$} & $0-2.5$ & 7 & 1 & 1 & 23 & 62 & 5 & 1.09 & 2.61 \\
\hline & $2.5-5$ & 5 & 0 & 0 & 25 & 63 & 4 & 1.18 & 2.40 \\
\hline & $5-10$ & & & & & & & 1.38 & 2.23 \\
\hline & $10-20$ & & & & & & & 1.48 & 1.87 \\
\hline \multirow[t]{4}{*}{$6(\mathrm{WP})^{*}$} & $0-2.5$ & 4 & 0 & 2 & 29 & 63 & 2 & 1.46 & 2.66 \\
\hline & $2.5-5$ & 5 & 0 & 2 & 29 & 62 & 2 & 1.42 & 2.32 \\
\hline & $5-10$ & & & & & & & 1.54 & 2.74 \\
\hline & $10-20$ & & & & & & & 1.45 & 2.05 \\
\hline \multirow[t]{4}{*}{8} & $0-2.5$ & 4 & 1 & 1 & 28 & 61 & 4 & 1.19 & 2.68 \\
\hline & $2.5-5$ & 6 & 0 & 0 & 27 & 59 & 4 & 1.55 & 2.36 \\
\hline & $5-10$ & & & & & & & 1.50 & 2.17 \\
\hline & $10-20$ & & & & & & & 1.45 & 2.14 \\
\hline \multirow[t]{4}{*}{12} & $0-2.5$ & 7 & 1 & 1 & 26 & 60 & 4 & 0.97 & 2.88 \\
\hline & $2.5-5$ & 6 & 0 & 0 & 26 & 61 & 4 & 1.21 & 2.42 \\
\hline & $5-10$ & & & & & & & 1.45 & 2.30 \\
\hline & $10-20$ & & & & & & & 1.41 & 2.36 \\
\hline \multirow[t]{4}{*}{13} & $0-2.5$ & 6 & 0 & 3 & 30 & 58 & 3 & 1.53 & 2.61 \\
\hline & $2.5-5$ & 4 & 0 & 2 & 29 & 61 & 3 & 1.54 & 2.44 \\
\hline & $5-10$ & & & & & & & 1.54 & 2.52 \\
\hline & $10-20$ & & & & & & & 1.58 & 2.76 \\
\hline \multirow[t]{4}{*}{21} & $0-2.5$ & 4 & 0 & 6 & 40 & 48 & 2 & 1.60 & 2.66 \\
\hline & $2.5-5$ & 4 & 0 & 6 & 40 & 48 & 2 & 1.50 & 2.59 \\
\hline & $5-10$ & & & & & & & 1.46 & 2.44 \\
\hline & $10-20$ & & & & & & & 1.48 & 2.57 \\
\hline
\end{tabular}

$\mathrm{VCO}=$ very coarse sand $(1-2 \mathrm{~mm}), \mathrm{CO}=$ coarse sand $(1-0.5 \mathrm{~mm}), \mathrm{M}=$ medium sand $(0.5-0.25 \mathrm{~mm}), \mathrm{F}=$ fine sand $(0.25-0.1 \mathrm{~mm}), \mathrm{VF}=$ very fine sand $(0.1-0.05 \mathrm{~mm})$, $\mathrm{BD}=$ bulk density, $\mathrm{EC}=$ electrical conductivity

*6(PP) and 6(WP) are both 6-year age sites from two replicate ponds 
Appendix 2. Key to all 64-species identified in this study and which functional feeding group each belongs to.

\begin{tabular}{|c|c|c|}
\hline Species & Common Name (if applicable) & $\begin{array}{c}\text { Functional Feeding } \\
\text { Group }\end{array}$ \\
\hline Capitella capitata & Gallery worm & Deposit \\
\hline Laonice cirrata & & Deposit \\
\hline Notomastus (sp.?) & & Deposit \\
\hline Heteromastus filiformis & & Deposit \\
\hline Cistenides gouldii & Ice cream cone worm & Deposit \\
\hline Stenopleustes inermis & & Deposit, scavenger \\
\hline Nassarius vibex & Bruised nassa & Deposit \\
\hline Brada villosa & & Deposit \\
\hline Praxillella praetermissa & & Deposit \\
\hline Ophelina acuminata & & Deposit \\
\hline Pseudocyclops schminkei & & Deposit \\
\hline Pontoporeia femorata & & Deposit \\
\hline Praxillella gracilis & & Deposit, grazer \\
\hline Arenicola marina & & Deposit \\
\hline Leitoscoloplos fragilis & & Deposit \\
\hline Globosolembos smithi & & Deposit \\
\hline Crepidula plana & Eastern white slippersnail & Suspension \\
\hline Petricolaria pholadiformis & False angelwing & Suspension \\
\hline Siliqua costata & Atlantic razor & Suspension \\
\hline Gemma gemma & Amethyst gem clam & Suspension \\
\hline Cumingia tellinoides & & Suspension \\
\hline Aequipecten irradians & Bay scallop & Suspension \\
\hline Mya arenaria & Softshell clam & Suspension \\
\hline Anomia simplex & & Suspension, deposit \\
\hline Yoldia sapotilla & & Suspension \\
\hline Clymenella torquata & Bamboo worm & Suspension \\
\hline Mercenaria mercenaria & Quahog & Suspension \\
\hline Crepidula fornicata & Common slipper snail & Suspension \\
\hline Leptocheirus pinguis & & Suspension \\
\hline Alitta succinea & Clam worm & Scavenger \\
\hline Eteone trilineata & & Scavenger \\
\hline Psammonyx nobilis & & Scavenger \\
\hline Cotonopsis lafresnayi & & Scavenger \\
\hline Colus terraenovae & Ventricose whelk & Scavenger \\
\hline Glycera dibranchiata & & Scavenger \\
\hline Arabella iricolor & Opal worm & Scavenger \\
\hline Enchytraeus albidus & Whiteworm & Scavenger \\
\hline Amphiporeia virginiana & & Scavenger \\
\hline Oxydromus obscurus & Swift-footed worm & Scavenger \\
\hline Echinogammarus obtusatus & & Scavenger \\
\hline
\end{tabular}




\begin{tabular}{|c|c|c|}
\hline Species & Common Name (if applicable) & $\begin{array}{c}\text { Functional Feeding } \\
\text { Group }\end{array}$ \\
\hline Ptilohyale plumulosus & & Scavenger \\
\hline Goniada maculata & & Predator, deposit \\
\hline Actinothoe modesta & Thenarian burrowing anemone & Predator \\
\hline Lysianopsis alba & & Predator \\
\hline Microdeutopus gryllotalpa & Tube builder & Predator \\
\hline Boreotrophon truncatus & Bobtail trophon & Predator \\
\hline Epitonium rupicola & Brown-band wentletrap & Predator \\
\hline Aglaophamus verrilli & & Predator \\
\hline Paraexegone hebes & & Predator \\
\hline Syllis gracilis & & Predator \\
\hline Hypereteone lactea & & Predator \\
\hline Rhepoxynius epistomus & & Predator \\
\hline Dipolydora commensalis & & Interface \\
\hline Prionospio dubia & & Interface \\
\hline Ampharete lindstroemi & & Interface \\
\hline Corophium volutator & & Interface \\
\hline Marenzelleria viridis & & Interface \\
\hline Spiophanes bombyx & & Interface \\
\hline Chaetozone setosa & & Interface \\
\hline Bittiolum alternatum & & Grazers \\
\hline Littorina littorea & Common periwinkle & Grazer \\
\hline Gammarellus angulosus & & Grazer \\
\hline Odostomia & & Parasite \\
\hline Prunum roscidum & Seaboard marginella & Parasite \\
\hline
\end{tabular}


Appendix 3. Calculations from $\mathrm{N}$ and $\mathrm{C}$ losses from the oyster density experiment. All calculations reflect biodeposition data collected from near-market sized oysters (6 $\mathrm{cm})$.

Biodeposition addition/ $\mathbf{N}$ and $\mathbf{C}$ loss calculations:

Variables

Area $=0.04 \mathrm{~m}^{2}$

Time $=7$ days

Average stocking density $=500$ oysters $\mathrm{m}^{-2}$

High stocking density $=2000$ oysters $\mathrm{m}^{-2}$

Biodeposition rate $=0.11 \mathrm{~g}$ dry weight $(\mathrm{DW})$ oyster $^{-1}$ day $^{-1}$

$\mathrm{N}$ content in biodeposits $=0.014 \mathrm{~g} \mathrm{~N}$ biodeposits $^{-1}$

$\mathrm{C}$ content in biodeposits $=0.115 \mathrm{~g} \mathrm{C} \mathrm{g}$ biodeposits $^{-1}$

Average stocking density treatment:

- Amount of biodeposits added

$=$ Stocking density $*$ Area $*$ Biodeposition rate $*$ Time

$=500$ oysters $\mathrm{m}^{-2} * 0.04 \mathrm{~m}^{2} * 0.11 \mathrm{~g} \mathrm{DW}$ oyster ${ }^{-1}$ day $^{-1} * 7$ days

$=15.4 \mathrm{~g} \mathrm{DW}$ biodeposits

- Amount of $\mathrm{N}$ added in biodeposits

$=\underline{\text { Amount of biodeposits } * \mathrm{~N} \text { content in biodeposits }}$

Area

$=15.4 \mathrm{~g} \mathrm{DW}$ biodeposits $* 0.014 \mathrm{~g} \mathrm{~N}$ g biodeposits ${ }^{-1}$

$0.04 \mathrm{~m}^{2}$

$=5.4 \mathrm{~g} \mathrm{~N} \mathrm{~m}^{-2}$

- Amount of $\mathrm{C}$ added in biodeposits

$=\underline{\text { Amount of biodeposits } * \% \mathrm{C} \text { in biodeposits }}$

Area

$=15.4 \mathrm{~g} \mathrm{DW}$ biodeposits $* 0.115 \mathrm{~g} \mathrm{C} \mathrm{g}$ biodeposits $^{-1}$

$=44.3 \mathrm{~g} \mathrm{C} \mathrm{m}^{-2}$

High stocking density treatment:

- Amount of biodeposits added

$=$ Stocking density $*$ Area $*$ Biodeposition rate $*$ Time

$=2000$ oysters $\mathrm{m}^{-2} * 0.04 \mathrm{~m}^{2} * 0.11 \mathrm{~g} \mathrm{DW}$ oyster ${ }^{-1}$ day $^{-1} * 7$ days

$=61.6 \mathrm{~g} \mathrm{DW}$ biodeposits

- Amount of biodeposit $\mathrm{N}$ added

$=\underline{\text { Amount of biodeposits } * \% \mathrm{~N} \text { in biodeposits }}$

Area

$=\underline{61.6 \mathrm{~g} \mathrm{DW} \text { biodeposits } * 0.014 \mathrm{~g} \mathrm{~N} \text { g biodeposits }}{ }^{-1}$

$=21.55 \mathrm{~g} \mathrm{~N} \mathrm{~m}^{-2}$

$0.04 \mathrm{~m}^{2}$ 
- Amount of biodeposit $\mathrm{C}$ added

$$
\begin{aligned}
& =\underline{\text { Amount of biodeposits } * \% \mathrm{C} \text { in biodeposits }} \\
& \text { Area }
\end{aligned}
$$

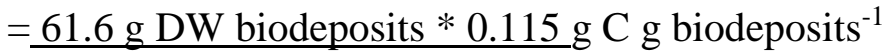

$$
\begin{aligned}
& =177.1 \mathrm{~g} \mathrm{C} \mathrm{m}^{-2}
\end{aligned}
$$

Expected increases in soil $\mathrm{N}$ and $\mathrm{C}$ levels one day after biodeposit application:

Variables

$\mathrm{N}$ content in biodeposits:

Average $=0.215 \mathrm{~g}$

High $=0.862 \mathrm{~g}$

$\mathrm{C}$ content in biodeposits:

Average $=1.77 \mathrm{~g}$

High $=7.08 \mathrm{~g}$

Average soil bulk density in upper $2 \mathrm{~cm}=1.3 \mathrm{~g} \mathrm{~cm}^{-3}$

Volume of soil $=800 \mathrm{~cm}^{3}$

Mass of soil affected:

$$
\begin{aligned}
& =\underline{\text { Bulk density }} \\
& =\frac{1.3 \mathrm{~g} \mathrm{~cm}^{-3}}{800 \mathrm{~cm}^{3}} \\
& =1040 \mathrm{~g} \mathrm{soil}^{-1}
\end{aligned}
$$

Average stocking density treatment:

- Increase in $\mathrm{N}$ level expected in soil after one day

$$
\begin{aligned}
& =\underline{\text { Biodeposit } \mathrm{N}} \\
& =\underline{\text { Mass of soil }} \\
& =\underline{0.215 \mathrm{~g} \mathrm{~N})} \\
& =0.0002 \mathrm{~g} \mathrm{soil}^{-1} \mathrm{~g} \mathrm{soil}^{-1} \\
& =0.2 \mathrm{~g} \mathrm{~N} \mathrm{~kg} \mathrm{soil}^{-1}
\end{aligned}
$$

- Increase in $\mathrm{C}$ level expected in soil after one day

$$
\begin{aligned}
& =\frac{\text { Biodeposit C }}{\text { Mass of soil }} \\
& =\frac{1.77 \mathrm{~g} \mathrm{C}}{1040 \mathrm{~g} \mathrm{soil}^{-1}} \\
& =0.0017 \mathrm{~g} \mathrm{~N} \mathrm{goil}^{-1} \\
& =1.7 \mathrm{~g} \mathrm{C} \mathrm{kg} \mathrm{soil}^{-1}
\end{aligned}
$$


High stocking density treatment:

- High treatment: Increase in $\mathrm{N}$ level expected in soil after one day $=\underline{\text { Biodeposit } \mathrm{N}}$

Mass of soil

$=\underline{0.862 \mathrm{~g} \mathrm{~N}}$

$1040 \mathrm{~g}$ soil

$=0.0008 \mathrm{~g} \mathrm{~N} \mathrm{~g} \mathrm{soil}^{-1}$

$=0.8 \mathrm{~g} \mathrm{~N} \mathrm{~kg} \mathrm{soil}{ }^{-1}$

- High treatment: Increase in C level expected in soil after one day

$=\underline{\text { Biodeposit } \mathrm{C}}$

Mass of soil

$=\underline{7.08 \mathrm{~g} \mathrm{C}}$

$1040 \mathrm{~g}$ soil

$=0.0068 \mathrm{~g} \mathrm{C} \mathrm{g} \mathrm{soil}^{-1}$

$=6.8 \mathrm{~g} \mathrm{C} \mathrm{kg} \mathrm{soil}^{-1}$ 


\section{BIBLIOGRAPHY}

Anderson, G. D. and Edwards, S.F. (1986). Protecting Rhode Island's coastal salt ponds: an economic assessment of down zoning. Coastal Zone Management Journal 14(1/2):67-91.

Ambrose, W.G. (1984). Role of predatory infauna in structuring marine soft-bottom communities. Marine Ecology Progress Series 17:109-115.

Asmus, H. and Asmus, R.M. (1993). Phytoplankton-mussel bed interactions in intertidal ecosystems. In: Bivalve Filter Feeders in Estuarine and Coastal Ecosystem Processes, R.F. Dame (ed.), Springer Verlag, Berlin. pp. 57-84.

Arakawa, K.Y., Kusuki, Y. and Kamigaki, M., (1971). Studies on biodeposition in oyster beds (I) - economic density of oyster culture. Venus 30:113-128 (In Japanese).

Bertness, M.D. (2007). Atlantic Shorelines: Natural History and Ecology. Princeton University Press, NJ. 431 pp. Print.

Bernard, F.R. (1974). Annual biodeposition and gross energy budget of mature Pacific oysters, Crassostrea gigas. Journal of Fisheries Research Board of Canada 31: 185-190.

Beutel, D. (2015). Aquaculture in Rhode Island: 2015 annual status report. Coastal resource Management Council. Web. Accessed: 06 Feb. 2017.

Bilyard, G.R. (1987). The value of benthic infauna in marine pollution monitoring studies. Marine Pollution Bulletin 18:581- 585.

Black, K.D. (2001). Environmental Impacts of Aquaculture. CRC Press, Boca Raton, FL.

Blakenship, K. (2004) Oysters will help trigger bay cleanup, but are no silver bullet. Bay Journal RSS. Web. Accessed: 06 Feb. 2017.

Boothroyd, J.C., Friedrich, N.E. and McGinn, S.R. (1985). Geology of microtidal coastal lagoons: Rhode Island. Marine Geology 63:35-76.

Boucher, G. and Boucher-Rodoni, R. (1988). In situ measurement of respiratory metabolism and nitrogen fluxes at the interface of oyster beds. Marine Ecology Progress Series 44:229-238.

Bousfield, E. L. (1973). Shallow-water Gammaridean Amphipoda of New England. Ithaca: Comstock Pub. Associates. Print. 
Bradley, M.P. and Stolt, M.H. (2003). Subaqueous soil-landscape relationships in a Rhode Island estuary: Soil Science Society of America Journal 67:487-1495.

Bradley. M.P. and Stolt, M.H. (2006). Landscape-level seagrass-sediment relations in a coastal lagoon. Aquatic Botany 84:121-128.

Brooks, R.P., Wardrop, D.H., Thornton, K.W., Whigham, D., Hershner, C., Brinson, M.M. and Shortle J.S. (eds.) (2006). Integration of ecological and socioeconomic indicators for estuaries and watersheds of the Atlantic Slope. Final Report to U.S. Environmental Protection Agency STAR Program, Agreement R-82868401, Washington, DC. Prepared by the Atlantic Slope Consortium, University Park, PA. 96 pp. + attachments (CD).

Byron, C., Bengtson, D., Costa-Pierce, B. and Calanni J. (2011). Integrating science into management: ecological carrying capacity of bivalve shellfish aquaculture. Marine Policy 35:363-370.

Byron, C., Link, J., Costa-Pierce, B., and Bengtson, D. (2011). Modeling ecological carry capacity of shellfish aquaculture in highly flushed temperate lagoons. Aquaculture 314:87-99.

Cerco, C.F. and Noel, M.R. (2007). Can oyster restoration reverse the cultural eutrophication in Chesapeake Bay? Estuaries and Coasts 30:331-343.

Clesceri, L.S., Greenberg, A.E. and Eaton, A.D. (eds.) (1998). Standard methods for the examination of water and wastewater $20^{\text {th }}$ ed. American Public Health Association. Washington, D.C.

Cloern, J.E. (1982). Does the benthos control phytoplankton biomass in south San Francisco Bay? Marine Ecology Progress Series 9:191-202.

Coen, L.D. and Grizzle, R.E.. (2007). The importance of habitat created by molluscan shellfish to managed species along the Atlantic coast of the United States. Atlantic States Marine Fisheries Commission, Habitat Management Series, Washington, DC. pp. 1-108.

Coen, L.D., Brumbaugh, R.D., Bushek, D., Grizzle, R.E., Luckenbach, M.W., Posey, M.H., Powers, S.P. and Tolley, S.G. (2007). Ecosystem services related to oyster restoration. Marine Ecology Progress Series. 341:303-307.

Dahlback, B. and Gunnarsson, L.A.H., (1981). Sedimentation and sulfate reduction under mussel culture. Marine Biology 63:269- 275.

Dame, R.F. (2012). Ecology of Marine Bivalves: An Ecosystem Approach 2nd ed. CRC Press, Boca Raton, FL. 
Dean, H.K. (2008). The use of polychaetes (Annelida) as indicator species of marine pollution: a review. Revista de Biologia Tropical 56(suppl 4):11-38.

De Grave, S., Moore, S.J. and Burnell, G. (1998). Changes in benthic macrofauna associated with intertidal oyster, Crassostrea gigas (Thunberg) culture. Journal of Shellfish Research 17:1137-1142.

Demas, G.P., Rabenhorst, M.C. and Stevenson, J.C. (1996). Subaqueous soils: a pedological approach to the study of shallow-water habitats. Estuaries 19: 229-237.

Demas. G.P. and Rabenhorst, M.C. (1999). Subaqueous soils: pedogenesis in a submersed environment. Soil Science Society of America Journal 63:12501257.

Dye, A. H. (2006). Is geomorphic zonation a useful predictor of patterns of benthic infauna in intermittent estuaries in New South Wales, Australia? Estuaries and Coasts 29:455-464.

Edwards, S.F. (1984). An analysis of the non-market benefits of protecting salt pond water quality in southern Rhode Island: an application of the hedonic price and contingent valuation techniques. M.S. Thesis. Department of Resource Economics, URI, Kingston, R.I.

Ermgassen, P.S., Spalding, M.D., Grizzle, R.E., and Brumbaugh, R.D. (2013). Quantifying the loss of a marine ecosystem service: filtration by the eastern oyster in US estuaries. Estuaries and Coasts 36 (1): 36-43.

Flach, E.C., (1992). The influence of 4 macrozoobenthic species on the abundance of the amphipod Corophium volutator on tidal flats of the Wadden Sea. Netherlands Journal of Sea Research 29:379-394.

French McCay D.P., Peterson, C.H., DeAlteris, J.T. and Catena, J.R. (2003). Restoration that targets function as opposed to structure: replacing lost bivalve production and filtration. Marine Ecology Progress Series 264:197-212.

Forrest, B.M., Creese, R.G. (2006). Benthic impacts of intertidal oyster culture, with consideration of taxonomic sufficiency. Environmental Monitoring and Assessment 112:159-176.

Forrest, B.M., Keeley, N.B., Hopkins, G.A., Webb, S.C., Clement, D.M. (2009) Bivalve aquaculture in estuaries: review and synthesis of oyster cultivation effects. Aquaculture 298:1-15.

Gaston, G.R. and Nasci, J. C. (1988). Trophic structure of macrobenthic communities in the Calcasieu estuary, Louisiana. Estuaries 11:201-211. 
Gee, G.W., and Bauder, J.W. (1986). Particle-size analysis. p. 383-411. In A. Klute (ed.) Methods of soil analysis. Part 1. 2nd ed. Agronomy Monograph 9. ASA and SSSA, Madison, WI.

Giles, H. and Pilditch, C.A. (2006). Effects of mussel (Perna canaliculus) biodeposit decomposition on benthic respiration and nutrient fluxes. Marine Biology 150:261-271.

Grabowski, J. H. (2004). Habitat complexity disrupts predator- prey interactions but not the trophic cascade on oyster reefs. Ecology 85:995-1.

Grabowski, J.H. and Peterson, C.H. (2007). Restoring oyster reefs to recover ecosystem services. In: Ecosystem Engineers-plants to protists, Cuddington, K., J.E. Byers, W.G. Wilson and A. Hastings (eds), Academic, Burlington. pp. 281-298.

Grant, J., Hatcher, A., Scott, D.B., Pocklington, P., Schafer, C.T., and Winters, G.V. (1995). A multidisciplinary approach to evaluating impacts of shellfish aquaculture on benthic communities. Estuaries 18:124-144.

Grant, J., Bugden, G., Horne, E., Archambault, M.C. and Carreau, M. (2007). Remote sensing of particle depletion by coastal suspension-feeders. Canadian Journal of Fisheries and Aquatic Sciences 64:387-390.

Grassle, J. P. and Grassle, J. E. (1976). Sibling species in the marine pollution indicator Capitella (Polychaeta). Science 192:567-569.

Grizzle, R.E. and Lutz, R.A.. (1989). A statistical model relating horizontal seston fluxes and bottom sediment characteristics to growth of Mercenaria mercenaria. Marine Biology 101:95-105.

Hauxwell, J., Cebrian, J., and Valiela, I. (2003). Eelgrass Zostera marina loss in temperate estuaries: relationship to land-derived nitrogen loads and effect of light limitation imposed by algae. Marine Ecology Progress Series 247:59-73.

Haven, D.S. and Morales-Alamo, R. (1966). Aspects of biodeposition by oysters and other invertebrate filter feeders. Limnology and Oceanography 11:487-498.

Higgins, C.B., Stephenson, K., and Brown, B.L. (2011). Nutrient bio assimilation capacity of aquacultured oysters: quantification of an ecosystem service. Journal of Environmental Quality 0:271-277.

Higgins, C.B., Tobias, C., Piehler, M.F., Smyth, A., Dame, R.F., Stephenson, K., and Brown, B.L. (2013). Effect of aquacultured oyster biodeposition on sediment $\mathrm{N}_{2}$ production in Chesapeake Bay. Marine Ecology Progress Series 473:7-27. 
Hines, C.M. and Brown, D.S. (2012). Review of Habitat Suitability Indices for the Eastern oyster and its importance in coastal habitat restoration. USDA NRCS Technical Report: 65-1535-11-11.

Hoellein, T. J. and Zarnoch, C. B. (2014). Effect of eastern oysters (Crassostrea virginica) on sediment carbon and nitrogen dynamics in an urban estuary. Ecological Applications 24:271-286.

Howarth, R., Chan, F., Conley, D.J., Garnier, J., Doney, S.C., Marino, R. and Billen, G. (2011). Coupled biogeochemical cycles: eutrophication and hypoxia in temperate estuaries and coastal marine ecosystems. Frontiers in Ecology and the Environment 9:18-26.

Humphries, A.T., Ayvazian, S.G., Carey, J.C., Hancock, B.T., Grabbert, S., Cobb, D., Strobel, C.J. and Fulweiler, R.W. (2016). Directly measured denitrification reveals oyster aquaculture and restored oyster reefs remove nitrogen at comparable high rates. Frontiers in Marine Science 3:74.

Jespersen, J.L. and Osher, L.J. (2007). Carbon storage in the soils of a mesotidal Gulf of Maine estuary. Soil Science Society of America Journal 71:372-379.

Kellogg, M.L., Smyth, A.R., Luckenbach, M.W., Carmichael, R.H., Brown, B.L., Cornwell, J.C., Piehler, M.F., Owens, M.S., Dalrymple, D.J., and Higgins, C.B. (2014). Use of oysters to mitigate eutrophication in coastal waters. Estuarine, Coastal and Shelf Science 151:156-168.

Kristensen, E. and Kostka, J.E. (2005). Macrofaunal burrows and irrigation in marine sediment: microbiological and biogeochemical interactions. In: Coastal and Estuarine Studies: Interactions between Macro- and Microorganisms in Marine Sediments (Kristensen, E., Haese, R.R and Kostka, J.E., eds), pp. 125-157, American Geophyiscal Union, Washington, D.C.

LaMontagne, M.G. and Valiela, I. (1995). Denitrification measured by a direct $\mathrm{N}_{2}$ flux method in sediments of Waquoit Bay, MA. Biogeochemistry 31:63-83.

Laverock, B., Gilbert, J., Tait, K., Osborn, A. M. and Widdicombe, S. (2011). Bioturbation: impact on the marine nitrogen cycle. Biochemical Society Transactions 39:315-320.

Loosanoff, V.L. and F.D., Tommers. (1948). Effect of suspended silt and other substances on rate of feeding of oysters. Science 107:69-70.

Magill, S.H., Thetmeyer, H. and Cromey, C.J. (2006). Settling velocity of fecal pellets of gilthead sea bream (Sparus aurata L.) and sea bass (Dicentrarchus labrax L.) and sensitivity analysis using measured data in deposition model. Aquaculture 251:295-305. 
Mallet, A.L., Carver, C.E. and Landry, T. (2006). Impact of suspended and offbottom Eastern oyster culture on the benthic environment in eastern Canada. Aquaculture 255:362-373.

Mattsson, J. and Lindén, O. (1983). Benthic macrofauna succession under mussels, Mytilus edulis L. (Bivalvia), cultured on hanging longlines. Sarsia 68:97-102.

McGlathery, K.J., Sundback, K. and Anderson, I.C. (2007). Eutrophication in shallow coastal bays and lagoons: The role of plants in the coastal filter. Marine Ecology Progress Series 348:1-18.

McKindsey, C.W., Thetmeyer, H., Landry, T. and Silvert, W. (2006). Review of recent carrying capacity models for bivalve culture and recommendations for research and management. Aquaculture 261:451-462.

Meadows, P.S., Reid, A., (1966). The behaviour of Corophium volutator (Crustacea: Amphipoda). Journal of Zoological Society of London 150:387-399.

Midwood, A.J. and Boutton, T.W. (1998). Soil carbonate decomposition by acid has little effect on 13C of organic matter. Soil Biology and Biochemistry 30:13011307.

Mitchell, P.H. (1917). Nutrition of oysters: Glycogen formation and storage. Bulletin of the United States Bureau of Fisheries 35:151-162.

Mitchell, I.M. (2006). In situ biodeposition rates of Pacific oysters (Crassostrea gigas) on a marine farm in southern Tasmania (Australia). Aquaculture 257: 194-203.

Möller, P. and Rosenberg, R. (1982). Production and abundance of the amphipod Corophium volutator on the west coast of Sweden. Netherlands Journal of Sea Research 16:127-140.

Newell, R.I.E. and Langdon, C.J. (1996). Mechanisms and physiology of larval and adult feeding. P 185- 229. In: V.S. Kennedy, R.I. Newell, and A.F. Eble, editors, The Eastern Oyster Crassostrea virginica. Maryland Sea Grant, College Park, MD.

Newell, R.I.E., Cornwell, J. and Owens, M.S. (2002). Influence of simulated bivalve biodeposition and microphytobenthos on sediment nitrogen dynamics: a laboratory study. Limnology and Oceanography 47:1367-1379.

Newell R.I.E., Fisher, T.R., Holyoke, R.R. and Cornwell, J.C. (2005). Influence of eastern oysters on $\mathrm{N}$ and $\mathrm{P}$ regeneration in Chesapeake Bay, USA. In: Dame R. and Olenin S. (eds.) The comparative roles of suspension feeders in ecosystems. Springer, Berlin, p. 93-12. 
Nixon, S.W. (1993). Nutrients and coastal waters, too much of a good thing? Oceanus $35: 38-47$.

Nixon, S.W. (1997). Prehistoric inputs and productivity in Narragansett Bay. Estuaries 20: 253-261.

Nixon, S.W. and Buckley, B.A. (2007). "Nitrogen Inputs to Rhode Island Coastal Salt Ponds - Too Much of a Good Thing". Special Collections Publications (Miscellaneous). Paper 11.

NRC (National Research Council) (2004) Non-native oysters in the Chesapeake Bay. National Research Council, National Academies Press, Washington, D.C.

Officer, C.B., Smayda, T.J. and Mann, R. (1982). Benthic filter feeding: a natural eutrophication control. Marine Ecology Progress Series 9:203-210.

Olsen, S. and Lee, V. (1991). A management plan for a coastal ecosystem: Rhode Island's salt pond region. In: Needham, B. (ed.), Case studies of coastal management: experience from the United States. CRC Publication 1001. Coastal Resources Center, URI, Narragansett, R.I. p. 57-69.

Paolucci, A. J. (2017). Assessing dynamic soil properties in southern New England using an ecological site framework. Master's Thesis, University of Rhode Island, Kingston, RI.

Payne, M.K. (2007). Landscape-level assessment of subaqueous soil and water quality in shallow embayments in southern New England. M.S. Thesis, Department of Natural Resources Science, University of Rhode Island, Kingston, RI.

Payne, M.K. and Turenne, J. (2009). Mapping the "new frontier" of soil survey: Rhode Island's MapCoast partnership. Soil Survey Horizons 50:86-89.

Pearson, T. H. and Rosenberg, R. (1978). Macrobenthic succession in relation to organic enrichment and pollution of the marine environment. Oceanography and Marine Biology: An Annual Review 16:229-311.

Pearson, T.H. and Stanley, S.O. (1979). Comparative measurement of the redox potential of marine sediments as a rapid means of assessing the effect of organic pollution. Marine Biology 53: 371-379.

Peterson, C.H., (1979). Predation, competitive exclusion, and diversity in the softsediment benthic communities of estuaries and lagoons. In: R.J. Livingston, (ed.), Ecological Processes in Coastal and Marine Systems, Plenium Press, NY, 223-264. 
Pfieffer-Herbert, A. (2007). Coastal ponds of Rhode Island: a case study for combining terrestrial, freshwater, and marine conservation priorities. A white paper prepared for The Nature Conservancy, Coastal Institute IGERT Program, University of Rhode Island.

Pollock, Leland W. (1998) A Practical Guide to the Marine Animals of Northeastern North America. New Brunswick, NJ: Rutgers UP. Print.

Powell, E.N., Hoffmann, E.E., Klinck, J.N. and Ray, S.M., (1992). Modeling oyster populations: A commentary on filtration rate. Is faster always better? Journal of Shellfish Research 11:387-398.

Prins, T.C., Smaal, A.C., and Dame, R.F. (1998). A review of the feedbacks between bivalve grazing and ecosystem processes. Aquatic Ecology 31:349-359.

Pruett, C.M., (2010). Interpretations of estuarine subaqueous soils: eelgrass restoration, carbon accounting, and heavy metal accumulation. M.S. Thesis, Department of Natural Resources Science, University of Rhode Island, Kingston, RI.

Rabenhorst, M.C. (2008). Protocol for using and interpreting IRIS tubes. Soil Survey Horizons 49:74-77.

Rabenhorst, M.C., Megonigal, J.P. and Keller, J. (2010). Synthetic iron oxides for documenting sulfide in marsh porewater. Soil Science Society of America Journal 74 (4):1383-1388.

Raffaelli, D., Limia, J., Hull, S. and Pont, S., (1991). Interactions between the amphipod Corophium volutator and macroalgal mats on estuarine mudflats. Journal of the Marine Biology Association of the United Kingdom. 71:899908.

Rhode Island Shellfish Management Plan (RISMP) (2014). The Rhode Island Shellfish Management Plan, Version II. http://www.rismp.org/. [accessed 01/26/2017].

Rice, M.A. (1992). The northern quahog: the biology of Mercenaria mercenaria. Rhode Island Sea Grant, RIU-B-92-001. ISBN 0-938412-33-7. 69 p.

Rice, M. A. and Pechenik, J.A. (1992). A review of the factors influencing the growth of the northern quahog, Mercenaria mercenaria Linnaeus, 1758. Journal of Shellfish Research 11:279-287.

Rice, M.A., Valliere, A. and Caporelli A. (2000). A review of shellfish restoration and management projects in Rhode Island. Journal of Shellfish Research 19:401408. 
Salisbury, A.R. (2010). Developing subaqueous soil interpretations for Rhode Island estuaries. M.S. thesis. Univ. of Rhode Island, Kingston, RI.

Sanders, H.L. (1969). Marine benthic diversity and the stability-time hypothesis. Brookhaven Symposia in Biology, 22:71-80.

Snelgrove, P.V.R., and C.A. Butman. (1994). Animal sediment relationships revisited: Cause versus effect. Oceanography and Marine Biology: Annual Review 32:111-177.

Snelgrove, P.V.R., (1998). The importance of marine sediment biodiversity in ecosystem processes. Ambio 26:578-583.

Snelgrove P.V.R., Grassle, J.F., Petrecca, R.F. and Stocks K.I. (2001). The role of colonization in establishing patterns of community composition and diversity in shallow-water sedimentary communities. Journal of Marine Research 59:813-831.

Soil Survey Laboratory Staff (2004). Soil survey laboratory methods manual. Soil survey investigation report no. 42 version 4.0. United States Department of Agriculture, Government Printing Office, Washington, D.C.

Soil Survey Staff (1999). Soil Taxonomy: A basic system of soil classification for making and interpreting soil surveys. $2^{\text {nd }}$ edition. USDA-NRCS, Agriculture Handbook. 436. U.S. Gov. Print Office, Washington, D.C.

Sornin, J.M., Feuillet, M., Héral, M. and Deslous-Paoli, J.M., (1983). Effet des biodépõts de l'huître Crassostrea gigas (Thunberg) sur l'accumulation de matiéres organiques dans les parcs du bassin de Marennes-Oléron. Journal of Molluscan Studies, Supplement 12A:185-197 (In French).

Steward, C.C., Nold, S.C., Ringelberg, D.B., White, D.C. and Lovell, C.R. (1996). Microbial biomass and community structures in the burrows of bromophenol producing and non-producing marine worms and surrounding sediments. Marine Ecology Progress Series 133:149-165.

Still, B.M. and Stolt, M.H. (2015). Subaqueous soils and coastal acidification: A hydropedology perspective with implications for calcifying organisms. Soil Science Society of America Journal 79:407-416.

Still, B.M. (2016). Using subaqueous soils data to manage coastal ecosystems: implications for bivalve recruitment, aquaculture, and restoration. Ph.D. Dissertation, Department of Natural Resources Science, University of Rhode Island, Kingston, RI. 
Torello, E. and Callender, E. (2013). Status and Trends: Water Quality in the Southern Rhode Island Coastal Lagoons. http://www.saltpondscoalition.org/ Accessed January 26, 2017.

Ulanowicz, R. E., and Tuttle, J. H. (1992). The trophic consequences of oyster stock rehabilitation in Chesapeake Bay. Estuaries 15:298-306.

Weiss, H.M. and Bennett, D.V. (1995). Marine Animals of Southern New England and New York: Identification Keys to Common Nearshore and Shallow Water Macrofauna. Hartford, CT: State Geological and Natural History Survey of CT, Department of Environmental Protection. Print.

WoRMS Editorial Board. (2017). World Register of Marine Species. Available from http://www.marinespecies.org at VLIZ. Accessed 2017-02-09. doi:10.14284/170.

Wilson, W.H. Jr. (1991). Competition and predation in marine soft-sediment communities. Annual Review of Ecology and Systematics 21:221-241. 